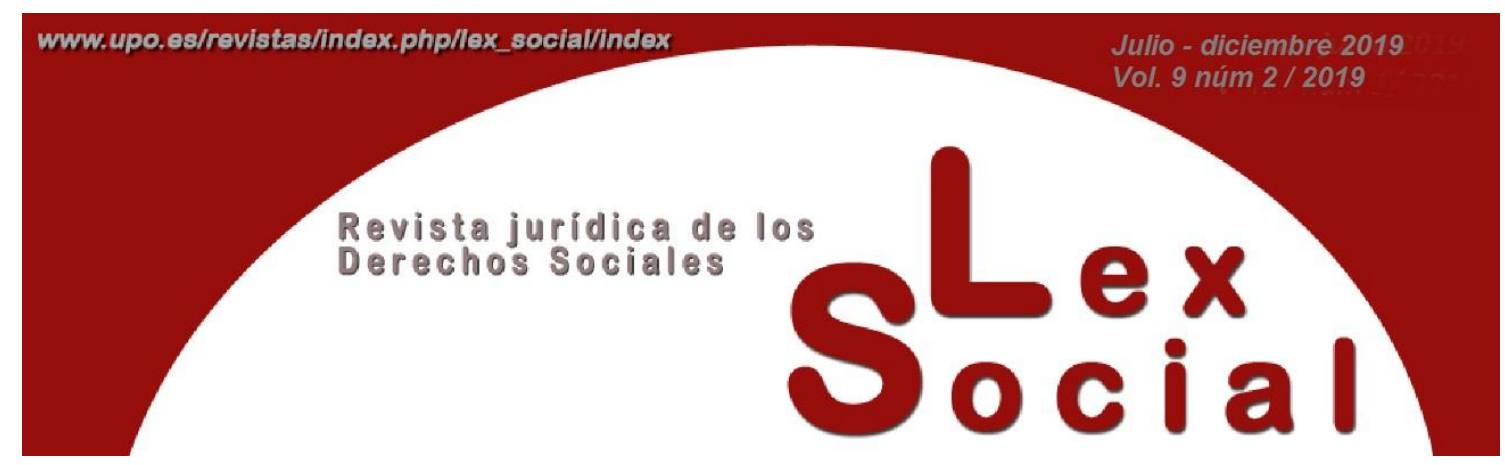

\title{
DE EMPLEADA DEL HOGAR A EMPRENDEDORA DEL HOGAR: EMPRENDIMIENTO COLECTIVO SOCIAL PARA UN AUTOEMPLEO DECENTE
}

\section{FROM HOME EMPLOYEE TO HOME ENTREPRENEUR: COLLECTIVE SOCIAL ENTREPRENEURSHIP FOR DECENT SELF-EMPLOYMENT}

\author{
MARTA GARCÍA MANDALONIZ \\ Departamento de derecho privado. Área de derecho mercantil. \\ Universidad Carlos III de Madrid
}

Artículo recibido el 17 de mayo de 2019

Artículo aceptado el 27 de mayo de 2019

\section{RESUMEN}

Bajo una mirada feminizada se plantea transformar el rol de la empleada doméstica. Se alienta su transformación en emprendedora doméstica para visibilizar y valorizar su papel en la sociedad. Se anima el emprendimiento para el empoderamiento. Se destacan motivaciones para un emprendimiento colectivo en la economía social. Se promueve el emprendimiento colectivo a través de una cooperativa de trabajo asociado o de una sociedad limitada laboral, como

\footnotetext{
${ }^{1}$ La autora (RESEARCH ID: C-1199-2015; ORCID ID: 0000-0003-0334-037X) quisiera manifestar que el presente trabajo (cerrado a 25 de abril de 2019) mantiene el tono discursivo y descriptivo, más que reflexivo, de la ponencia impartida, el 14 de noviembre de 2018, en la Facultad de Ciencias Sociales y Jurídicas de la Universidad Carlos III de Madrid, en el segundo seminario general sobre el trabajo doméstico, dirigido por la profesora M. ${ }^{a}$ G. QUINTERO LIMA, dentro del seminario permanente de trabajo doméstico del Laboratorio de Derecho Social del Instituto Universitario de Estudios de Género de la Universidad Carlos III de Madrid. Bajo el título con que se rubrica este trabajo y con un esquema y una visión explicativa o formativa, al contenido de la ponencia se incorporan las correspondientes notas a pie de página con las referencias legales y bibliográficas.
} 
entidades de economía social, para la consecución de un cambio en la (auto)percepción hacia la dignificación, así como para la adscripción al régimen general de la Seguridad Social con plena cobertura, también por desempleo. Se describe de modo conciso el régimen jurídico laboral, fiscal y societario de las sociedades cooperativas y de las sociedades limitadas laborales. Se comparan con otras sociedades mercantiles menos aptas o no aptas como método de creación de empleo y de autoempleo colectivo. Se promueve el emprendimiento colectivo y social como salida laboral. Se busca un (auto)empleo doméstico decente.

Palabras Clave: Trabajo doméstico, economía social, cooperativa, sociedad laboral.

\begin{abstract}
Under a feminized look, we propose to transform the role of the home employee. Its transformation into an entrepreneur is encouraged to visualize and value its role in society. Entrepreneurship for empowerment is encouraged. Motivations are highlighted for a collective entrepreneurship in the social economy. Collective entrepreneurship is promotes through a cooperative or a labor company, as social economy entities, to achieve a change in the self-perception towards dignity, as well as for the assignment to a general system of Social Security with full coverage, also for unemployment. This paper describes in a concise way the legal labor, fiscal and corporate legal regime of cooperative societies and labor companies. They are compared with other companies that are less apt or unfit as a vehicle for employment creation and collective self-employment. Collective and social entrepreneurship is promoted for a decent home job.
\end{abstract}

KEYWORDS: Domestic work, social economy, cooperative, labor company.

SUMARIO

1. TRANSFORMACIÓN PARA EL EMPODERAMIENTO ECONÓMICO DE LA EMPLEADA DEL HOGAR.

2. DE EMPLEADA DEL HOGAR A EMPRENDEDORA DEL HOGAR CON UN EMPRENDIMIENTO COLECTIVO Y SOCIAL.

3.EMPRENDIMIENTO COLECTIVO SOCIAL CON UNA COOPERATIVA.

3.1. Motivaciones para el emprendimiento colectivo social mediante una cooperativa. 
a. Motivaciones sociales. Motivaciones laborales. Motivaciones empresariales.

3.2. Cuestiones para el emprendimiento colectivo social mediante una cooperativa.

a. ¿Cuál es la legislación que aplicar?

b. ¿Cómo y dónde registrar?

c. ¿Quiénes son las socias y cuáles son sus derechos y deberes?

d. ¿Cuánto es el coste y cuál es la responsabilidad?

e. ¿Cómo organizar?

3.3. Cooperativa de trabajo asociado para la emprendedora del hogar.

3.4. Cooperativa de trabajo de iniciativa social para la emprendedora del hogar.

4.EMPRENDIMIENTO COLECTIVO SOCIAL CON UNA SOCIEDAD LIMITADA LABORAL.

4.1. ¿Cuál es la legislación que aplicar?

4.2. ¿Cómo y dónde registrar?

4.3. ¿Cuánto es el coste y cuál es la responsabilidad?

5. ¿EMPRENDIMIENTO COLECTIVO CON UNA SOCIEDAD DE RESPONSABILIDAD LIMITADA (DE FORMACIÓN SUCESIVA)?

5.1. ¿Emprendimiento colectivo con una comunidad de bienes de carácter mercantil?

5.2. ¿Emprendimiento colectivo con una sociedad mercantil personalista?

5.3. ¿Emprendimiento colectivo con una sociedad mercantil capitalista?

6. ¿EMPRENDIMIENTO COLECTIVO CON UNA PROPUESTA DE ENTIDAD DE RESPONSABILIDAD LIMITADA FLEXIBLE Y SIMPLIFICADA?

6.1 Con personalidad jurídica y responsabilidad limitada.2. Sin capital social mínimo legal.

7.-EMPODERAMIENTO ECONÓMICO DE LA EMPRENDEDORA DEL HOGAR PARA UN AUTOEMPLEO DECENTE.

BIBLIOGRAFÍA 


\section{TRANSFORMACIÓN PARA EL EMPODERAMIENTO ECONÓMICO DE LA EMPLEADA DEL HOGAR.}

Se abre esta disertación con una propuesta de transformación. La propuesta de transformación es para visibilizar, valorizar y dignificar a la empleada del hogar. La etiqueta con la que la asociación de servicio doméstico activo (SEDOAC) celebraba su décimo aniversario y el lema con el que rubricaba su primer congreso sobre el empleo del hogar y cuidados, el 1 y 2 de octubre de 2016, fue "visibilizar para transformar". Desde estas líneas introductorias complementamos y volteamos la expresión de "visibilizar para transformar" con la de "transformar para visibilizar". Se plantea transformar el rol desde la empleada doméstica hasta la emprendedora doméstica. Es un cambio de sentido para el empoderamiento económico de la (auto)empleada del hogar.

En esta exposición la visión y la posición serán en exclusiva femeninas. Se dirige la mirada hacia el empoderamiento de la mujer como objetivo buscado y apoyado por las Naciones Unidas. Desde el 18 de diciembre de 1979, en la Convención sobre la eliminación de todas las formas de discriminación contra la mujer ${ }^{2}$; luego en su Protocolo facultativo, aprobado por la Resolución 54/4 de la Asamblea General, de 6 de octubre de 19993; y en Resoluciones posteriores, como la 67/202 4 , de 21 de diciembre de 2012, se expresa el empoderamiento femenino y se recuerda el papel impulsor de la mujer en la iniciativa empresarial.

El empoderamiento femenino ha de figurar entre las prioridades de los Estados para derrumbar las desigualdades que padecen las mujeres en materia económica, a fin de estimular su destacado lugar en el desarrollo sostenible y en el crecimiento económico ${ }^{5}$. Un crecimiento económico que ha de ser inclusivo, implicando y promoviendo la igualdad de oportunidades entre los hombres y las mujeres en el acceso a los recursos económicos y al mercado. "Un criterio inclusivo para promover el espíritu empresarial"6. La prioridad ha de ser el empoderamiento económico de la mujer para crear y desarrollar empresas ${ }^{7}$. Un empoderamiento económico femenino para pasar del

\footnotetext{
${ }^{2}$ Con entrada en vigor como Tratado internacional el 3 de septiembre de 1981.

${ }^{3}$ En vigor desde el 22 de diciembre de 2000.

${ }^{4}$ Resolución 67/202, de 21 de diciembre de 2012, de iniciativa empresarial para el desarrollo (A/RES/67/202).

${ }^{5}$ Conforme a los párrafos 172 a 174 del Anexo de la Nota de la Secretaría de la Comisión de Naciones Unidas para el Derecho Mercantil Internacional (CNUDMI), de 10 de abril de 2018, del proyecto de Guía Legislativa sobre los principios fundamentales de la inscripción registral de empresas; según tuvimos ocasión de citar, a estos efectos, en: GARCÍA MANDALONIZ, M.: "Fomentando la formalización del emprendimiento femenino con un registro electrónico de empresas y una entidad de responsabilidad limitada simplificada", en BLÁZQUEZ AGUDO, E. M.: Los ODS como punto de partida para el fomento de la calidad del empleo femenino. Madrid: Dykinson, 2018, pp. 138 y ss.

${ }^{6}$ En las palabras literales de la Secretaría de la CNUDMI reflejadas en el párrafo 174, p. 58, del Anexo de la Nota que acaba de ser reseñado en la nota a pie de página anterior.

${ }^{7}$ Como señala la Secretaría de la CNUDMI en la Nota citada supra en las dos notas a pie de página previas.
} 
sector informal (o no reglamentado) ${ }^{8}$ en el que se desenvuelve buena parte de la prestación de los servicios domésticos al sector formal (o reglamentado) de la economía ${ }^{9}$. Pasar de operar en la economía sumergida a la economía formalizada conlleva "importantes efectos de empoderamiento" que se aprecian especialmente en el caso de las mujeres ${ }^{10}$. En los denominados "derechos empresariales", como conjunto de derechos para operar en el mercado, se incluye el derecho a crear una empresa en el sector formal de la economía sin discriminación y con eliminación de cualquier interdicción legal ${ }^{11}$. En consecuencia, aboga la Comisión de las Naciones Unidas para el Derecho Mercantil Internacional (CNUDMI) -en un documento sobre la creación de un entorno jurídico propicio para el funcionamiento de las pymes- por esos derechos empresariales, con el ánimo de empoderar a las personas menos favorecidas, entre ellas las mujeres, para que establezcan empresas como fórmula de autoempleo y de empleo para "ganarse la vida"12.

\section{DE EMPLEADA DEL HOGAR A EMPRENDEDORA DEL HOGAR CON UN EMPRENDIMIENTO COLECTIVO Y SOCIAL.}

Es emprendimiento para el empoderamiento. No solo puede ser emprendimiento individual sino colectivo. Conviene, a los efectos del empoderamiento de las trabajadoras del hogar, más el emprendimiento colectivo que el individual. Más que como una mera suma de individualidades, el emprendimiento colectivo acrecienta su empoderamiento económico. Si a ese carácter colectivo sumamos el rasgo social, el emprendimiento entra a formar parte de la economía social. La economía social no rechaza el mercado, sino que se inserta en él mediante la participación y la cooperación para la ayuda mutua y la solidaridad. La economía social forma parte de un desarrollo alternativo a largo plazo para la sostenibilidad.

La economía social es definida, en el artículo 2 de la Ley $5 / 2011^{13}$ que la regula, como el "conjunto de las actividades económicas y empresariales, que en el ámbito privado llevan a cabo aquellas entidades que, de conformidad con los principios orientadores de la economía social, persiguen el interés colectivo de sus integrantes, el interés general económico o social, o ambos".

\footnotetext{
${ }^{8}$ Indican los párrafos 17 y siguientes del documento de la CNUDMI sobre la creación de un entorno jurídico propicio para el funcionamiento de las pymes (A/CN.9/941) que el concepto de "informalidad" no es uniforme. Aunque se trata de una actividad "no reglamentada" no tiene por qué ser ilícita y puede deberse a una necesidad económica, a las elevadas exigencias y costes, a la falta de información o a la falta de oportunidades (párrafos 11, 20, 22 y 25, pp. 8-9).

${ }^{9}$ Ídem.

${ }^{10}$ Según resaltara el citado documento de la CNUDMI sobre el entorno jurídico propicio para las pymes, en los párrafos 28 y siguientes, pp. 10 y siguientes, y, en especial, p. 12.

${ }^{11}$ En la definición del párrafo 4 del documento citado supra en la nota a pie de página previa.

12 De conformidad nuevamente con el Documento de la CNUDMI sobre la creación de un entorno jurídico propicio para el funcionamiento de las pymes (párrafo 4, p. 4).

${ }^{13} \mathrm{BOE} \mathrm{n}^{\circ}$ 76, 30 marzo 2011 (BOE-A-2011-5708). 
Los principios orientadores de la economía social son, en virtud del artículo 4 de esta ley: primero, la primacía de las personas y los fines sociales sobre el capital; segundo, la aplicación de los resultados obtenidos en la actividad económica en función del trabajo y de los servicios realizados por los socios; tercero, la promoción de la solidaridad interna para un compromiso con el desarrollo local, con la igualdad de oportunidades entre los hombres y las mujeres, con la inserción de las personas en riesgo de exclusión social, con la generación de empleo estable [y, añadimos, decente], con la conciliación de la vida personal, familiar y laboral, y con la sostenibilidad; y, cuarto y último, la independencia respecto de los poderes públicos. Estos principios orientadores se sustentan en los valores inspiradores de la economía social, en general, y del cooperativismo, en particular. Son principios para la consecución de valores. Los valores son la cooperación y la solidaridad, y "constituyen la esencia, el alma y el espíritu del cooperativismo" ". Son "el ADN de las formas asociativas cooperativas"15.

Las entidades que forman parte de la economía social son, conforme al artículo 5.1 de la nombrada ley, "las cooperativas, las mutualidades, las fundaciones y las asociaciones que lleven a cabo actividad económica". Lo son, en particular, las cooperativas, las sociedades laborales, las mutualidades, las fundaciones y asociaciones con actividad económica, las empresas de inserción, los centros especiales de empleo, las cofradías de pescadores, las sociedades agrarias de transformación y, en general, cualesquiera otras entidades singulares que, creadas por normas específicas, que cumplan los mencionados principios orientadores. De este extenso listado de entidades de economía social, interesa destacar, a los efectos del colectivo de mujeres que desempeñan las tareas del hogar y de los cuidados, las cooperativas y las sociedades laborales. Ambas formas jurídicas son aptas e idóneas para el emprendimiento colectivo social en el sector del trabajo doméstico.

\section{3.-EMPRENDIMIENTO COLECTIVO SOCIAL CON UNA COOPERATIVA.}

Hablar de las empleadas del hogar como socias de las entidades de economía social no es una utopía sino una realidad. Múltiples y conocidos ejemplos de emprendimiento colectivo social a través de cooperativas constituidas e integradas por empleadas del hogar se hallan en distintas regiones de la geografía nacional ${ }^{16}$.

\footnotetext{
${ }^{14}$ Como bien expresara MARTÍNEZ ETXEBERRÍA, G.: La aplicación efectiva de los valores cooperativos. Madrid: Dykinson, 2018, pág. 21.

${ }^{15}$ Ibidem, p. 19.

${ }^{16}$ Una noticia sobre la constitución de cooperativas en el servicio doméstico se publicó en el Diario Información, el 14 de junio de 2012, bajo el título: "Un grupo de mujeres crea la primera cooperativa de empleadas de hogar". Su contenido (extractado) fue el siguiente: "Un grupo de unas quince mujeres, además de un equipo asesor, ha constituido en Elche la "Cooperativa Valenciana de Empleadas de Hogar del Levante", como así se denomina la primera sociedad cooperativa que surge en la ciudad y, probablemente, en la provincia". "El servicio [doméstico] lo ofrece la cooperativa. La cooperativa es la que se encarga de todo, ya que es una empresa de trabajadoras. La persona que necesite a una empleada de hogar podrá pedirlo a la cooperativa". Aparte, como consta en la página web de "Abierto Hasta el Amanecer, S. Coop." (AHA) (http://abiertomadrid.coop/wordpress/ [última consulta: 25 abril 2019]) esta ISSN: 2174-6419 Lex Social, vol. 9, núm. 2 (2019)
} 


\subsection{Motivaciones para el emprendimiento colectivo social mediante una cooperativa.}

Sin ánimo de exhaustividad, las razones destacadas para el autoempleo colectivo social cooperativo en el servicio doméstico son tanto de carácter general, propias del cooperativismo, como de carácter particular, características de la regulación especial laboral y de la Seguridad Social ${ }^{17}$.

\section{a. Motivaciones sociales.}

Motivación usual para la elección del cooperativismo es la inclusión dentro de un modelo económico-social ${ }^{18}$ de producción de bienes y servicios alternativo al clásico modelo económico. Este modelo productivo alternativo tiene la capacidad de detectar y solucionar dificultades y necesidades sociales y económicas, como el desempleo, el empleo informal, el empleo no decente o el empleo de baja calidad. En tendencia imparable se camina hacia la transformación del clásico modelo económico y su sustitución progresiva por un nuevo modelo económico sostenible donde los aspectos sociales en unión indisoluble con los económicos adquieren un protagonismo relevante para la creación y el mantenimiento de un empleo de calidad y estable.

Este nuevo formato económico-social viene acompañado por el uso de una variada terminología 19 . Así, se viene hablando de la "economía social", de la "economía solidaria", "economía colaborativa", "economía compartida" o "economía circular". De entre las nombradas expresiones escogemos en la presente investigación la de "economía social". Con pretensión de solidaridad y sostenibilidad, de igualdad y responsabilidad $^{20}$, la economía social busca implantar y desplegar la "creación de

cooperativa de trabajo de iniciativa social se constituyó en el año 2002 y se domicilió en Madrid y "uno de los proyectos que desarrolla es el asesoramiento en procesos de constitución de empresas cooperativas, en especial, cooperativas de trabajo en el servicio doméstico". Desde su constitución" ha asesorado a muchas empleadas del hogar y ha ayudado a la creación de cooperativas de trabajo asociado". Más ejemplos pululan por la geografía nacional. A saber: "Work-Lan Bizcaia", que, gracias al asesoramiento recibido de "Abierto Hasta el Amanecer, S. Coop.", ha venido impulsando el proceso de constitución de cooperativas integradas por las empleadas del hogar, poniéndose a disposición de las interesadas para aclarar dudas o ampliar información. Asimismo, "Victoria S. Servicios del Hogar S. Coop.", con sede en la Comunidad de Madrid, que ofrece asistencia y servicios sociales para niños y jóvenes con discapacidad y ancianos en centros no residenciales. También, "Comala, Cooperativa de iniciativa social de servicios a domicilio"; o "TIEBEL, Cooperativa de iniciativa social", domiciliada en Zaragoza, que desde el año 1993 se dedica a la "prestación de servicios [...] a la comunidad en los ámbitos de la limpieza profesional, la formación ocupacional y los servicios sociales". Son "estas actividades el vehículo principal para alcanzar su objeto social: la generación de puestos de trabajo, preferentemente para la mujer".

17 Fuente: página web de "Abierto hasta el amanecer, sociedad cooperativa": http://abiertomadrid.coop/wordpress/;

cooperativas/ (última consulta: 25 abril 2019)

18 Ídem.

${ }^{19}$ Vid. MORILLO, M.: "Dos monedas sociales para favorecer una economía alternativa”. El País Digital, 3 abril 2018.

${ }^{20}$ Vid. CHAVES ÁVILA, R.; MONZÓN CAMPOS, J. L.: "La economía social ante los paradigmas económicos emergentes: innovación social, economía colaborativa, economía circular, responsabilidad ISSN: 2174-6419 Lex Social, vol. 9, núm. 2 (2019) 
empleo inclusivo, decente y de calidad", en el cúmulo de adjetivos que para el empleo procedente de las entidades de economía social expresara el prólogo y el primer objetivo específico de la Estrategia Española de la Economía Social 2017-2020²1; continuadora del programa de fomento e impulso de la economía social 2015-2016 que tuvo su razón de ser en la Ley de Economía Social de 2011. La apuesta por un empleo inclusivo de calidad es la apuesta por el empleo proveniente de la economía social ${ }^{22}$. Una economía social configurada como "modelo de crecimiento económico sostenible y solidario" 23 , para la cohesión social y territorial, y regida por los principios cooperativos de participación, colaboración, solidaridad, autonomía, igualdad o democracia.

Presidiendo el principio democrático la gestión y el control de una cooperativa, el sistema cooperativo tiene su epicentro en las socias-trabajadoras. Como partícipes y decisoras, las mujeres, al tiempo que trabajadoras del hogar, son socias de la cooperativa; y desde la posición de socias atisban un cambio en "la percepción social de la labor doméstica y [en su propia] auto-percepción" ${ }^{24}$. Esta transformación de la percepción y de la auto-percepción las valoriza, visibiliza ${ }^{25}$, dignifica y, en definitiva, empodera.

\section{b. Motivaciones laborales.}

A la mutación de la (auto)percepción hacia la dignificación se añade el cambio en el régimen de la Seguridad Social. Como socias-trabajadoras de una cooperativa se les permite la adscripción y la equiparación plena de derechos al régimen general de la Seguridad Social, sin las especialidades (a nuestro parecer, discriminaciones) con las que cuentan en el sistema especial para "empleados" [rectius, en la praxis, “empleadas"] ${ }^{26}$ del hogar ${ }^{27}$.

social empresarial, economía del bien común, empresa social y economía solidaria”. Revista de Economía Pública, Social y Cooperativa, $\mathrm{n}^{\circ}$ 93, agosto 2018, págs. 5-50

${ }^{21}$ Elaborada por la Dirección General del Trabajo Autónomo, de la Economía Social y de la Responsabilidad Social de las Empresas del Ministerio de Empleo y Seguridad Social y publicada en el BOE $\mathrm{n}^{\circ}$ 69, 20 marzo 2018 (BOE-A-2018-3857).

${ }^{22}$ Sobre las características del empleo en la economía social, consúltense las páginas 14 y siguientes de la Estrategia Española de la Economía Social 2017-2020.

${ }^{23}$ En palabras del prólogo de la reseñada Estrategia Española de la Economía Social 2017-2010.

${ }^{24}$ https://vallecas.com/empleadas-de-hogar-construyendo-cooperativas/

(última consulta: 25 abril 2019).

${ }^{25}$ En ídem se expresa gráficamente del siguiente modo: "pasar de invisible a empresaria".

${ }^{26}$ Conforme a los datos de 2007 de la Organización Internacional del Trabajo (OIT), los servicios del trabajo doméstico son desempeñados fundamentalmente por mujeres, según se recoge en: SANDE PÉREZ-BEDMAR, M. DE, "La relación laboral especial de los empleados de hogar: aspectos laborales y de Seguridad Social". Revista Jurídica de la Universidad Autónoma de Madrid, nº 23, 2011-I, p. 154. En este artículo doctrinal al citado dato mundial se añade uno nacional: "En España, las mujeres representan el $91 \%$ de los que trabajan en el sector".

${ }^{27}$ Fuente: "Abierto hasta el amanecer, sociedad cooperativa" y "Work-Lan Bizcaia" (en este último caso, con datos de 20 de enero de 2012). 
Fue en la disposición adicional primera de la (derogada) Ley 32/1984, de 2 de agosto $^{28}$, cuando por primera vez se estableció la habilitación para que el Gobierno regulara el régimen jurídico de las relaciones laborales de carácter especial, entre ellas, las de los servicios del hogar ${ }^{29}$. En virtud de esa habilitación reglamentaria, su primera regulación -recogida en el Real Decreto 1424/1985 ${ }^{30}$ - mantuvo y confirmó la especialidad. Tras su derogación, es el Real Decreto 1620/2011, de 14 de noviembre, el que regula la relación laboral de carácter especial del servicio del hogar familiar ${ }^{31}$. Y en virtud y con el alcance de la disposición adicional 39 de la Ley 27/2011 ${ }^{32}$, desde el 1 de enero de 2012, el régimen de la Seguridad Social de las empleadas de hogar se integra en el régimen general, pero como un sistema específico para este colectivo de mujeres. Con el Real Decreto-Ley 29/2012, de 28 de diciembre, de mejora de la gestión y protección social en el sistema especial para las empleadas de hogar ${ }^{33}$, se incorpora alguna revisión, pero se conserva la especialidad del sistema.

La especialidad conduce a la particularidad de la acción protectora. Tratando de resumir esa particularidad en el sentido en el que para informar lo resume el Ministerio de Trabajo, Migraciones y Seguridad Social ${ }^{34}$, se ha de hacer notar que, en caso de incapacidad temporal por contingencias comunes, sea enfermedad común o accidente no laboral, la empleada del hogar tiene derecho a percibir el subsidio a contar desde el noveno (antes desde el vigésimo noveno) ${ }^{35}$ día de baja, con abono de la prestación a cargo de la empleadora desde el cuarto al octavo día ${ }^{36}$, sin que hubiera en la regulación

\footnotetext{
${ }^{28}$ Ley 32/1984, de 2 de agosto, sobre modificación de determinados artículos de la Ley 8/1980, de 10 de marzo, del Estatuto de los Trabajadores (BOE n ${ }^{\circ}$ 186, 4 agosto 1984 [BOE-A-1984-17436]); derogada por el Real Decreto Legislativo 1/1995, de 24 de marzo (BOE no 75, 29 marzo 1995 [BOE-A-19957730]); a su vez, derogado por el vigente Real Decreto Legislativo 2/2015, de 23 de octubre, por el que se aprueba el Texto Refundido de la Ley del Estatuto de los Trabajadores (BOE n ${ }^{\circ} 255,24$ octubre 2015 [BOE-A-2015-11430]).

${ }^{29}$ En el tenor literal de la Disposición adicional primera: "El Gobierno en el plazo máximo de doce meses contados a partir de la entrada en vigor de la presente Ley, regulará el régimen jurídico de las relaciones laborales de carácter especial previstas en el artículo 2, punto 1, de la Ley 8/1980, de 10 de marzo del Estatuto de los Trabajadores". El artículo 2, punto 1, letra b) se refería como relación laboral especial: "La del servicio del hogar familiar".

${ }^{30}$ BOE no $^{\circ} 193,13$ agosto 1985 (BOE-A-1985-17108).

${ }^{31} \mathrm{BOE} \mathrm{n}^{\mathrm{o}} 277,17$ noviembre 2011 (BOE-A-2011-17975).

${ }^{32} \mathrm{BOE} \mathrm{n}^{\circ}$ 184, 2 agosto 2011 (BOE-A-2011-13242).

${ }^{33} \mathrm{BOE} \mathrm{n}^{\mathrm{o}} 314,31$ diciembre 2012 (BOE-A-2012-15764).

${ }^{34} \mathrm{La}$ especialidad de la acción protectora se resume en la página web del Ministerio de Trabajo, Migraciones y Seguridad Social: http://www.mitramiss.gob.es/es/portada/serviciohogar/nuevaregulacion/segsocial/index.htm (última consulta: 25 abril 2019).

35 Antes, con el artículo 30 del Decreto 2346/1969, de 25 de septiembre (BOE n 247, 15 octubre 1969 [BOE-A-1969-1187]): “en los casos de enfermedad y accidente [la] prestación económica [por incapacidad laboral transitoria] se comenza[ba] a percibir desde el vigésimo noveno día, contado a partir de la fecha en que se inició la enfermedad o se produjo el accidente".

${ }^{36}$ Disposición adicional $39^{\mathrm{a}} .3$, en su letra b), de la Ley 27/2011, en los siguientes términos que transcribimos: "Con efectos desde el 1 de enero de 2012, el subsidio por incapacidad temporal, en caso de enfermedad común o accidente no laboral, se abonará a partir del noveno día de la baja en el trabajo, estando a cargo del empleador el abono de la prestación al trabajador desde los días cuarto al octavo de la citada baja, ambos inclusive".
} 
anterior obligación de abono alguno a su cargo ${ }^{37}$. El pago de ese subsidio se hace de forma directa por la entidad gestora correspondiente (INSS) ${ }^{38}$, sin que proceda el pago delegado $^{39}$. Se cotiza para la percepción de una pensión de jubilación, pero ha habido veto para acogerse a una jubilación parcial, especial ${ }^{40}$ o anticipada ${ }^{41}$; y no ha habido, desde 2012 a 2018, integración de lagunas para la base reguladora, en tanto solo se han tomado en consideración "los períodos realmente cotizados" 42 . Durante ese período temporal, no fueron, en consecuencia, aplicables las reglas para la integración de lagunas contempladas en el artículo 209.1.b) del texto refundido de la Ley general de la Seguridad Social (TRLGSS) ${ }^{43}$, aprobado por el Real Decreto Legislativo 8/2015 ${ }^{44}$. Además de pensión de jubilación en los términos restrictivos temporales antedichos, hay pensión por incapacidad permanente derivada de contingencias comunes, pero de similar modo a lo ocurrido con la pensión de jubilación tampoco rigieron las reglas para la integración de lagunas para la base reguladora de esta otra pensión ${ }^{45}$ del artículo 197.4 de aquel texto refundido ${ }^{46}$. También hay protección por contingencias profesionales ${ }^{47}$, enfermedad profesional o accidente laboral, pero no resulta aplicable el régimen de responsabilidad que respecto de las prestaciones contiene el artículo 126 del citado texto refundido. Asimismo, hay derecho a la prestación contributiva por maternidad, bien que en la práctica pueda tener en ocasiones poca virtualidad ${ }^{48}$. No hay derecho, en cambio, a la prestación por desempleo ${ }^{49}$.

Esta última exclusión provoca discriminación. Discriminación por abolir para una plena protección, sin los lastres históricos, económicos o burocráticos que dieron lugar, en el origen, a la especialidad del régimen de Seguridad Social de las empleadas del hogar y que, a nuestro parecer ${ }^{50}$, no encuentran, en la actualidad, justificación para la

${ }^{37}$ Como nos recuerda SANDE PÉREZ-BEDMAR, M. DE: “La relación laboral especial...”, op. cit., p. 161.

${ }^{38}$ Oficina del Instituto Nacional de la Seguridad Social correspondiente al domicilio.

${ }^{39}$ Apartado 3.c) de la Disposición adicional 39a de la Ley 27/2011.

${ }^{40}$ Jubilación especial a los 64 años, para el fomento del empleo, desaparecida desde el 1 de enero de 2013, salvo en los supuestos excepcionales legales que se pueden consultar en: http://www.segsocial.es/wps/portal/wss/internet/Trabajadores/PrestacionesPensionesTrabajadores/10963/28393/28400 (última consulta: 25 abril 2019).

41 Jubilación anticipada regulada en sus distintos supuestos (por razón de la actividad, en caso de discapacidad, por causa no imputable al trabajador o por voluntad del interesado) en los artículos 206 a 208 del Texto Refundido de la Ley General de la Seguridad Social (TRLGSS).

${ }^{42}$ En los términos de la Disposición adicional 39ª $3^{\circ}$, letra d) de la Ley 27/2011, para el período de 2012 a 2018.

${ }^{43}$ En la anterior Ley General de la Seguridad Social, de 1994, se contemplaban en el artículo 162.1.2.

44 Texto Refundido aprobado por el Real Decreto Legislativo 8/2015, de 30 de octubre (BOE n $^{\circ} 261,31$ octubre 2015 [BOE-A-2015-11724]).

${ }^{45}$ Nuevamente, de acuerdo con la Disposición adicional 39a $.3^{\circ}$, letra d) de la Ley 27/2011.

${ }^{46}$ En el anterior, de 1994, era en el artículo 140.4 donde se recogían.

${ }^{47}$ Disposición adicional 53 TRLGSS, en los términos reglamentarios recogidos en el Real Decreto 1596/2011, de 4 de noviembre (BOE n ${ }^{\circ}$ 290, 2 diciembre 2011 [BOE-A-2011-18914]).

${ }^{48}$ En SANDE PÉREZ-BEDMAR, M. DE: "La relación laboral especial...", op. cit., p. 154, queda reflejado que el $45 \%$ de las trabajadoras domésticas no goza en la práctica de permisos por maternidad, como tampoco de un día fijo para el descanso semanal.

${ }^{49}$ Disposición adicional 39a.3.f) de la Ley 27/2011.

${ }^{50}$ Previamente en el parecer de: FEDERACIÓN DE SERVICIOS DE LA UGT: Características, problemática y propuestas de reforma del sector del servicio doméstico en España. Noviembre 2005. ISSN: 2174-6419 Lex Social, vol. 9, núm. 2 (2019) 
conservación de tal especialización ${ }^{51}$. Una plena protección deseamos con una equiparación también plena. Integración en el régimen general con homogenización para tender hacia la unidad del sistema de Seguridad Social ${ }^{52}$, bajo el entendimiento que planteara la recomendación sexta del Pacto de Toledo en torno a que la existencia de regímenes especiales provoca dificultad para la sostenibilidad. Aunque en línea con esta tendencia unificadora existe una habilitación legal expresa al Gobierno para la ampliación al sector de servicios domésticos y de cuidados de la protección por desempleo ${ }^{53}$, aún no se ha extendido. Sin extensión no hay integración ni equiparación, hay diversidad y no homogeneidad. Por la extensión de los derechos de protección aboga el Convenio 189 de la Organización Internacional del Trabajo (OIT), de 16 de junio de $2011^{54}$, sobre el trabajo decente para las trabajadoras domésticas; sin ratificación en nuestro país, con ratificación que seguimos esperando.

Las empleadas del hogar continúan integradas en el sistema especial del régimen general, sin previsión de desempleo, cuando sean contratadas directamente por los titulares del hogar familiar ${ }^{55}$. Pero, cuando la contratación de las tareas domésticas se realiza no a través de una persona física sino de una persona jurídica, con formato societario civil o mercantil, aunque el objeto siga siendo la prestación de tareas domésticas, el alta de la trabajadora se hará sin especialidad en el régimen general de la Seguridad Social por cuenta de la empresa, en virtud de la Disposición adicional $17^{\mathrm{a}}$ de la Ley $27 / 2011^{56}$. No habiendo especialidad si la contratación es a través de una persona jurídica -como persona jurídica es, por ejemplo, una cooperativa-, habrá equiparación total de derechos, también del derecho al desempleo. De constituir junto con otras trabajadoras domésticas una nueva cooperativa o de integrarse con otras en una cooperativa ya constituida, a efectos del derecho de la Seguridad Social, la empleada del hogar podría ser trabajadora por cuenta ajena con integración plena en el régimen general $^{57}$, sin especialidad, sin discriminación. Los detalles de la opción de la

\footnotetext{
${ }^{51}$ A las razones históricas, económicas o de gestión burocrática de la singularidad de este régimen aludiría: SENDIN BLÁZQUEZ, A.: El régimen especial de la Seguridad Social de empleados de hogar: cuestiones sobre su integración en el régimen general de la misma. Ministerio de Trabajo y Asuntos Sociales, diciembre 2006, pp. 53 y ss. En el parecer de SANDE PÉREZ-BEDMAR, M. DE, "La relación laboral especial...", op. cit., p. 163, sí "tiene justificación desde el punto de vista de lo económico y lo organizativo, siendo el lugar de prestación de servicios el hogar familiar”. También por el mantenimiento de la especialidad se decantaría, por ejemplo: LÓPEZ GANDÍA, J., Las relaciones laborales especiales. Albacete: Bomarzo, 2008, pp. 99 y ss.

52 Ibidem, pp. 59-63. Acerca de "la tendencia a la unidad que debe presidir la ordenación del sistema de la Seguridad Social”, léase el artículo 10.5 TRLGSS.

${ }^{53}$ En SANDE PÉREZ-BEDMAR, M. DE, "La relación laboral especial...”, op. cit., p. 163, se enfatiza que "queda expresamente abierta la posibilidad de que en el futuro se contemplen medidas de protección para estos trabajadores en caso de desempleo".

${ }_{54}$ Adoptado en la 100a reunión de la OIT, en Ginebra, el 16 de junio de 2011.

${ }_{55}^{55}$ Artículo 250.1.2 TRLGSS.

56 También el artículo 2 (“exclusiones") del Real Decreto 1620/2011.

${ }^{57}$ En la página web de "Work-Lan Bizcaia", http://www.work-lan.com/2012/01/las-cooperativas-detrabajo-asociado-de.html (última consulta: 25 abril 2019), se refleja que: "La creación de cooperativas de servicios para el hogar es una alternativa a esta situación que ofrece ventajas para las trabajadoras. En su calidad de socias-trabajadoras, logran la equiparación total de derechos al régimen general de Seguridad Social".
} 
cooperativa por el régimen general (no especial) de la Seguridad Social habrá ocasión de enumerarlos al describir los caracteres principales de la cooperativa de trabajo asociado, como clase de cooperativa óptima para la prestación de servicios del hogar a terceras personas. De momento, interesa resaltar que a una trabajadora dedicada a las tareas del hogar que fuese una socia trabajadora de una cooperativa de trabajo asociado, le serían de aplicación las reglas del régimen general de la Seguridad Social (o, en su caso, del régimen de autónomos, en función de cuál hubiera sido la elección de la cooperativa) en idénticos términos, condiciones y prestaciones que al resto de los colectivos incluidos en él; salvo la correspondiente al FOGASA, por la que no cotizarían.

\section{c. Motivaciones empresariales.}

Para hallar motivaciones empresariales, que unir a las laborales y sociales, habría que acentuar la condición de socia de la sociedad cooperativa de la trabajadora del hogar. Como socia asumiría riesgo y de responsabilidad (limitada a la aportación al capital social), a cambio del goce de autonomía e independencia. En la ecuación empresarial planteada, las mujeres cuidadoras del hogar asumirían la propiedad y la organización de la producción en común bajo criterios democráticos y de ayuda mutua. Siendo la finalidad última la ayuda mutua entre las socias, las cooperativas en las que se integrarían serían sociedades de base mutualista ${ }^{58}$, rigiendo la doble cualidad de socias y usuarias-trabajadoras.

La sociedad mutualista por excelencia es la sociedad cooperativa dentro de la economía social $^{59}$. Teniendo el concepto de mutualidad un apoyo constitucional en el artículo 129.2 de la Constitución española, sus claves principales son la adopción de acuerdos por mayoría, la autoorganización, la variabilidad del capital y la persecución de la satisfacción del interés común.

La clave del principio mayoritario para la aprobación de los acuerdos sociales se especifica en el ejercicio de los derechos "por cabezas": una persona, un voto ${ }^{60}$. El sistema de votos por cabezas cuenta con excepciones legales, como la del voto plural o fraccionado en las cooperativas que tienen distintas modalidades de socias, cuando se considere necesario para el mantenimiento de las proporciones establecidas en los estatutos para cada tipo de socias, en relación al derecho de voto en la asamblea

\footnotetext{
58 O "empresas mutualísticas", en la terminología de VICENT CHULIÁ, F. en: "Las empresas mutualistas y el derecho mercantil en el ordenamiento español". Revista Crítica de Derecho Inmobiliario, año 52, no 512, enero-febrero 1976, pp. 69-136; "Las empresas mutualísticas", en BROSETA PONT, M.: Manual de derecho mercantil. $4^{\mathrm{a}}$ ed., Madrid: Tecnos, 1977.

${ }^{59}$ Vid., ad ex., ALONSO SOTO, F.: "Las cooperativas como protagonistas de la economía social". Estudios cooperativos, no 53, 1985, pp. 91-120; VICENT CHULIÁ, F.: "Cooperativismo y economía social”. Boletín de la Dirección General de Cooperativas del Ministerio de Trabajo y Seguridad Social, noviembre 1984, pp. 13-53.

${ }^{60}$ Artículo 26.1 Ley 27/1999, de 16 de julio, de Cooperativas (BOE no 170, 17 julio 1999 [BOE-A-199915681]): "En la Asamblea General cada socio tendrá un voto". 
general $^{61}$. Las excepciones legales cuentan con límites legales: la suma de los votos plurales no podrá alcanzar la mitad del número de socias, y las socias titulares de los votos plurales podrán renunciar en cualquier votación a su voto plural, ejerciendo un único voto. Los estatutos, además, habrán de regular los supuestos imperativos de voto igualitario $^{62}$. Salvo en las excepciones previstas, como la regla general es que en la asamblea general cada socia cuenta con un voto ${ }^{63}$, rige el principio democrático, con igualdad de derechos y deberes.

También se concreta en ese principio básico de la democracia, tanto en la gestión como en el control, la clave del auto-organicismo. En la administración de la cooperativa participan las socias. Está presente, consecuentemente, la doble cualidad de socias y administradoras, aunque con admisión de excepción. La excepción se manifiesta en la posible existencia de administradoras no socias, aun con limitaciones cuantitativas (hasta un tercio de las administradoras en la ley estatal ${ }^{64}$; o hasta un cuarto en la regional de la Comunidad de Madrid ${ }^{65}$ ).

Por otra parte, la clave de la variabilidad del capital social, como regla general, entronca con el principio de puerta abierta, en tanto es libre la entrada y la salida de socias, bien que con admisión de restricción. Para la entrada, la restricción es el cumplimiento de los requisitos de admisión. Para la salida, la restricción es el preaviso (máximo anual) al consejo rector o la posibilidad de un compromiso estatutario de permanencia (máximo quinquenal $)^{66}$.

La clave final de la satisfacción de las necesidades sociales y económicas comunes es propia de las sociedades mutualísticas y, entre ellas, de las paradigmáticas cooperativas. Pueden obtener ganancias económicas. De obtenerse, está presente el principio de no reparto de dividendos activos. Pueden, en cambio, repartirse intereses por las aportaciones obligatorias al capital, si así hubiera quedado reflejado en los estatutos, y por las aportaciones voluntarias, en los términos de remuneración o con el procedimiento para su determinación que estableciera el acuerdo de admisión ${ }^{67}$. Además, puede haber distribución de los excedentes del ejercicio y de los beneficios extra-cooperativos y extraordinarios, en forma de retornos cooperativos a las socias, con proporcionalidad a la actividad desarrollada en la cooperativa, en vez de en función de sus aportaciones al capital ${ }^{68}$. La satisfacción de las necesidades comunes también se entiende como la realización entre las socias de la actividad social de intercambio de

\footnotetext{
${ }^{61}$ Según indica el artículo 26.3 de la Ley de Cooperativas estatal.

${ }^{62}$ Apartado séptimo del artículo 26.

63 Artículo 26.1.

${ }^{64}$ Art. 34.2.

65 Artículo 41.1. $2^{\circ}$ de la Ley 4/1999, de 30 de marzo, de Cooperativas de la Comunidad de Madrid (BOCM n 87, 14 abril 1999).

${ }^{66}$ Artículo 17.3 Ley 27/1999.

${ }^{67}$ Artículo 48.1 Ley 27/1999. En ningún caso, la remuneración de las aportaciones excederá en más de seis puntos del interés legal del dinero, en función de los prescrito por el artículo 48.2.

${ }^{68}$ Artículo 58, apartados tercero y cuarto, de la Ley de Cooperativas estatal. 
productos o servicios de forma principal, casi exclusiva, aunque no excluyente, en tanto cabe realizar con terceros las actividades cooperativizadas, aun con necesidad de previsión estatutaria ${ }^{69}$. Pero, precisamente es la producción de bienes o servicios para terceros a través de la prestación de trabajo por parte de las socias trabajadoras el rasgo que define legalmente a la clase de cooperativa que a nuestros efectos más interesa: la de trabajo asociado ${ }^{70}$. Aun con esta precisión para este tipo de cooperativa, en suma, la finalidad última de una cooperativa es satisfacer el interés colectivo de sus miembros, sin perjuicio de que pueda realizar actividades con terceros y pueda conseguir beneficios económicos. Y sin perjuicio también de que determinadas cooperativas puedan ser calificadas propiamente como sociedades cooperativas sin ánimo de lucro por gestionar servicios de interés colectivo o de titularidad pública o por ejecutar actividades económicas para la integración laboral de las personas que sufran exclusión social $^{71}$, como las cooperativas de (trabajo asociado) de iniciativa social que también aquí interesan.

Con este elenco de claves y bajo la guía de los principios mutualistas ${ }^{72}$-expresados en Manchester, en 1995, en la Declaración sobre la identidad y los principios cooperativos de la Alianza Cooperativa Internacional- de ingreso y salida voluntarios, de gestión democrática, de participación económica, de autonomía e independencia, de interés por la comunidad, además de formación ${ }^{73}$ e información, e inter-cooperación ${ }^{74}$, se

\footnotetext{
${ }^{69}$ Conforme al artículo 4.1 de la Ley estatal: "sólo cuando lo prevean los Estatutos, y en las condiciones y con las limitaciones que establece la [propia] Ley, así como otras Leyes de carácter sectorial que les sean de aplicación".

${ }^{70}$ Artículo 80.1 Ley 27/1999.

${ }^{71}$ En los términos de la Disposición adicional primera de la Ley de Cooperativas estatal.

${ }^{72}$ La Ley 27/1999 no enumera en su articulado los principios cooperativos, pero su Exposición de Motivos indica en el párrafo cuarto que tienen cabida en esta normativa "como elementos indispensables para construir una empresa viable con la que los socios se identifican al apreciar en ella la realización de un proyecto económico que garantice su empleo". Expresamente están, en cambio, recogidos, aunque no definidos, en el artículo 3 del Real Decreto-Legislativo 2/2015, de 15 de mayo, del Consell, por el que se aprueba el texto refundido de la Ley de Cooperativas de la Comunitat Valenciana (DOGV n ${ }^{\circ} 7529,20$ mayo 2015), para la interpretación y aplicación de esta ley y de sus normas de desarrollo. Se enumeran en dicho artículo 3 los siete siguientes principios: primero, adhesión voluntaria y abierta; segundo: gestión democrática por parte de los socios; tercero, participación económica de los socios; cuarto, autonomía e independencia; quinto, educación, formación e información; sexto, cooperación entre cooperativas; y, séptimo y último, interés por la comunidad. También se expresan en el artículo 4 de la Ley 14/2011, de 23 de diciembre, de Sociedades Cooperativas Andaluzas (BOJA no 255, 31 diciembre 2011) diez principios cooperativos: libre adhesión y baja voluntaria; estructura, gestión y control democráticos; igualdad de derechos y obligaciones; participación en la actividad cooperativizada; autonomía e independencia; formación e información; cooperación empresarial; fomento del empleo estable y de calidad; igualdad de género; sostenibilidad empresarial y medioambiental; y compromiso con la comunidad. Igualmente, la legislación de las Islas Baleares contiene un precepto (el $\mathrm{n}^{\mathrm{o}} 3$ ) para la enumeración de los principios cooperativos. Otras normativas regionales, como la madrileña o la riojana, prefieren hacer una remisión general a los principios cooperativos formulados por la Alianza Cooperativa Internacional (en sus respectivos artículos 1.2).

${ }^{73}$ Principio de educación-formación cooperativa y difusión del espíritu cooperativo.

${ }^{74} \mathrm{El}$ fomento de la cooperación cooperativista y, en concreto, de las relaciones inter-cooperativas se efectúa por integración con base en el principio de coordinación (si de cooperativas de segundo grado o cooperativas de cooperativas se trata) o en el de subordinación (en el supuesto de la articulación de grupos cooperativos). 
desenvuelve la cooperativa como "verdadera institución socioeconómica" 75 . Según manifiesta la Exposición de Motivos de la Ley 27/1999, de 16 de julio, de cooperativas $^{76}$, estos principios tienen cabida en nuestra legislación como elementos indispensables para construir una empresa viable con la que los socios se identifiquen ${ }^{77}$. Los valores éticos de la solidaridad, la democracia, la igualdad ${ }^{78}$ y la vocación social inspiran los principios cooperativos. En atención a las claves, a los principios y a los valores cooperativos, las sociedades cooperativas persiguen una finalidad social realizando una actividad empresarial ${ }^{79}$. Con una caracterización societaria (especial) ${ }^{80}$,

75 En la expresión que emplea al inicio la Exposición de Motivos de la Ley estatal de Cooperativas.
${ }^{76}$ Se insiste que se publicó en el BOE $n^{\circ} 170,17$ julio 1999 (BOE-A-1999-15681). Publicaciones
tempranas destacadas en torno a esta Ley estatal fueron, por ejemplo, las siguientes: LLOBREGAT
HURTADO, M. ${ }^{a}$ L.: "Régimen económico de las sociedades cooperativas en el marco de la nueva Ley
General de Cooperativas de 16 de julio de 1999 (BOE de 17 de julio)". Revista de Derecho de
Sociedades, no 13,1999, pp. 190-228; MORILLAS JARILLO, M. J.: "La nueva regulación estatal de las
sociedades cooperativas". Derecho de los Negocios, no 111 , año 10,1999 , pp. 1-13.
77 Como indicábamos en: GARCÍA MANDALONIZ, M.: "Naturaleza jurídica del microcrédito y
caracterización societaria de las instituciones microfinancieras". Cuadernos de la Cátedra Garrigues, vol.
.3, junio 2015, pp. 96-99. ${ }^{78} \mathrm{Al}$ principio cooperativo de la igualdad se ha referido la jurisprudencia en distintas ocasiones. Así, en las sentencias de la Sala primera del Tribunal Supremo de 26 de enero de 1983, 20 de marzo de 1986, 19 de mayo de 1987 o 5 de abril de 2005. Extractos de estas sentencias podrá hallar el lector interesado en: MORILLAS JARILLO, M. ${ }^{a}$ J.: Las sociedades cooperativas. Madrid: Iustel, 2008, p. 119.

${ }^{79}$ Vid. GARCÍA MANDALONIZ, M.: "Naturaleza jurídica...”, op. cit., p. 97.

${ }^{80}$ Dilatada ha sido la discusión doctrinal surgida en torno a la naturaleza jurídica de la cooperativa. De manera monográfica, en la literatura mercantil, consúltense los siguientes estudios publicados en los años sesenta y setenta del siglo pasado: GÓMEZ CALERO, J.: "Sobre la "mercantilidad" de las cooperativas". Revista de Derecho Mercantil, no 137, julio-septiembre 1975; SÁNCHEZ CALERO, F.: "Los conceptos de sociedad y de empresa en la Ley de Cooperativas", en Libro homenaje a Ramón M. ${ }^{a}$. Roca Sastre. Vol. III, Madrid: Junta de Decanos de los Colegios Notariales, 1977; SÁNCHEZ CALERO, F.; OLIVENCIA, M.: "Relaciones del régimen jurídico de las sociedades mercantiles y de las sociedades cooperativas", en El cooperativismo de la coyuntura española actual. Anales de moral social y económica. Vol. 6, Madrid: Centro de Estudios Sociales de la Santa Cruz del Valle de los Caídos, 1964. Con la vigente Ley de Cooperativas -en el concepto que de "cooperativa" recoge el artículo 1.1 ("La cooperativa es una sociedad constituida por personas que se asocian, en régimen de libre adhesión y baja voluntaria, para la realización de actividades empresariales, encaminadas a satisfacer sus necesidades y aspiraciones económicas y sociales, con estructura y funcionamiento democrático")- se difuminan las dudas que hubieran podido subsistir, al señalar expresamente este precepto que la cooperativa es una sociedad que realiza actividades empresariales. En palabras de BROSETA PONT, M.; MARTÍNEZ SANZ, F.: Manual de Derecho mercantil. 25 ed., Vol. I, 2018, p. 663, esta "evidente aproximación" hacia el concepto de sociedad mercantil queda reforzada cuando el artículo 1.2 permite que "cualquier actividad económica lícita podrá ser organizada y desarrollada mediante una sociedad constituida al amparo de la presente Ley" y el artículo 4 admite que puedan llevarse a cabo actividades cooperativizadas con terceros no socios, aun con condiciones y limitaciones (Ídem). Pese al hecho de que las Comunidades Autónomas hayan asumido competencias legislativas en materia de cooperativas -que, en principio, chocaría con su calificación como sociedades mercantiles, a tenor del artículo 149.1. $6^{\circ}$ de la Constitución española que reserva al Estado la competencia exclusiva sobre la legislación mercantil-, en palabras de MORILLAS JARILLO, M. ${ }^{a}$ J.; FELIÚ REY, M. I.: Curso de cooperativas. $3^{\mathrm{a}}$ ed., Madrid: Tecnos, 2018, p. 112: "La cooperativa es $[\ldots]$ una sociedad mercantil especial". Esta calificación se ve confirmada con el artículo 211-1.1. f) del Anteproyecto de Código mercantil donde de manera expresa se indica que son sociedades mercantiles las sociedades cooperativas. Para finalizar se ha de hacer notar que el contenido de esta nota a pie de página se corresponde con el de la nota a pie $\mathrm{n}^{\circ} 75$ de nuestro estudio: GARCÍA MANDALONIZ, M.: "Naturaleza jurídica...", op. cit., pp. 96-99 y, en especial, p. 98; donde por descuido olvidamos nombrar el Manual de derecho mercantil de BROSETA PONT y MARTÍNEZ SANZ. 
la cooperativa realiza actividades empresariales encaminadas a satisfacer las necesidades y aspiraciones económicas y sociales de sus miembros ${ }^{81}$.

\subsection{Cuestiones para el emprendimiento colectivo social mediante una cooperativa.}

Una vez conocidos los valores y los principios inspiradores, la cuestión para preguntar a cada trabajadora del hogar es si decidiría sumarse al movimiento del emprendimiento cooperativo. A aquellas trabajadoras cuya respuesta inicial fuera afirmativa o, cuando menos, no fuera negativa pudieran surgirles dispares interrogantes: ¿cuál?, ¿cómo?, ¿dónde?, ¿quién?, ¿cuánto? En este texto podrán hallar algunas contestaciones, aunque solo podrán ser enunciadas con suma brevedad, a modo de breve guía o de escueto manual, por ser la descripción y no la reflexión la sistemática del presente documento elaborado con fines informativos y formativos ${ }^{82}$.

a. ¿Cuál es la legislación que aplicar?

Ante el primer interrogante de cuál será la legislación que aplicar ${ }^{83}$, la respuesta variará. La variación estará en función de la región donde vaya a desarrollarse la actividad empresarial. La legislación autonómica ${ }^{84}$ será la legislación aplicable. La Ley 27/1999,

${ }^{81}$ Vid. GARCÍA MANDALONIZ, M.: "Naturaleza jurídica...”, op. cit., pp. 96-99.

${ }^{82} \mathrm{Si}$ el lector interesado quisiera encontrar información detallada, que a los efectos de este trabajo explicativo no es posible incluir aquí, podría acudir al siguiente manual especializado: MORILLAS JARILLO, M. a J.; FELIÚ REY, M.: Curso..., op. cit., 803 pp. De manera más sucinta, también a este otro anterior: MORILLAS JARILLO, M. ${ }^{\mathrm{a}}$ J.: Las sociedades cooperativas..., op. cit., 108 pp., más jurisprudencia y legislación.

${ }^{83}$ Sobre la legislación estatal (en coordinación con la autonómica), resultan recomendables, además de los manuales referenciados en la nota a pie de página previa, la siguiente bibliografía más específica y breve: LLOBREGAT HURTADO, M. ${ }^{a}$ L.: "Régimen económico...”, op. cit., pp. 190-228; MORILLAS JARILLO, M. ${ }^{\text {a } ~ J .: ~ " L a ~ n u e v a ~ r e g u l a c i o ́ n ~ e s t a t a l ~ . . . ", ~ o p . ~ c i t ., ~ p p . ~ 1-13 ; ~ M O R I L L A S ~ J A R I L L O, ~ M . ~}{ }^{a}$ J.: "El ámbito de aplicación de las leyes de sociedades cooperativas", en Derecho de sociedades: libro homenaje al profesor Fernando Sánchez Calero. McGraw-Hill Interamericana de España, vol. 4, 2002, pp. 48134852, VICENT CHULIÁ, F.: “La Ley 27/1999, de 16 de julio, de cooperativas estatal”, Revista General de Derecho, $\mathrm{n}^{\circ} 663,1999$, pp. 14561-14584.

${ }^{84}$ El extenso listado de la legislación de corte autonómica es el que sigue: Ley del Principado de Asturias 4/2010, de 29 de junio, de cooperativas. Ley 4/1993, de 24 de junio, de Cooperativas de Euskadi, modificada por la Ley 1/2000, de 29 de junio; por la Ley 8/2006, de 1 de diciembre; o por la Ley 6/2008, de 25 de junio (con un Proyecto de Ley de 2016 ); y acompañada por la Ley 6/2008, de 25 de junio, de la Sociedad Cooperativa pequeña de Euskadi. Decreto Legislativo 2/2014, de 29 de agosto, por el que se aprueba el Texto Refundido de la Ley de Cooperativas de Aragón (derogatorio de la Ley 9/1998, de 22 de diciembre). Decreto Legislativo 2/2015, de 15 de mayo, del Consell, por el que se aprueba el Texto Refundido de la Ley de Cooperativas de la Comunitat Valenciana. Ley 12/2015, de 9 de julio, de Cooperativas de la Generalitat de Catalunya. Ley 9/2018, de 30 de octubre, de Sociedades Cooperativas de Extremadura (derogatoria de la Ley 2/1998, de 26 de marzo) y Ley 8/2006, de 23 de diciembre, de Sociedades Cooperativas Especiales de Extremadura. Ley 5/1998, de 18 de diciembre, de Cooperativas de Galicia, revisada por las Leyes 14/2004, 2/2007, 18/2008, 14/2011, 6/2016 y 5/2017. Ley 4/1999, de 30 de marzo, de Cooperativas de la Comunidad de Madrid. Ley 4/2001, de 2 de julio, de Cooperativas de La Rioja. Ley 4/2002, de 11 de abril, de Cooperativas de la Comunidad de Castilla y León; modificada por la Ley 2/2018, de 18 de junio. Ley 1/2003, de 20 de marzo, de Cooperativas de las Illes Balears, modificada por la Ley 7/2005, por la Ley 5/2011 y por la Ley 4/2019. Ley 8/2006, de 16 de noviembre, de Sociedades Cooperativas, de la Región de Murcia. Ley Foral 14/2006, de 11 de diciembre, de Cooperativas de Navarra. Ley 11/2010, de 4 de noviembre, de Cooperativas de Castilla-La Mancha. Ley ISSN: 2174-6419 Lex Social, vol. 9, núm. 2 (2019) 
de ámbito estatal ${ }^{85}$, solo se aplicará directamente (aunque en todas las regiones supletoriamente ${ }^{86}$ ), además de en las Islas Canarias ${ }^{87}$, en las ciudades autónomas de Ceuta y Melilla. Aunque su ámbito de aplicación sea muy reducido ${ }^{88}$, hay que anotar que también será aplicable de forma directa a aquellas cooperativas que ejerzan la actividad cooperativizada en el territorio de varias Comunidades Autónomas, excepto si en una de ellas lo desarrollasen con carácter principal. La duda de qué significa el desarrollo con carácter principal en un territorio la resuelve el artículo 2.2 del Reglamento del registro de sociedades cooperativas, aprobado por el Real Decreto $136 / 2002$, en el siguiente sentido ${ }^{89}$ : cuando la actividad sea superior en un territorio que en el conjunto de los demás territorios en los que opera la cooperativa ${ }^{90}$. En el momento inicial de la constitución, esta circunstancia se deducirá de los estatutos. Si a lo largo de la vida societaria variaran tales circunstancias habría que variar el fuero registral. La acreditación de la variación podría hacerse por certificación de la sociedad indicando el lugar donde se realiza efectivamente la actividad cooperativizada principal, por modificación de los estatutos o por cualquier medio de prueba válido en derecho.

\section{b. ¿Cómo y dónde registrar?}

Una vez conocida cuál es la ley aplicable, autonómica o estatal, podrán aparecer las siguientes palabras interrogativas: "cómo" y "dónde" registrar. Para la adquisición por parte de la cooperativa de personalidad jurídica se exige escritura pública (salvo excepción legal autonómica) ${ }^{91}$ e inscripción registral. La escritura pública (con las

14/2011, de 23 de diciembre, de Sociedades Cooperativas Andaluzas; revisada por la Ley 5/2018, de 19 de junio. Y Ley 6/2013, de 6 de noviembre, de Cooperativas de Cantabria.

${ }^{85}$ Se recuerda, una vez más, que la Ley estatal es la Ley 27/1999, de 16 de julio; derogatoria de la Ley 3/1987, de 2 de abril, General de Cooperativas, que había sido publicada en el BOE n ${ }^{\circ} 84,8$ abril 1987 (BOE-A-1987-8685). Respecto de ambas normativas, la vigente y la derogada, BROSETA PONT, M.; MARTÍNEZ SANZ, F.: Manual..., op. cit., p. 662, criticaron que su régimen jurídico sea tan "minucioso" porque es y ha sido "probablemente excesivo para lo que es su ámbito real de aplicación".

${ }^{86}$ En virtud del artículo 149.3 in fine de la Constitución española cuando indica que: "el derecho estatal será, en todo caso, supletorio al derecho de las Comunidades Autónomas".

${ }^{87}$ Sin normativa cooperativa se encuentran las Islas Canarias; rigiéndose, a estos efectos, por la Ley estatal. No obstante, la Comunidad Autónoma de Canarias tiene competencia exclusiva en la materia en virtud del artículo 30.24 de la Ley orgánica 10/1982, de 10 de agosto; que fue revisada por la Ley orgánica 4/1996, de 30 de diciembre, de reforma de su Estatuto de Autonomía. Un Proyecto de Ley de Sociedades Cooperativas de Canarias se publicó en el Boletín Oficial de Canarias (BOC) de 4 de noviembre de 2013. Más reciente es el Anteproyecto de Ley de 7 de marzo de 2018; sometido a información pública por anuncio de 25 de abril de 2018; y con Dictamen preceptivo 6/2018 del Consejo Económico y Social de Canarias.

${ }^{88}$ En BROSETA PONT, M.; MARTÍNEZ SANZ, F.: Manual..., op. cit., pp. 662-663.

${ }^{89}$ Artículo 2.2 del Real Decreto 136/2002, de 1 de febrero, por el que se aprueba el Reglamento del Registro de Sociedades Cooperativas (BOE no 40, 15 febrero 2002 [BOE-A-2002-3019]).

${ }^{90}$ El artículo 3.2 de la Ley de Cooperativas de Castilla-La Mancha especifica que para averiguar si la actividad cooperativizada se realiza con carácter principal en un territorio (en este caso, el castellano manchego) hay que tomar "en consideración su volumen en cada ejercicio económico, la ubicación real de los centros de trabajo o de las explotaciones de los socios, o cualesquiera otros índices reveladores de la efectiva actividad".

${ }^{91}$ Como excepción legal autonómica, hay que mencionar la del artículo 9.1 de la Ley de Sociedades Cooperativas Andaluzas porque no exige en todo caso la escritura pública de constitución: "Las sociedades cooperativas deberán inscribir el acta de la asamblea constituyente y demás documentos que ISSN: $2174-6419$ Lex Social, vol. 9, núm. 2 (2019) 
menciones mínimas legales) otorgada por las socias fundadoras habrá de inscribirse (como inscripción constitutiva) en el registro administrativo de cooperativas del Ministerio de Trabajo, Migraciones y Seguridad Social ${ }^{92}$ o, en su caso, en el registro competente de la correspondiente Comunidad Autónoma. No está prevista la inscripción adicional en el Registro Mercantil, en tanto las salvedades legales atañen únicamente a las cooperativas de crédito y de seguros ${ }^{93}$; amén de a las sociedades cooperativas europeas con administración central y domicilio social en territorio español ${ }^{94}$. Con un plazo de doce meses se cuenta para la inscripción, y la cuenta empieza a contar desde el otorgamiento de la escritura pública de constitución. Transcurrido ese plazo sin inscripción, el "registro de sociedades cooperativas podrá denegar la inscripción con carácter definitivo" 95 .

Formando parte de la escritura de constitución de la sociedad ${ }^{96}$, los estatutos -regidores del (buen) funcionamiento de la cooperativa- contendrán la siguiente información ${ }^{97}$ : la denominación; el objeto social; el domicilio social; el territorio operativo, como elemento esencial para determinar la legislación a aplicar; el capital social y la aportación obligatoria mínima al capital social ${ }^{98}$; el devengo, en su caso, de intereses por las aportaciones obligatorias; la composición del consejo rector, con la fijación del número de consejeros y del período de duración de su cargo; el número y la duración de la actuación de los interventores y, en el caso de establecerse un comité de recursos, también el número y la duración del cargo de sus miembros integrantes; las reglas para la admisión y la baja, voluntaria u obligatoria, de las socias; el derecho de reembolso y el régimen de transmisión de la aportación; las reglas de disciplina, con la tipificación de las faltas y sanciones, el procedimiento sancionador y las causas de la pérdida de la

se determinen reglamentariamente, o, en su caso, la escritura pública de constitución, en el Registro de Cooperativas Andaluzas". Su artículo 119.1 especifica que "la intervención notarial de la documentación que haya de presentarse al Registro de Cooperativas tendrá carácter potestativo, salvo cuando se aporten bienes inmuebles al capital de la entidad, o en aquellos otros supuestos que puedan establecerse reglamentariamente". Con arreglo a este precepto, el artículo 5.2 del Decreto 123/2014, de 2 de septiembre, por el que se aprueba el Reglamento de la Ley 14/2011, de 23 de diciembre, de Sociedades Cooperativas Andaluzas, dispone que: "la sociedad cooperativa elevará el acta de constitución a escritura pública cuando las aportaciones al capital social consistan en bienes inmuebles, así como cuando se trate de bienes muebles afectados con cargas reales".

${ }^{92}$ De conformidad con el artículo 7 de la Ley estatal de Cooperativas.

${ }^{93}$ Las cooperativas de crédito deben inscribirse, además de en el Registro Mercantil, en el registro correspondiente del Banco de España, conforme al artículo 256.1 del Reglamento del Registro Mercantil; aprobado por el Real Decreto 1784/1996, de 19 de julio (BOE nº 184, 31 julio 1996 [BOE-A-199617533]). Conforme a su apartado segundo: "La ulterior inscripción en el Registro de Cooperativas del Ministerio de Trabajo y Asuntos Sociales, o de la Comunidad Autónoma que corresponda, se hará constar en el Registro Mercantil mediante nota marginal. Esta regla será aplicable asimismo a las cooperativas de seguros".

94 Según dispone el artículo 3.1 de la Ley 3/2011, de 4 de marzo, por la que se regula la Sociedad Cooperativa Europea con domicilio en España (BOE nº 57, 8 marzo 2011, pp. 25803-25809 [BOE-A2011-4288]).

${ }^{95}$ Artículo 10.2, segundo párrafo, de la Ley estatal de Cooperativas.

${ }^{96}$ Artículo 10.1.i) de la Ley estatal de Cooperativas.

${ }^{97}$ En el listado del artículo 11.1 de la Ley estatal.

${ }^{98}$ Además, de la "forma y plazos de desembolso y los criterios para fijar la aportación obligatoria que habrán de efectuar los nuevos socios que se incorporen a la cooperativa”, conforme especifica la letra g) del artículo 11.1 de la Ley estatal. 
condición de socia; además de los derechos y los deberes de las socias y su clasificación.

\section{c. ¿Quiénes son las socias y cuáles son sus derechos y deberes?}

El siguiente interrogante, "quién", enlaza con las clases de socias y con los derechos y deberes que les corresponden. Las socias podrán ser personas físicas -que son las que, a nuestros efectos, interesan- o personas jurídicas, públicas y privadas e, incluso, comunidades de bienes ${ }^{99}$ como entidades sin personalidad jurídica propia. Debe haber socias ordinarias "en activo" o "de pleno derecho", en un número no inferior a tres ${ }^{100}$ según la ley estatal y la mayoría de las leyes autonómicas ${ }^{101}$, , que disminuye (en algún caso, transitoriamente) hasta dos ${ }^{102} \mathrm{o}$ aumenta hasta cinco o diez en algunas Autonomías en función de la clase de cooperativa de que se trate ${ }^{103}$. No habiendo límite numérico máximo en la ley nacional, lo hay en varias leyes autonómicas (las de Castilla La Mancha o La Rioja), hasta diez o veinte socias, con el propósito de establecer topes máximos legales que no conviertan a las cooperativas en sociedades de tamaño macro y las mantengan como "sociedades cooperativas microempresas"104.

Debe haber socias ordinarias o usuarias, realizando la actividad cooperativizada, y puede haber socias colaboradoras (también personas físicas o jurídicas), quienes, no participando en la actividad cooperativizada, sí contribuyen a su consecución y habrán de realizar una aportación económica ${ }^{105}$. Desembolsarán la aportación económica determinada por la asamblea general con un límite máximo del cuarenta y cinco por ciento del total de las aportaciones realizadas al capital social ${ }^{106}$. El tope máximo es sobre las aportaciones totales y sobre los votos totales. El conjunto de los votos de las socias colaboradoras no superará el treinta por ciento de los votos en los órganos sociales ${ }^{107}$.

\footnotetext{
${ }^{99}$ Artículo 12.1 de la Ley estatal.

${ }^{100}$ De conformidad con el artículo 8, y salvo que se establecieran legalmente otros mínimos.

${ }^{101}$ De igual forma, son tres las socias que, al menos, exigen las normativas autonómicas, por ejemplo, de Madrid (primer párrafo del art. 8), Cantabria (art. 5.1), Andalucía (art. 10), Castilla-La Mancha (art. 11), Islas Baleares (art. 11) o La Rioja (art. 5.1).

${ }^{102}$ En la Ley de Cooperativas de Cataluña, el artículo 12.1 faculta a constituir una cooperativa con dos socias, pero en el plazo de cinco años, a contar desde la constitución, habrán de ser tres socias. En la Ley de La Rioja es dos el número mínimo (sin transitoriedad) para las sociedades cooperativas microempresas, de acuerdo al artículo 5.1 in fine.

${ }^{103}$ El artículo 12.1 de la Ley de Cooperativas de Cataluña exige para las cooperativas de consumidores y usuarios un mínimo de diez socias personas físicas. En la Ley Foral de Cooperativas de Navarra la regla general es que sean cinco socias, al menos; salvo para las cooperativas de trabajo asociado, que pueden constituirse con un mínimo de tres socias (art. 20.1).

${ }^{104}$ En la denominación de la Ley de Cooperativas de La Rioja (art. 5.1), para las que hay una limitación máxima de veinte socias. Bajo la denominación de "microempresas cooperativas", la Ley de Castilla-La Mancha exige un mínimo de dos y un máximo de diez socias, en el artículo 11.3.

${ }^{105}$ Artículo 14 de la Ley estatal.

${ }^{106}$ Artículo 14, párrafo tercero, de la Ley estatal de Cooperativas.

${ }^{107}$ Asimismo, según el párrafo tercero del artículo 14.
} ISSN: $2174-6419$ 
A las socias colaboradoras también se las ha denominado y refundido como asociadas o adheridas o inversoras ${ }^{108}$. La nueva normativa extremeña prevé, no obstante, una distinción entre unas y otras, en los artículos 36 y 38. A saber: mientras las colaboradoras contribuyen a la consecución y promoción del fin social mediante la participación en actividades de carácter exclusivamente auxiliar o complementario a la actividad cooperativizada principal, las asociadas efectúan aportaciones al capital social que pueden devengar intereses fijos o variables.

En todo caso puede haber socias de trabajo. Son las socias de trabajo quienes aportan su trabajo personal a la cooperativa. No puede haber esta clase de socias, en cambio, ni en las cooperativas de explotación comunitaria de la tierra ni en las cooperativas de trabajo asociado. Una cooperativa de trabajo asociado será la modalidad de cooperativa que más interesará y convendrá para emprender colectiva y socialmente a las (auto)empleadas domésticas, como habrá luego ocasión de desarrollar y ahora solo de avanzar. Las socias de trabajo - en cualquier otra modalidad de cooperativa distinta a las de trabajo asociado o de explotación comunitaria de la tierra- son personas físicas que prestan su trabajo personal como actividad en la cooperativa de la que son socias ${ }^{109}$. A una socia de trabajo le resulta aplicable el régimen de una socia trabajadora de una cooperativa de trabajo asociado ${ }^{110}$ : no participará en las pérdidas, pero sí en los derechos y en las obligaciones, con criterios equitativos y ponderados.

Una vez sobrevista la clasificación de las socias, quedan por ver, "a vuelo de pájaro", en listado no tasado, los derechos de las socias ${ }^{111}$. Tienen derecho a obtener una formación profesional adecuada. Derecho a participar en la asamblea general y, en concordancia, a ejercitar antes o durante su celebración un amplio derecho de información ${ }^{112}$; salvo que existieran causas de denegación de la información por el consejo rector, quien, sin embargo, no podría denegar una solicitud de información avalada por más de la mitad de los votos ${ }^{113}$. Hay derecho a percibir el retorno cooperativo, de haberse previsto, repartiéndose los excedentes del ejercicio ${ }^{114}$ en función de las actividades y no de las aportaciones $^{115}$. Hay derecho, no a percibir dividendos, a percibir intereses, no en todo caso, solo en su caso. Si se trata de aportaciones obligatorias en el caso de que se haya pactado estatutariamente. Si se trata de aportaciones voluntarias, cuando y como el acuerdo de admisión establezca esta remuneración o el procedimiento para la

${ }^{108}$ Vid. MORILLAS JARILLO, M. ${ }^{a}$ J.: Las sociedades cooperativas..., op. cit., p. 50; MORILLAS JARILLO, M. ${ }^{\text {a. }}$ FELIÚ REY, M.: Curso..., op. cit., p. 204.

${ }^{109}$ Artículo 13.4.

${ }^{110}$ También artículo 13.4 .

${ }^{111}$ Artículo 16.

${ }^{112}$ En los extensos términos del artículo 16.3.

${ }^{113}$ Artículo 16.4.

${ }^{114} \mathrm{El}$ restante tras integrar los fondos sociales obligatorios, esto es, el fondo de reserva obligatorio y el fondo de educación y promoción. Artículos 55 y 56 de la Ley estatal.

${ }^{115}$ Con la excepción del artículo 107.4 de la Ley de Cooperativas estatal cuando para las cooperativas mixtas dispone que: "Los excedentes imputables a los poseedores de partes sociales con voto se distribuirán entre ellos en proporción al capital desembolsado". 
determinación ${ }^{116}$, se recuerda. La remuneración de la aportación no excederá en más de seis puntos del interés legal del dinero ${ }^{117}$. Hay, además, derecho de participación en las actividades cooperativizadas "sin discriminación"118.

La participación es un derecho y un deber. Hay obligación de participar en las actividades cooperativizadas en la cuantía mínima obligatoria establecida en los estatutos $^{119}$. Asimismo, hay obligación de guardar secreto respecto de aquellos asuntos cuya difusión pudiera ocasionar perjuicios al interés social ${ }^{120}$. La obligación de mantener secreto se complementa con la de no competir por cuenta propia con la cooperativa, salvo que se reciba una autorización del consejo rector ${ }^{121}$. A las anteriores obligaciones se suma la de aceptación de los cargos para los que fueran las socias elegidas, salvo justa causa ${ }^{122}$. También, la obligación de cumplir con las obligaciones económicas que correspondan ${ }^{123}$. Finalmente, el abandono puede ser visto desde una doble perspectiva: el deber o el derecho. Hay un derecho de abandono voluntario, sin más limitación que la de respetar el plazo que hubiera sido establecido en los estatutos, nunca superior al año ${ }^{124}$, o que la de cumplir con la exigencia estatutaria del compromiso de la socia de no ejercitar su derecho de baja sin justa causa con anterioridad al transcurso del ejercicio económico o de un plazo no superior a cinco años desde su admisión ${ }^{125}$. El abandono puede ser, no obstante, un deber. Habría baja obligatoria $^{126}$, con acuerdo previo del consejo rector, si dejaran de cumplirse los requisitos legales o estatutarios para el mantenimiento de la condición de socia. También podría haber expulsión ${ }^{127}$, aunque esté reservada para los supuestos de las faltas más graves.

\section{d. ¿Cuánto es el coste y cuál es la responsabilidad?}

Esbozados los derechos y los deberes de las socias, y antes descrita la clasificación de las socias, conviene prestar atención, a continuación, a su responsabilidad. La regla aplicable es la responsabilidad limitada a lo aportado. En efecto, el artículo 15.3 de la Ley estatal manifiesta que la responsabilidad de la socia por las deudas sociales queda limitada a las aportaciones efectuadas al capital social. Esta regla de no responsabilidad por las deudas sociales entiende la doctrina ${ }^{128}$ que no se altera por el hecho de que, si la socia causa baja en la cooperativa, se le haga responder durante los siguientes cinco

\footnotetext{
116 Artículo 48.1.

117 Apartados primero y segundo del artículo 48. El tipo de interés en 2019 es el 3\%.

${ }^{118}$ En expresión empleada por el artículo 16.2.c).

${ }^{119}$ Artículo 15.2.b).

${ }^{120}$ Artículo 15.2.c).

${ }^{121}$ Artículo 15.2.f).

122 Artículo 15.2.d).

123 Artículo 15.2.e).

${ }^{124}$ Artículo 17.1.

125 Artículo 17.3.

${ }^{126}$ Artículo 17.5.

${ }^{127}$ Artículo 18.5.

${ }^{128}$ Vid. BROSETA PONT, M.; MARTÍNEZ SANZ, F.: Manual..., op. cit., p. 667.
} ISSN: $2174-6419$ 
años de las obligaciones que hubiera contraído la cooperativa antes de su baja, "hasta el importe reembolsado de sus aportaciones al capital social", según la literalidad del apartado siguiente del precepto ahora en estudio.

Su responsabilidad queda limitada a su aportación al capital social. Si esta es la regla de la Ley estatal, hay que puntualizar que la normativa valenciana, aunque señala que la responsabilidad es "limitada al importe nominal de las aportaciones al capital social, permite que los estatutos dispongan la responsabilidad ilimitada de los socios por las deudas sociales, en cuyo caso regiría la mancomunidad simple, salvo que los estatutos recogieran la solidaridad ${ }^{129}$. También las legislaciones madrileña y aragonesa posibilitan que los estatutos prevean la responsabilidad ilimitada de las socias por las deudas sociales ${ }^{130}$. Asimismo, la navarra ofrece la alternativa de que los estatutos dispongan la responsabilidad limitada o ilimitada de las socias por las deudas sociales contraídas frente a los terceros. Pero, interesando que las socias-trabajadoras del hogar no respondieran por las deudas que frente a los terceros contrajera la cooperativa, interesaría no recoger en los estatutos sociales de una cooperativa regida, por ejemplo, por la legislación de Valencia, Madrid, Aragón o Navarra su responsabilidad ilimitada. No disponiendo en los estatutos que respondieran ilimitadamente con todo su patrimonio presente o futuro, tendrían la responsabilidad limitada al importe nominal de sus aportaciones al capital.

El capital social está integrado por las aportaciones de las socias y las aportaciones se dividen en obligatorias y voluntarias ${ }^{131}$. La aportación obligatoria ${ }^{132}$ mínima para convertirse en socia vendrá establecida en los estatutos sociales. Esa aportación obligatoria mínima inicial podrá divergir para las distintas clases de socias o para cada socia en concreto, en proporción al compromiso o al uso potencial que cada una de ellas asuma en la actividad cooperativizada, según prescribe (en masculino que feminizamos) el artículo 46.1 de la Ley estatal de Cooperativas. Las obligatorias, iguales o diferentes, habrán de estar desembolsadas en un veinticinco por ciento en el momento de su suscripción y el monto restante en el plazo que señalen bien los estatutos o bien la asamblea general ${ }^{133}$. Las voluntarias, de ser acordada su admisión por la asamblea o, si lo previeran los estatutos, por el consejo rector ${ }^{134}$, deberán ser desembolsadas íntegramente al momento de su suscripción. Ya sean obligatorias o voluntarias, pueden ser reembolsables, en caso de baja, o pueden no serlo, en reembolso rehusado incondicionalmente por el consejo rector ${ }^{135}$. Unas $\mathrm{u}$ otras pueden ser dinerarias (en

\footnotetext{
${ }^{129}$ Artículo 4.2 del Decreto Legislativo 2/2015.

${ }^{130}$ Artículo 5.3 de la Ley 4/1999 de la Comunidad de Madrid y artículo 47.1 del Texto Refundido de la Ley de Cooperativas de Aragón.

${ }^{131}$ Artículo 45.1 de la Ley estatal.

132 Artículo 46.

133 Artículo 46.3.

134 Artículo 47.

${ }^{135}$ Letras a) y b) del artículo 45.1.
} 
moneda de curso legal) ${ }^{136}$ o no dinerarias, en bienes o derechos susceptibles de valoración económica $^{137}, \mathrm{y}$, en este caso, bajo informe pericial ${ }^{138}$.

Integrado por aportaciones en dinero o in natura, el importe del capital social mínimo vendrá determinado en los estatutos. La libre determinación del importe del capital inicial mínimo (con total desembolso desde su constitución) ${ }^{139}$ encuentra límites no en la ley estatal sino en las leyes autonómicas, pero no en todas las autonómicas, en tanto tampoco exigen un mínimo legal las leyes de las Comunidades andaluza ni murciana. La cuantía del capital social mínimo legal varía en función de las restantes autonomías. Las variaciones afectan al importe mínimo y al porcentaje del desembolso. Mientras que la ley estatal exige el total desembolso, hay legislaciones autonómicas que reducen el desembolso a un veinticinco por ciento en el momento de la suscripción, según ejemplificamos, a continuación: mil quinientos euros desembolsado en un veinticinco por ciento ${ }^{140}$; mil ochocientos (o mil ochocientos tres ${ }^{141}$ [sic]) euros totalmente desembolsado $^{142}$ o solo desembolsado en un veinticinco por ciento ${ }^{143}$; o tres mil euros con completo desembolso ${ }^{144}$ o con parcial desembolso de una cuarta parte ${ }^{145}$.

Con estas menciones iniciales al capital social -ejemplificativas y dispares en función de la norma autonómica que regula cada cooperativa-, estaríamos tratando de responder a la pregunta acerca de "cuánto" cuesta constituirla. Junto con las anteriores referencias hay que recalcar la alusión a la variabilidad del capital social. La variabilidad está en función de la entrada y de la salida de las socias, sin necesidad de modificar los

\footnotetext{
136 Artículo 45.4.

137 También apartado cuarto del artículo 45.

138 Artículo 45.1.

139 Artículo 45.2.

${ }^{140}$ El primer párrafo del artículo 7 de la Ley Foral de Cooperativas de Navarra expresa que "el capital social [...] no será inferior a 1.500 euros" y el tercer párrafo especifica que "en el momento de la constitución, el capital deberá hallarse suscrito íntegramente y desembolsado al menos en un 25 por 100 de su importe por los socios promotores de la cooperativa".

${ }^{141}$ Mil ochocientos tres euros, totalmente suscrito y desembolsado, concreta el artículo 69.2 de la Ley de Cooperativas de las Islas Baleares. En el mismo sentido, se expresa el artículo 61.2 de la Ley de Cooperativas de La Rioja.

${ }^{142}$ El total desembolso de los mil ochocientos tres euros lo exigen tanto la legislación balear como la riojana.

${ }^{143}$ En cambio, la normativa madrileña permite en el momento constitutivo el desembolso en un $25 \%$ de los mil ochocientos euros que exige el artículo 49, con la excepción legal de las cooperativas escolares para las que hay admisión de "cualquier cuantía".

${ }^{144}$ En la Ley de Cooperativas de la Comunidad de Castilla y León el artículo 4 (“capital social mínimo") exige tres mil euros, en la nueva redacción otorgada a este artículo por la Ley 2/2018, de 18 de junio (BOCL 25 junio 2018); incrementando la cuantía en mil euros. Bajo idéntica rubrica, el artículo 5 de la Ley de Cooperativas de Galicia exige, en su apartado primero (y en la redacción de la Ley 6/2016, de 4 de mayo, de la Economía Social de Galicia [DOG 18 mayo 2016]), un capital mínimo legal de tres mil euros, completamente desembolsado desde la constitución. Por su parte, la nueva Ley extremeña fija en su artículo 5.3 un capital no inferior a tres mil euros íntegramente desembolsado; especificando en el apartado siguiente que si el capital fuese superior "deberá estar desembolsado desde la constitución de la sociedad cooperativa, la mayor de las cantidades siguientes: tres mil euros, o el $25 \%$ del capital social mínimo previsto en los estatutos". Por tres mil euros totalmente desembolsados desde el inicio también optan las legislaciones de Castilla La Mancha (art. 7.1), País Vasco (art. 4), Comunidad Valenciana (art. 55.2), Cataluña (art. 70.2) o Asturias (art. 4.1).

${ }^{145}$ Como indican las legislaciones cántabra y aragonesa (arts. 6 y 48.1, respectivamente). ISSN: 2174-6419 Lex Social, vol. 9, núm. 2 (2019)
} 
estatutos, por encima de la cifra del capital social mínimo estatutario ${ }^{146}$. Como el capital social se integra por las aportaciones obligatorias o voluntarias de las socias, la cifra del capital va incrementándose si ingresan en la cooperativa nuevas socias o, en caso contrario, va reduciéndose cuando se separan de ella. En efecto, la variabilidad del capital social viene enlazada con la variabilidad del número de socias, en tanto es libre su entrada y salida, en virtud del remarcado principio de puerta abierta.

Para finalizar este extremo, dato que destacar es que el capital social no cumple en las sociedades cooperativas las mismas funciones que en las sociedades mercantiles capitalistas. Conforme ha incidido la doctrina ${ }^{147}$, las aportaciones de las socias no representan una parte alícuota de todo el patrimonio, sino del patrimonio neto repartible. El irrepartible, de carácter colectivo, viene adscrito a fines de consolidación y garantía y a formación y educación, y se integra, respectivamente, por los fondos de reserva obligatoria $^{148}$ y de educación y promoción ${ }^{149}$. Mientras el primero se destina - se transcribe- "a la consolidación, desarrollo y garantía de la cooperativa", en virtud del punto primero del artículo 55 de la ley estatal; el segundo -inembargable e irrepartible ${ }^{150}$ - se dirige a la formación y la educación de las socias y trabajadoras en los principios cooperativos, en especial, en las materias que tienen relación con la actividad cooperativizada o, en general, en las de promoción y difusión profesional o asistencial, en el listado más amplio de fines que contiene el artículo 56.1 de la citada ley.

\section{e. ¿Cómo organizar?}

Una vez que han sido descritas tanto la constitución como la capitalización, queda por conocer el "cómo" debe o puede ser la organización. Pueden ser necesarios o voluntarios los órganos sociales ${ }^{151}$. En los voluntarios -como el comité de recursos ${ }^{152}$, para la resolución de los posibles conflictos internos; o como las comisiones, comités o consejos con carácter asesor o consultivo- no podemos ahora siquiera detenernos. La parada -siquiera corta- ha de hacerse en los órganos necesarios ${ }^{153}$, esto es, en la asamblea general, como órgano de deliberación y decisión; en el órgano de administración (cuando es colegiado, el consejo rector), como órgano de gestión interna y de representación externa; y en la intervención, por ser el órgano de supervisión. El matiz que incluir, antes de proseguir, enlaza con la adjetivación como "necesario" del

\footnotetext{
${ }^{146}$ Artículos 45.2 y 8 de la Ley estatal.

${ }^{147}$ Así, BROSETA PONT, M.; MARTÍNEZ SANZ, F.: Manual..., op. cit., p. 668; citando a VICENT CHULIÁ.

148 Artículo 55.

149 Artículo 56. Respecto de la educación y formación cooperativa, en general, y los fondos sociales obligatorios para la educación y la promoción, en particular, tanto en la legislación estatal como en la autonómica (vasca), léanse, por ejemplo, los comentarios recientemente vertidos en: MARTÍNEZ ETXEBERRÍA, G.: La aplicación efectiva de los valores..., op. cit., pp. 47-62

${ }^{150}$ Artículo 56.5.

${ }^{151}$ Vid. VICENT CHULIÁ, F.: "Los órganos sociales de la cooperativa". Revista Jurídica de Cataluña, vol. $77, \mathrm{n}^{\circ} 1,1978$, pp. 65-118.

152 Artículo 44.1 de la Ley 27/1999

153 Artículo 19. 
órgano de supervisión. Su carácter necesario se precisa en la ley estatal ${ }^{154}$, así como en la mayoría de las normativas autonómicas; pero no así en algunas regionales, como la cántabra $^{155}$, la catalana ${ }^{156}$ o la andaluza ${ }^{157}$, donde es potestativo este órgano de fiscalización de las cuentas.

La reunión de las socias, a fin de reflexionar y de debatir para llegar a acuerdos, se hará en la asamblea general ${ }^{158}$ (ordinaria ${ }^{159}$, extraordinaria ${ }^{160}$ y universal ${ }^{161}$ ). Es el foro de expresión de la voluntad social de la sociedad cooperativa, al modo en que lo es la junta general de una sociedad mercantil de capital ${ }^{162}$, como órgano supremo (con supremacía venida a menos en una gran sociedad anónima, más aún si es cotizada). La asamblea general de la sociedad cooperativa establece la política general, pudiendo impartir instrucciones al consejo rector o someter a autorización determinados asuntos de este órgano colegiado de administración, salvo disposición estatutaria contraria ${ }^{163}$; a semejanza de la posibilidad existente para cualquier sociedad mercantil de capital (antes de 2014 solo para la sociedad de responsabilidad limitada) de impartición de instrucciones de la junta general al órgano de administración o el sometimiento a su autorización de la adopción de decisiones o acuerdos sobre ciertos asuntos de gestión, también salvo disposición contraria estatutaria ${ }^{164}$. Aparte de fijar la política general de la cooperativa, la asamblea general examina la gestión social (con aprobación de las cuentas anuales y de los informes de gestión y de aplicación de los excedentes disponibles, en caso de ganancias, o, en su caso, de imputación de pérdidas) ${ }^{165}$. También puede modificar, en su caso, los estatutos o, de haberlo, el reglamento del régimen interno de la cooperativa ${ }^{166}$; o, entre otras competencias (listadas en el artículo

\footnotetext{
154 Ídem.

${ }^{155}$ En virtud del artículo 55 de la Ley 6/2013 de Cooperativas de Cantabria.

${ }^{156}$ Artículo 65.1 Ley de Cooperativas de Cataluña.

${ }^{157}$ Para las sociedades cooperativas con más de diez personas, lo podrán prever los estatutos, de acuerdo con el artículo 44.1 de la Ley de Sociedades Cooperativas Andaluzas.

${ }^{158}$ Artículo 20 de la Ley estatal. Vid. VICENT CHULIÁ, F.: "La asamblea general de la cooperativa". Revista Jurídica de Cataluña, vol. 77, n 2, 1978, pp. 417-498.

${ }^{159} \mathrm{La}$ asamblea general ordinaria será convocada en los seis meses siguientes a la fecha de cierre del ejercicio económico. Su propósito es examinar la gestión social y aprobar, en su caso, las cuentas anuales, conforme disponen los artículos 22.1 y 23.1 de la Ley estatal.

${ }^{160}$ El tercer párrafo del artículo 22.1 de la Ley estatal abre el cajón de sastre de las asambleas generales extraordinarias, al definirlas como cualquiera asamblea que no tenga el carácter de ordinaria.

${ }^{161}$ A la asamblea general universal alude el artículo 43 de la Ley de Cooperativas de Extremadura, definiéndola como aquélla en la que puede tratarse cualquier asunto, cuando estén presentes o representados todas las socias si se acepta la reunión unánimemente.

${ }^{162} \mathrm{La}$ similitud de estructura y funcionamiento entre la asamblea general de la sociedad cooperativa y la junta general de la sociedad anónima la pusieron de manifiesto, por ejemplo: BROSETA PONT, M.; MARTÍNEZ SANZ, F.: Manual..., op. cit., p. 669.

163 Artículo 21.1, párrafo segundo, de la Ley estatal.

${ }^{164}$ De conformidad con el artículo 161 del Texto Refundido de la Ley de Sociedades de Capital, aprobado por el Real Decreto Legislativo 1/2010, de 2 de julio (BOE $n^{\circ}$ 161, 3 julio 2010 [BOE-A-2010-10544]); en la redacción que a este artículo 161 otorgó el artículo único.2 de la Ley 31/2014, de 3 de diciembre (BOE $\mathrm{n}^{\circ}$ 293, 4 diciembre 2014 [BOE-A-2014-12589]), para extender esta posibilidad de impartición de instrucciones desde las sociedades de responsabilidad limitada al resto de las sociedades de capital.

165 Artículo 21.2.a) de la Ley de Cooperativas estatal.

${ }^{166}$ Apartado c) del artículo 21.2.
} 
21.2 de la ley estatal), nombrar y revocar a los miembros del consejo rector y a los interventores.

Como administradoras pueden ser elegibles y elegidas quienes sean socias, en virtud del rasgo del auto-organicismo que impregna la gestión cooperativa. Esta es una regla general que cuenta con una salvedad: las administradoras pueden no ser socias ${ }^{167}$. La salvedad legal cuenta, a su vez, con restricciones cuantitativas: hasta un tercio del total de miembros del consejo rector pueden no ser socias, de conformidad con el artículo 34.2 de la regulación estatal y, a su compás, con los respectivos preceptos de las regulaciones autonómicas navarra, murciana, riojana, balear, andaluza o cántabra o extremeña ${ }^{168}$. El compás se pierde en otras normativas regionales, en tanto la aragonesa, la castellanomanchega, la madrileña, la gallega y la vasca permiten la entrada en el consejo rector de personas expertas y cualificadas no socias en número no superior a la cuarta parte del total ${ }^{169}$, y la castellanoleonesa con un máximo del veinte por ciento ${ }^{170}$. Sin condiciones numéricas admite, en cambio, la participación de personas no socias con experiencia y cualificación profesional la normativa asturiana ${ }^{171}$.

Sean socias o no, con o sin límites, las administradoras son las gestoras internas y las representantes externas. Aunque hablemos en plural de administradoras, puede haber una única administradora. La ley estatal lo señala desde la Exposición de Motivos para las cooperativas con menos de diez socias. Además de la legislación estatal, las vasca, navarra, andaluza y riojana también lo posibilitan para cooperativas con hasta diez socias ${ }^{172}$, mientras que la murciana permite vía estatutos esta forma de administración única en cooperativas con un número inferior a cinco socios ${ }^{173}$. Una o dos administradoras, en este último caso, con actuación mancomunada o solidaria, son fórmulas de administración viable en las cooperativas de Castilla La Mancha ${ }^{174}$; pudiendo los estatutos establecer distintos modos de organización de la administración (incluyendo también al consejo rector) y atribuyendo a la asamblea general la opción de elección sin modificación estatutaria ${ }^{175}$; al estilo en cómo se permite esta opción en las

\footnotetext{
${ }^{167}$ Artículo 34.2 de la Ley estatal. En la misma dirección se pronuncia el artículo 57.1 de la Ley de Cooperativa de Castilla La Mancha. Su artículo 57.4.b) matiza: "si no se prohibiere" esta posibilidad de elección de cualquier tercero no socia.

168 Artículo 37.3 de la Ley Foral de Cooperativas de Navarra, artículo 50.2 de la Ley de Cooperativas de Murcia, artículo 48.1 de la Ley de Cooperativas de La Rioja, artículo 50.3 de la Ley de Cooperativas de las Islas Baleares, artículo 36 de la Ley de Sociedades Cooperativas Andaluzas, artículo 45.3 de la Ley de Cooperativas de Cantabria y artículo 50.5 de la Ley de Cooperativas de Extremadura.

${ }^{169}$ Artículo 38.2 de la Ley de Cooperativas de Aragón, artículo 66.3 de la Ley de Cooperativas de Castilla-La Mancha, artículo 41 de la Ley de Cooperativas de la Comunidad de Madrid, artículo 44.1 de la Ley de Cooperativas de Galicia y, finalmente, el artículo 41.2 de la Ley de Cooperativas del País Vasco ${ }^{170}$ Así, el artículo 42.3 de la Ley de Cooperativas de Castilla y León.

${ }^{171}$ Artículo 61.1de la Ley de Cooperativas de Asturias.

172 Artículo 32 de la Ley de Cooperativas estatal. Asimismo, artículo 41.1 de la Ley de Cooperativas del País Vasco, artículo 37.2 de la Ley Foral de Cooperativas de Navarra, art. 36 de la Ley de Sociedades Cooperativas Andaluza y artículo 47.1de la Ley de Cooperativas de La Rioja.

${ }^{173}$ Párrafo segundo del artículo 48.1de la Ley de Cooperativas de la Región de Murcia.

${ }^{174}$ Artículo 55.1 de la Ley de Cooperativas de Castilla La Mancha.

175 Artículo 55.2 de la Ley de Cooperativas de Castilla La Mancha.
} ISSN: 2174-6419

Lex Social, vol. 9, núm. 2 (2019) 
sociedades de responsabilidad limitada ${ }^{176}$. Es posible también una o dos administradoras, que actúen conjunta o solidariamente, en las cooperativas de hasta diez socios en las Comunidades de Cantabria, Aragón o Cataluña ${ }^{177}$. Como órgano colegiado de gobierno, estaría el consejo rector, integrado por un mínimo de dos ${ }^{178}$ o tres ${ }^{179}$ personas. Le compete la alta gestión, la supervisión de directivos y las facultades representativas extendidas a los actos que mantienen relación con las actividades que integran el objeto social ${ }^{180}$.

Amén de la asamblea general y el órgano de administración, el tercer órgano necesario es la intervención para la fiscalización. La necesidad que promulga la ley estatal -se recuerda- se convierte en voluntariedad en las leyes cántabra, catalana y andaluza ${ }^{181}$. Necesaria en las demás, se evidencia, una vez más, no solo la variedad sino la disparidad regulatoria. En cualquier caso, su cometido es la fiscalidad para la censura de las cuentas anuales y del informe de gestión, antes de su sometimiento a la aprobación en la asamblea general; salvo que la cooperativa, de gran tamaño, estuviera sujeta a auditoría de cuentas. Fiscalización no solo para la contabilidad sino además para la consulta y comprobación de la documentación y para proceder a su verificación ${ }^{182}$. Fiscalización amplia por un órgano de intervención compuesto por titulares en un número no superior al número de consejeras; más suplentes, en el caso y en el número que fueran establecidos por los estatutos ${ }^{183}$. Las interventoras son socias ${ }^{184}$; aun con la posibilidad, en un tercio, de incluir a expertas independientes ${ }^{185}$.

\subsection{Cooperativa de trabajo asociado para la emprendedora del hogar.}

Habiendo sido esbozados a trazos gruesos los rasgos generales de las cooperativas, planteados a modo de sumarias respuestas a simples interrogantes, es tarea por abordar

\footnotetext{
${ }^{176}$ Lo permite el artículo 210.3 del Texto Refundido de la Ley de Sociedades de Capital.

${ }^{177}$ Artículo 41.2 de la Ley de Cooperativas de Cantabria, artículo 38.9 de la Ley de Cooperativas de Aragón y artículo 43.2 de la Ley de Cooperativas de Cataluña.

${ }^{178}$ Por un número de dos personas se integra en las cooperativas compuestas por tres socios, según las Leyes de Cooperativas de La Rioja (art. 47.1), Castilla y León (art. 41.1) e Islas Baleares (art. 49.1). También, en cooperativas especiales como la de trabajo asociado, cuando está compuesta por un número menor a cuatro socias, de conformidad con el artículo 43.1de la Ley de Cooperativas de Galicia. Asimismo, en las cooperativas de dos socias, en las que el consejo rector estará integrado por estos dos miembros, según la Ley de Cataluña (art. 55.2.b)). Por último, la Ley 6/2008, de 25 de junio, de la Sociedad Cooperativa pequeña de Euskadi indica en su artículo 5.5que: "el órgano de administración y representación de las sociedades cooperativas pequeñas, cuando se opte por la modalidad de consejo rector, estará integrado como mínimo por dos personas".

${ }^{179}$ Un mínimo de tres personas indica no solo la Ley de Cooperativas estatal (art. 33) sino también las autonómicas de Castilla La Mancha (art. 41), Extremadura (art. 50.1) y Cataluña (art. 55.2.b, como regla general, salvo que la cooperativa se integrase solo por dos socias, en cuyo caso el consejo rector también estaría integrado por dos).

${ }^{180}$ Artículo 32.1de la Ley estatal.

${ }^{181}$ Para las referencias legales, consúltense supra las notas a pie de página no 155,156 y 157.

182 Artículo 38.1 de la Ley estatal.

${ }^{183}$ Artículo 38.2.

${ }^{184}$ Apartados $2^{\circ}$ y $3^{\circ}$ del artículo 38 de la Ley estatal.

${ }^{185}$ Artículo 38.3, párrafo segundo.
} 
deslindar, entre los tipos de cooperativas ${ }^{186}$, aquellas clases que, por su definición y caracteres particulares, pueden mejor acoplarse al servicio doméstico. De la tipología legal ${ }^{187}$, conviene destacar las cooperativas de trabajo ${ }^{188}$ asociado $^{189}$. Se regulan, como primera clase, en el capítulo décimo, sección primera, artículos 80 a 87, de la ley estatal.

El primer apartado del primero de los preceptos mencionados define literalmente a las de trabajo asociado como las cooperativas que "proporcionan a sus soci[a]s puestos de trabajo, mediante su esfuerzo personal y directo, a tiempo parcial o completo, a través de la organización en común de la producción de bienes o servicios para terceros". Las socias trabajadoras llevan a cabo una prestación laboral y por medio de su trabajo desarrollan la actividad cooperativizada. La relación de las socias trabajadoras con la cooperativa es, no obstante, societaria; conforme se encarga de expresar in fine ese primer apartado. Avanza el apartado segundo del artículo en estudio exponiendo $a b$ initio que pueden ser socias trabajadoras (españolas o extranjeras) "quienes legalmente tengan capacidad para contratar la prestación de su trabajo". Junto con las socias trabajadoras pudiera haber socias colaboradoras.

El procedimiento de acceso de la trabajadora a la condición de socia de una cooperativa de trabajo asociado podrá ser establecido en los estatutos. Si en ellos se contemplara la admisión (a cargo del consejo rector) de la nueva socia en situación de prueba lo sería por un período no superior a seis meses, con posibilidad de reducción o, incluso, de supresión de dicho período por acuerdo mutuo ${ }^{190}$.

Cuando la trabajadora se convierta en socia tendrá derecho al descanso semanal, a las fiestas, las vacaciones y los permisos en los términos regulados por los estatutos, por el reglamento de régimen interior o, de no haber en ellos regulación en este extremo, por la asamblea general, con respeto a las normas mínimas legales del artículo 83 de la ley estatal de cooperativas. Estas reglas suponen la formalización de días para el descanso semanal y los períodos para las vacaciones y los permisos en un sector como el del cuidado del hogar que fuera del mundo cooperativo se mueve en gran parte en la economía informal. Cuando la relación es directa entre la empleada y la empleadora del hogar, por no haber de por medio una empresa (en este caso, con forma de cooperativa),

\footnotetext{
${ }^{186}$ En específico, sobre las clases de cooperativas, léase, por ejemplo: PORTELLANO DÍEZ, P.: "El sistema de clases en la Ley de Cooperativas: un alegato a favor de la simplicidad legal". Revista de Derecho de Sociedades, $\mathrm{n}^{\circ}$ 19, 2002, pp. 57-72.

${ }^{187}$ La tipología legal de cooperativas se recoge en la Ley estatal en el Título I, Capítulo X (dividido en doce secciones: arts. 80 a 104) y Capítulo XI (dividido en tres secciones más: arts. 105 a 107).

${ }^{188}$ En general, léase, por todos, GÓMEZ-CALCERRADA GASCÓN, J. L.: La cooperativa de trabajo. Barcelona: CEAC, 1983.

${ }^{189}$ Véase un temprano estudio, antes de la vigente Ley estatal de cooperativas, en: LLOBREGAT HURTADO, M. ${ }^{a}$ L.: "Reflexiones sobre el régimen jurídico de las sociedades anónimas laborales y las cooperativas de trabajo asociado". CIRIEC - España. Revista Jurídica de Economía Social y Cooperativa, $\mathrm{n}^{\circ} 8,1996$, pp. 123-142. Un ejemplo añadido de cooperativa de trabajo asociado en el sector doméstico es la Cooperativa de Trabajo Asociado de Trabajadoras del Servicio Doméstico, domiciliada en Santander.

${ }^{190}$ Conforme al artículo 81 , en sus apartados primero y segundo. 
abundantes veces en la práctica no hay límites prefijados para la jornada laboral ni días establecidos para los descansos ni los permisos ${ }^{191}$. Así es en ocasiones en la realidad, pese a que en la teoría el Real Decreto 1620/2011, de 14 de noviembre, por el que se regula la relación laboral de carácter especial del servicio del hogar familiar, incorpore la fijación del horario de trabajo de común acuerdo entre trabajadora y empleadora, el incremento del descanso entre jornadas, el disfrute de un descanso semanal consecutivo de treinta seis horas, o la determinación de los períodos de disfrute de las vacaciones ${ }^{192}$.

También tendrá derecho la socia de la cooperativa de trabajo asociado a una remuneración sin la consideración de salario y con la denominación de "anticipo societario". La remuneración se concreta, en los términos del apartado cuarto del artículo 80, en percepciones periódicas ("en plazo no superior a un mes") a cuenta de los excedentes de la cooperativa, en función de la participación de cada socia en la actividad cooperativizada. La suspensión temporal de la obligación y del derecho de la socia trabajadora a prestar su trabajo, con la correlativa pérdida de los derechos y las obligaciones económicas (conservando en algunos casos los derechos y las obligaciones no económicas) ${ }^{193}$ que van ligadas a esa prestación de trabajo, será por las causas que refleja el artículo 84, entre las que se incluyen las siguientes: la incapacidad temporal ${ }^{194}$; la maternidad ${ }^{195}$, la adopción o el acogimiento de menores de cinco años ${ }^{196}$; la excedencia forzosa, por designación o elección a un cargo público o a un cargo propio del movimiento cooperativista que sea incompatible o imposibilite la prestación del trabajo por parte de la socia trabajadora; las causas económicas, técnicas, organizativas, productivas o de fuerza mayor ${ }^{197}$; o las razones disciplinarias. Al cesar las causas de suspensión, resurgen los derechos y las obligaciones económicas y el derecho a la reincorporación en el mismo puesto de trabajo ${ }^{198}$. Ni con suspensión ni sin ella hay

\footnotetext{
${ }^{191}$ Recalcamos que SANDE PÉREZ-BEDMAR, M. DE, “La relación laboral especial...”, op. cit., p. 154, indicó que: "el 57\% de los trabajadores no tienen marcado un límite sobre jornada laboral semanal; cerca del $45 \%$ tampoco tiene un día fijo o señalado para el descanso semanal, ni permisos por maternidad, y la gran mayoría trabaja en el sector informal de la economía”.

${ }^{192}$ Las novedades en este sentido se explicitan y resumen en la Exposición de Motivos.

${ }^{193}$ El artículo 84.4 de la Ley estatal dispone literalmente que: "Los socios trabajadores incursos en los supuestos a), b), d) y f) del número 1 de este artículo, mientras estén en situación de suspensión, conservarán el resto de sus derechos y obligaciones como socio".

194 "En el supuesto de incapacidad temporal si, de acuerdo con las leyes vigentes sobre Seguridad Social, el socio trabajador es declarado en situación de incapacidad permanente, cesará el derecho de reserva del puesto de trabajo, y si fuese absoluta o gran invalidez, se producirá la baja obligatoria del socio trabajador".

195 Son dieciséis las semanas, como mínimo y, en el supuesto de un parto múltiple, dieciocho.

196 "En el supuesto de adopción, si el hijo adoptado es menor de nueve meses, la suspensión tendrá una duración máxima de dieciséis semanas contadas, a la elección del socio trabajador, bien a partir de la decisión administrativa o judicial de acogimiento, bien a partir de la resolución judicial por la que se constituye la adopción. Si el hijo adoptado es mayor de nueve meses y menor de cinco años, la suspensión tendrá una duración máxima de seis semanas".

${ }^{197}$ El texto literal del artículo 84.3 manifiesta que: "la asamblea general, salvo previsión estatutaria, deberá declarar la necesidad de que, por alguna de las mencionadas causas, pasen a la situación de suspensión la totalidad o parte de los socios trabajadores que integran la cooperativa, así como el tiempo que ha de durar la suspensión y designar los socios trabajadores concretos que han de quedar en situación de suspensión".

198 Artículo 84.2. 
derecho a sindicación ${ }^{199}$; en tanto la relación de la socia trabajadora no es laboral sino societaria, se recuerda.

De conformidad con el artículo 8 del Real Decreto 84/1996, del reglamento general sobre inscripción de empresas y afiliación, altas, bajas y variaciones de datos de los trabajadores ["las trabajadoras", desde nuestra mirada feminizada] en la Seguridad Social $^{200}$, las socias trabajadoras de las cooperativas de trabajo asociado (como óptima clase cooperativa para el trabajo del hogar, repetimos) serán dadas de alta bien como asimiladas a las trabajadoras por cuenta ajena en el régimen general o bien como autónomas en el régimen especial, previa opción de la cooperativa y con reflejo en sus estatutos $^{201}$. Si la opción de la cooperativa fuese el régimen especial de trabajadoras autónomas, la cotización sería por cuenta de la socia, respondiendo solidariamente la cooperativa de que las socias cumpliesen con su obligación de cotizar ${ }^{202}$. Si, por el contrario, la cooperativa se decantara por el régimen general sería su obligación la de la afiliación, alta y baja; además de la cotización a cargo de la propia cooperativa por la parte que le correspondiera como empresaria.

Tras la opción de la cooperativa, con el correspondiente reflejo estatutario, bien por el régimen de afiliación general o bien por el de autónomas, a las socias trabajadoras les serán aplicables en su integridad las normas reguladoras que correspondan al régimen elegido, "en iguales términos y condiciones que los aplicables al común de los colectivos que formen parte del campo de aplicación de dicho régimen", en la literalidad del apartado cuarto del citado artículo 8. En atención a este precepto, las socias trabajadoras gozarían de protección por la contingencia de desempleo ante su baja de la cooperativa. De haber optado la cooperativa por el régimen general, las socias trabajadoras tendrían protección por desempleo por las siguientes causas ${ }^{203}$ : el cese durante el período de prueba si se hubiera fijado tal período; la expulsión improcedente; el cese temporal o definitivo por causas tecnológicas, económicas o de fuerza mayor; la reducción temporal de la jornada de trabajo por las anteriores causas en, al menos, una tercera parte; o el fin temporal de una relación societaria de duración determinada. De optar, en cambio, por el régimen de autónomas, tendrían las socias trabajadoras un

\footnotetext{
${ }^{199}$ La sentencia de la Sala de lo Social Audiencia Nacional no 00166/2017, de 17 de noviembre de 2017 (Ponente: R. BODAS MARTÍN; número de recurso: 277/2017), indicó, como resumen, lo siguiente: "La naturaleza jurídica de las relaciones entre los socios trabajadores de las sociedades cooperativas de trabajo asociado no es laboral ni se rige por el Estatuto de los Trabajadores. Así, dado que no se trata propiamente de trabajadores por cuenta propia, sino de socios de la cooperativa, no pueden afiliarse a sindicatos de trabajadores" (Fuente: VLex España). También véase, en general, la página web del Ministerio de Trabajo, Migraciones y Seguridad Social: "Guía laboral. El trabajo por cuenta propia o autónomo y el trabajo asociado": http://www.mitramiss.gob.es/es/Guia/texto/guia_2/contenidos/guia_2_7_2.htm (última consulta: 25 abril 2019).

${ }^{200}$ BOE n $^{\circ} 50,27$ febrero 1996 (BOE-A-1996-4447).

201 Artículo 8.1.

${ }^{202}$ Vid. FOLGADO, L.: “¿Qué protección tienen los socios trabajadores de las cooperativas ante una crisis empresarial?”. Blog Fevecta, 11 marzo 2019.

${ }^{203}$ Ídem. Artículo 2.1 del Real Decreto 1043/1985 y artículo 1 del Real Decreto 42/1996. ISSN: 2174-6419 Lex Social, vol. 9, núm. 2 (2019)
} 
derecho al cese de actividad, como contingencia que es de obligada cotización, en atención al Real Decreto Ley 28/2018 ${ }^{204}$. Las causas en este otro caso también serían por la expulsión improcedente; la finalización del período de vinculación de duración determinada de la socia con la sociedad; el fin del período de prueba; la fuerza mayor; o los motivos económicos, técnicos, productivos u organizativos que encaminasen a la cooperativa hacia la inviabilidad de su actividad $^{205}$.

Había sido el Real Decreto 1043/1985 ${ }^{206}$ el que se había encargado de ampliar la protección por desempleo a las socias trabajadoras de las cooperativas de trabajo asociado; así como luego el Real Decreto 42/1996 ${ }^{207}$. Los artículos 1 de ambos Reales Decretos indicarían (en masculino, que, una vez más, feminizamos) el derecho a las prestaciones por desempleo de las socias trabajadoras de las cooperativas de trabajo asociado "incluidas en el régimen general de la Seguridad Social o en alguno de los regímenes especiales que protegen la contingencia por desempleo".

En concordancia con todo lo anterior, el artículo 14.1 del TRLGSS ${ }^{208}$ indica en su apartado primero la citada opción que tiene la cooperativa de trabajo asociado de dar de alta a las socias como trabajadoras autónomas en el régimen especial o como asimiladas a las trabajadoras por cuenta ajena. De ejercitar esta última opción, la cooperativa quedaría integrada "en el régimen general o en alguno de los regímenes especiales de la Seguridad Social, según proceda, de acuerdo con su actividad", conforme al tenor literal de su letra a). La duda que pudiera despertar una veloz lectura de esta última oración es si, entonces, quedaría integrada en el régimen especial de las empleadas de hogar del régimen general de la Seguridad Social donde -se recuerda- no se contempla el desempleo. La anterior duda se despeja atendiendo al artículo 2 del Real Decreto 1620/2011, y en virtud de la disposición adicional decimoséptima de la Ley 27/2011, de 1 de agosto, sobre actualización, adecuación y modernización del sistema de Seguridad Social, sobre la "prestación de servicios domésticos a través de empresas": cuando media una empresa (en este caso, una cooperativa) el alta es en el régimen general de la Seguridad Social por cuenta de la empresa, en vez de en el régimen especial de las empleadas del hogar. Este último solo está previsto para las empleadas de hogar que realizan una actividad individual y, en consecuencia, no para quienes lo realizan de forma colectiva como socias trabajadoras de una cooperativa. La cooperativa ni puede optar ni puede quedar integrada en el régimen especial de las empleadas del hogar.

Algunas de las cooperativas de trabajo asociado que ya han sido constituidas por mujeres dedicadas a los servicios del cuidado y la ayuda al domicilio han venido

\footnotetext{
${ }^{204}$ BOE n $^{\text {o } 314, ~} 29$ diciembre 2018 (BOE-A-2018-17992).

${ }^{205}$ Vid. FOLGADO, L.: “¿Qué protección...?”, op. cit.

206 BOE no 157, 2 julio 1985 (BOE-A-1985-12675).

${ }^{207} \mathrm{BOE} \mathrm{n}^{\circ} 42,17$ febrero 1996 (BOE-A-1996-3553).

${ }^{208}$ Como anteriormente la Disposición adicional cuarta de la (derogada) Ley general Seguridad Social, que fue aprobada por el Real Decreto Legislativo 1/1994 (BOE nº 154, 29 junio 1994 [BOE-A-199414960]). 
destacando ${ }^{209}$ cómo "en su calidad de socias-trabajadoras, logran la equiparación total de derechos al régimen de Seguridad Social", superando las cooperativistas los obstáculos y límites (como el no otorgamiento del derecho al desempleo) que hay para las trabajadoras del hogar que realizan una actividad individual (y no colectiva, como cooperativistas) en el régimen especial del servicio doméstico incluido en el régimen general de la Seguridad Social.

Sin especialidad para las cooperativistas no habría para ellas la discriminación a la que aludíamos y que criticábamos al inicio de este texto. Subsiste, no obstante, otra especialidad: no resultan aplicables a las cooperativas de trabajo asociado las "normas sobre cotización y prestaciones del Fondo de Garantía Salarial", según el apartado tercero del artículo 14 del TRLGSS. Aunque habría una prestación por desempleo, no habría la correspondiente al FOGASA, por la que no cotizarían. Tiene el Gobierno la facultad de adaptación de las reglas de los regímenes de la Seguridad Social a las particularidades de la actividad cooperativa, a tenor del apartado cuarto del mismo artículo. Aun así, quisiéramos mostrar nuestra disconformidad con la exclusión de la prestación del Fondo de Garantía Salarial porque, a nuestro entender, debieran tener derecho al conjunto de las prestaciones, sin exclusiones.

Aparte de la cobertura al desempleo para aquellas trabajadoras del hogar que sean cooperativistas (de una cooperativa de trabajo asociado), hay que anotar que cuando la cooperativa (de cualquier clase, también la de trabajo asociado) haya optado en sus estatutos por el régimen de Seguridad Social de las trabajadoras por cuenta ajena, serán aplicables los incentivos que para la incorporación de trabajadoras dispone la Ley de Economía Social en el artículo 9.1. Son bonificaciones en las cuotas empresariales de la Seguridad Social durante tres años ${ }^{210}$ por la incorporación de trabajadoras desempleadas como socias trabajadoras (o de trabajo, cuando la cooperativa no sea de trabajo asociado) menores de treinta años, o menores de treinta y cinco años con un grado de discapacidad reconocido igual o superior al $33 \%^{211}$. El siguiente precepto habla, además, de la "capitalización de la prestación por desempleo a las beneficiarias de

\footnotetext{
${ }^{209}$ Como destacara, el 30 de enero de 2012, en su página web la cooperativa de trabajo asociado en el sector doméstico "Work-Lan Bizcaia", bajo el título: "Las cooperativas de trabajo asociado de mujeres del servicio de ayuda a domicilio, una alternativa con numerosas ventajas", que: "En su calidad de sociastrabajadoras, logran la equiparación total de derechos al régimen general de Seguridad Social, frente a la nueva regulación estatal, que establece unos límites como trabajadoras autónomas en las cotizaciones sociales [...], y no les otorga el derecho al desempleo. Unos obstáculos que sí son superados por las cooperativistas". En este sentido, en la web de Zaintza ("Empleo en servicio doméstico"): http://www.servicio-domestico.org/?ServicioDomestico=noticias\&noticias_Id=75 (última consulta: 25 abril 2018), se informaba (en la noticia rubricada: "Empleadas de hogar y socias"), a 12 de marzo de 2012, que: "La creación de cooperativas de ayuda a domicilio soluciona muchos problemas de las trabajadoras. [...] Logran la equiparación total de derechos al régimen general de Seguridad Social, frente a la [...] regulación estatal de 2012, que establece límites en las cotizaciones sociales y no otorga el derecho al desempleo".

${ }^{210}$ La cuantía de la bonificación de la cuota empresarial asciende a 137,5 euros/mes (1.650 euros/año) durante el primer año, y a 66,67 euros/mes (800 euros/año) durante los dos siguientes años.

${ }^{211} \mathrm{Si}$ la incorporación es de trabajadoras mayores de treinta años, la bonificación es de 66,67 euros/mes (800 euros/año) durante el período trienal.
} 
prestaciones cuando pretendan incorporarse como socias trabajadoras o de trabajo en cooperativas".

La aplicabilidad de las reglas del régimen general de la Seguridad Social en iguales términos y condiciones que a los demás colectivos a los que les son aplicables y, asimismo, las bonificaciones laborales por la incorporación de trabajadoras conforman una pieza clave a la que atender y por la que decantarse en la toma de decisión por parte de las trabajadoras del hogar de constituir o integrar una cooperativa, en el caso recomendado, de trabajo asociado.

También podrían ser tenidos en cuenta para la toma de la decisión final de trabajar mediante una cooperativa los beneficios fiscales a los que puede accederse. De conformidad con los artículos 33 y 34 de la Ley 20/1990, de 19 de diciembre, sobre el régimen fiscal de las cooperativas ${ }^{212}$, puede acceder a incentivos fiscales una cooperativa de trabajo asociado considerada como "especialmente protegida" por cumplir los siguientes tres requisitos del artículo 8: primero, que se asocien personas físicas que presten su trabajo personal en la cooperativa para la producción de bienes o servicios para terceros (como sería el caso de la prestación de servicios de cuidados y de tareas del hogar); segundo, que el importe medio de las retribuciones totales devengadas no exceda del $200 \%$ de la media de las retribuciones normales en el sector de actividad (en este caso, del hogar); y, tercero, que el número de trabajadoras asalariadas con contrato por tiempo indefinido (no socias) no exceda del $10 \%$ del total de socias, aunque si el número de socias fuese inferior a diez podría contratarse a una trabajadora asalariada. Teniendo esta consideración de protección especial por cumplir estas tres condiciones, los beneficios tributarios previstos serían los que enuncian en coordinación aquellos artículos 33 y 34: el disfrute de una bonificación del 50\% de la cuota íntegra del Impuesto sobre Sociedades; otra bonificación del 95\% de la cuota y, en su caso, de los recargos del Impuesto sobre Actividades Económicas; y una exención en el Impuesto sobre Transmisiones y Actos Jurídicos Documentados (ITPyAJD) por los actos de constitución, de ampliación de capital, o de modificaciones estructurales (fusión y escisión); por la constitución y la cancelación de préstamos; por las adquisiciones de bienes y derechos integrados en el fondo de educación y promoción; y por la adquisición de bienes y derechos destinados al cumplimiento de los fines sociales y estatutarios. No cumpliéndose, en cambio, aquellas tres condiciones, la cooperativa de trabajo asociado dejaría de ser especialmente protegida para pasar a ser protegida, en cuyo caso los incentivos serían los mismos, con esta doble excepción ${ }^{213}$ : no habría exención en el ITPyAJD por la adquisición de bienes y derechos para el cumplimiento de los fines sociales y estatutarios; y en el Impuesto sobre Sociedades a la base imponible correspondiente a los resultados cooperativos (es decir, los derivados de las actividades cooperativizadas con los socios) se le aplicaría el tipo del 20\%, siendo

\footnotetext{
212 BOE n ${ }^{\text {o } 304, ~} 20$ diciembre 1990 (BOE-A-1990-30735).

${ }^{213}$ En la relación del artículo 33 con el 34 de la Ley 20/1990. ISSN: 2174-6419
} Lex Social, vol. 9, núm. 2 (2019) 
aplicable el tipo general a la base imponible de los rendimientos extra-cooperativos, esto es, los derivados de las actividades cooperativizadas con los terceros.

\subsection{Cooperativa de trabajo de iniciativa social para la emprendedora del hogar.}

Los incentivos fiscales antedichos son también para la constitución y el funcionamiento de una cooperativa de trabajo de iniciativa social (CTIS), como idóneo formato para desenvolver el emprendimiento cooperativo en el sector del trabajo doméstico ${ }^{214}$. A una cooperativa de iniciativa social le resultan aplicables las normas relativas a la clase de cooperativa a la que pertenezca. La de iniciativa social no sería propiamente un nuevo tipo cooperativo, en tanto ha sido entendido "como especialidad de cualquier tipo de cooperativa dentro de las clasificaciones que se contemplan legislativamente" 215 . Las cooperativas de iniciativa social pueden ser, por ende, subtipos de cualquier tipo de cooperativa, aunque la praxis luego las cercene entre las de trabajo asociado, las de consumo o las de servicios ${ }^{216}$; y sean las de trabajo asociado las que interesen a efectos de las labores del hogar. En consecuencia, de ser la cooperativa de iniciativa social una cooperativa de trabajo asociado, las reglas enunciadas en el apartado previo procedentes de los artículos 80 a 87- le son de aplicación, en virtud de la remisión del artículo 106.3 de la Ley estatal.

Rasgo identificativo de la cooperativa de trabajo de iniciativa social es la ausencia del ánimo lucrativo ${ }^{217}$. Aun cuando la naturaleza jurídica de la cooperativa como sociedad $^{218}$ conllevaría implícito el ánimo de lucro en una concepción societaria tradicional, su falta no obsta al carácter societario cooperativo ${ }^{219}$. Carece de lucro la de iniciativa social y por esta carencia se alza en ejemplo de cooperativa capaz de encuadrar al sector doméstico para la "integración laboral de personas que sufran cualquier clase de exclusión social", como una de las finalidades que dispone el artículo 106.1 de la Ley estatal. Amén del desarrollo de actividades económicas para la integración laboral de personas con exclusión social, la cooperativa de iniciativa social sin ánimo lucrativo puede tener como objeto social la satisfacción de necesidades no cubiertas por el mercado o la prestación de servicios asistenciales (a través de actividades sanitarias, educativas o culturales), de acuerdo al mismo apartado del precepto legal indicado. En suma, servicios asistenciales, sociales o de integración laboral.

\footnotetext{
${ }^{214}$ Ejemplos destacados y recalcados de cooperativas de iniciativa social para el sector del trabajo doméstico son: "Abierto Hasta el Amanecer, S. Coop.", "TIEBEL Cooperativa de iniciativa social” o "Comala Cooperativa de servicios a domicilio".

${ }^{215}$ En las palabras literales de: ARGUDO PÉRIZ, J. L.: "Las cooperativas sin ánimo de lucro: ¿vuelta a los orígenes o respuesta a nuevas necesidades sociales?”. GEZKI, nº 3, 2007, p. 183.

${ }^{216}$ En la conclusión a la que se arriba en: Ibidem, p. 200.

${ }^{217}$ Aludido expresamente en el artículo 106.1 Ley estatal.

${ }^{218}$ Vid supra la nota a pie de página $\mathrm{n}^{\circ} 80$.

${ }^{219}$ Sobre la cooperativa como sociedad y "la relativización del lucro como elemento esencial del concepto de sociedad”, léase, por ejemplo: MORILLAS JARILLO, M. ' J.: Las sociedades cooperativas..., op. cit., pp. 35-36. También: MORILLASJARILLO, M. ${ }^{a}$ J.; FELIÚ REY, MA.: Curso..., op. cit., pp. 102 y ss. ISSN: $2174-6419$ Lex Social, vol. 9, núm. 2 (2019)
} 
En general, las cooperativas que gestionan servicios de interés colectivo o de titularidad pública o que desarrollan actividades económicas para la integración laboral de personas excluidas pueden ser calificadas como entidades sin ánimo de lucro si en los estatutos recogen expresamente los cuatro aspectos que lista la disposición adicional primera de la Ley estatal de cooperativas y que, a continuación, se transcriben (feminizando la terminología): primero, que los resultados positivos del ejercicio económico no sean distribuidos entre sus socias; segundo, que las aportaciones (obligatorias y voluntarias) al capital social no puedan devengar un interés superior al interés legal del dinero; tercero, que el desempeño de los cargos del consejo rector sea gratuito, aunque con las correspondientes compensaciones económicas por los gastos en que incurran durante el (buen) desempeño de sus funciones; y cuarto y último, que las retribuciones de las socias trabajadoras y de las trabajadoras por cuenta ajena no supere el ciento cincuenta por ciento de las retribuciones que, en función de la actividad y de la categoría profesional, establezca el convenio colectivo del personal asalariado del sector del que se trate.

\section{EMPRENDIMIENTO COLECTIVO SOCIAL CON UNA SOCIEDAD LIMITADA LABORAL.}

Para un autoempleo colectivo digno y decente dentro de la economía social y solidaria, las trabajadoras del hogar también pudieran optar por configurar o integrar una sociedad laboral, en vez de una sociedad cooperativa. El surgimiento de esta forma societaria en la década de los años sesenta y setenta fue como método de creación de empleo y, en concreto, de autoempleo colectivo de quienes trabajaban por cuenta ajena ${ }^{220}$. En el fomento del acceso y la participación de los trabajadores en los medios de producción promovido por el artículo 129 de la Constitución, la sociedad laboral encuentra un adecuado encaje. La participación de las trabajadoras del hogar en el capital social de una sociedad laboral las convertiría en socias y, en específico, en socias trabajadoras. De nuevo, las (auto)empleadas del hogar tendrían un doble papel: el de socias y trabajadoras, y la mayoría del capital habría de estar en sus manos. Las socias trabajadoras son consideradas, por el artículo 1 de la Ley $44 / 2015^{221}$ que regula a las sociedades laborales, como quienes ostentan una cuota del capital social y prestan de forma directa y personal servicios retribuidos mediante un contrato laboral por tiempo indefinido ${ }^{222}$.

\footnotetext{
${ }^{220}$ En la primera frase de la Exposición de Motivos de la Ley 44/2015.

${ }^{221}$ BOE n $^{\circ} 247,15$ octubre 2015 (BOE-A-2015-11071).

${ }^{222}$ Como antes también el artículo 1.1 de la (derogada) Ley 4/1997, de 24 de marzo, de Sociedades Laborales (BOE n $n^{\circ}$ 72, 25 marzo 1997 [BOE-A-1997-6258]), en cuyo artículo 1.1 se daba un concepto legal de la sociedad laboral en los siguientes términos: "Las sociedades anónimas o de responsabilidad limitada en las que la mayoría del capital social sea propiedad de trabajadores que presten en ellas servicios retribuidos en forma personal y directa, cuya relación laboral lo sea por tiempo indefinido". ISSN: $2174-6419$ Lex Social, vol. 9, núm. 2 (2019)
} 


\section{1. ¿Cuál es la legislación que aplicar?}

La recién nombrada ley -reguladora de las sociedades laborales en la actualidad- fue aprobada en sustitución de la Ley 4/1997 223 . La doble razón para la sustitución la refleja la Exposición de Motivos $^{224}$ : de un lado, la previa aprobación de la legislación de sociedades de capital que funciona para ellas de forma supletoria ${ }^{225}$, en tanto son sociedades de capital por su forma (anónima o limitada), además de la aprobación de otra legislación mercantil especial (la concursal, la de sociedades profesionales o la de modificaciones estructurales de las sociedades mercantiles); y, de otro lado, la potenciación de las entidades de la economía social, por caracterizarse las sociedades laborales como entidades de economía social por la Ley 5/2011226. Como sociedades (especiales) de capital por la forma y como entidades de economía social por los fines u objetivos a perseguir, las sociedades laborales, sean anónimas o limitadas, consideramos que se configuran con una naturaleza y estructura híbrida ${ }^{227}$.

La vigente regulación de las sociedades laborales declara en su Preámbulo ${ }^{228}$ cuatro pretensiones principales: aumentar, consolidar, fortalecer e incorporar. Incorporar medidas que aseguren el control de la sociedad por las trabajadoras, fortalecer la vertiente empresarial de esta sociedad, consolidar el carácter estable en el tiempo de este modelo empresarial, y aumentar la utilidad y la preferencia hacia la sociedad laboral como fórmula para la creación de empleo y autoempleo.

Para que se decanten por la sociedad laboral las trabajadoras del hogar y cuidados, tras haber dado respuesta al interrogante acerca de cuál es la legislación especial y la general supletoria aplicable, habrán de conocer cuál es el régimen jurídico tributario y laboral bonificado dirigido a animar la constitución de una sociedad laboral.

\footnotetext{
${ }^{223}$ Para ofrecer un breve repaso legislativo histórico, cabe aludir a que con anterioridad a la Ley 4/1997 regía la Ley 15/1986, de 25 de abril, de las Sociedades Anónimas Laborales (BOE nº 103, 30 abril 1986 [BOE-A-1986-10626]). La disposición derogatoria única de la Ley 4/1997 derogó esa Ley anterior para acoplarse a las novedades en aquellas fechas de la regulación tanto de la sociedad anónima (por medio de la Ley 19/1989, de 25 de julio; luego derogada) como de la sociedad de responsabilidad limitada (con la Ley $2 / 1995$, de 23 de marzo; también derogada).

${ }^{224}$ Como especifica la Ley 44/2015 en los párrafos tercero y cuarto del apartado I de su Exposición de Motivos.

${ }^{225}$ Disposición final tercera de la Ley 44/2015.

${ }^{226}$ Como recuerda el Preámbulo de la Ley 44/2015, en el párrafo quinto de su apartado I y en el primer párrafo de su apartado III.

${ }^{227}$ De "singular naturaleza jurídica" con "régimen jurídico híbrido" hablaría recientemente, por ejemplo: GARCÍA RUIZ, E.: "El régimen societario de las sociedades laborales en la nueva Ley 44/2015, de 14 de octubre, de sociedades laborales y participadas". REVESCO, $\mathrm{n}^{\circ} 123$, primer cuatrimestre 2017, pp. 69, 89. También a "híbrido societario" aludiría: PANIAGUA ZURERA, M.: "Las sociedades laborales ante el Anteproyecto de Ley del nuevo Código mercantil", en MORILLAS JARILLO, M. ${ }^{a}$ (et al.) (dirs.): Estudios sobre el futuro Código mercantil: libro homenaje al profesor Rafael Illescas Ortiz. Getafe: Universidad Carlos III de Madrid, 2015, p. 734; quien, en las notas a pie de página 45 y 47, recogió las diversas "construcciones doctrinales" que consideran a la sociedad laboral bien como sociedad de capital especial o bien como un híbrido a mitad de camino entre las capitalistas y las mutualistas.

${ }^{228}$ Según los párrafos primero y segundo del apartado III del Preámbulo. 
Los incentivos fiscales que rigen para ellas se reducen a una bonificación del 99\% de las cuotas devengadas en el ITPyAJD por la modalidad de transmisiones patrimoniales onerosas, por la adquisición de bienes y derechos. Esta última bonificación está contenida en el artículo 17 de la Ley de Sociedades Laborales, donde se especifica que es para "la adquisición de bienes y derechos provenientes de la empresa de la que proceda la mayoría de los socios trabajadores de la sociedad laboral". Tal especificación entiende la doctrina que redunda en que este "beneficio fiscal [sea] escasamente operativo" porque el "legislador está pensando en la creación de una sociedad a partir de una empresa anterior" 229.

Porque este incentivo fiscal no halla operativa práctica, hay que decir e incidir en que hay necesidad de aprobar una regulación tributaria más favorable, que sí existe para las cooperativas y no para las sociedades laborales, aunque ambas sean entidades de la economía social. Sin un régimen tributario especial completo para las sociedades laborales se contravienen para ellas los objetivos y el mandato del artículo 129.2 de la Constitución ${ }^{230}$ de fomentar, "mediante una legislación adecuada", la participación de las trabajadoras en los medios de producción.

Aun así, hay que añadir a estos efectos fiscales una referencia a la libre amortización que el artículo 12 de la Ley 27/2014, sobre el Impuesto de Sociedades, dispone en la letra a) del apartado tercero para "los elementos del inmovilizado material [nuevos o usados], intangible e inversiones inmobiliarias" de la sociedad laboral, anónima o limitada, afectos a la realización de sus actividades, que hubieran sido adquiridos en el plazo de los primeros cinco años, a contar desde la calificación como laboral de la sociedad (y no desde su constitución).

Por lo que respecta a otros impuestos, poco puede añadirse. En la Ley 35/2006, del Impuesto sobre la Renta de las Personas Físicas ${ }^{231}$, existe una mención a las sociedades laborales en el artículo 7, sobre rentas exentas, en la letra n). Se refiere a la exención de las prestaciones por desempleo percibidas en la modalidad de pago único, pero no es una exención exclusiva de las sociedades laborales sino también de las cooperativas de trabajo asociado o de otras entidades mercantiles ${ }^{232}$. No hay un régimen tributario favorable en el IRPF para las sociedades laborales, aunque pudieran acogerse, en su caso, a los beneficios de las empresas de reducida dimensión ${ }^{233}$; como tampoco lo hay

\footnotetext{
${ }^{229}$ En las palabras - con las que concordamos- de SUBERBIOLA GARBIZU, I.: "Beneficios fiscales de las sociedades laborales en la Ley 44/2015, de 14 de octubre, de sociedades laborales y participadas". Revista Jurídica de los derechos sociales. Lex Social, vol. 7, n 2, julio-diciembre 2017, pp. 118 y 120 ; quien lo califica de beneficio fiscal "escasamente operativo" y "extremadamente limitado". En el mismo sentido, se había pronunciado la profesora en otro estudio suyo sobre los beneficios fiscales contenidos en la anterior Ley de Sociedades Laborales: SUBERBIOLA GARBIZU, I.: "Régimen tributario de las sociedades laborales". Revista Vasca de Economía Social, n 10, 2013, pp. 7-52.

${ }^{230}$ Vid. SUBERBIOLA GARBIZU, I.: "Beneficios fiscales...”, op. cit., pp. 123, 125.

${ }^{231} \mathrm{BOE} \mathrm{n}^{\circ} 285,29$ noviembre 2006 (BOE-A-2006-20764).

${ }^{232}$ Vid. SUBERBIOLA GARBIZU, I.: "Beneficios fiscales...", op. cit., p. 125.

${ }^{233}$ Ibidem, p. 123.
} 
en los impuestos sobre el patrimonio o sobre el valor añadido. No lo hay; pero, a nuestro parecer ${ }^{234}$, lo debiera haber.

No habiendo apenas incentivos fiscales, quizás sean los incentivos laborales los que pudieran avivar la decisión de constitución de una sociedad laboral por parte de la trabajadora del hogar. Se hallan en los artículos 9 y 10 de la Ley de Economía Social. Son bonificaciones para la incorporación de trabajadoras a las entidades de la economía social, válidos tanto para las cooperativas como para las sociedades laborales. Se recuerda que son para la incorporación de socias trabajadoras menores de treinta años, o menores de treinta y cinco años con discapacidad igual o superior al treinta y tres por ciento $^{235}$. Como comentábamos para las cooperativas, también el artículo 10 de esta Ley de Economía Social se refiere a la capitalización de la prestación por desempleo a los beneficiarios de prestaciones cuando pretendan incorporarse como socias trabajadoras de una sociedad laboral.

Aparte de dar a conocer los incentivos laborales, conviene identificar cuál es el régimen aplicable de la Seguridad Social ${ }^{236}$. A la socia, miembro o no del órgano de administración, que no realice funciones de dirección ni gerencia se le aplicará el régimen general de la Seguridad Social ${ }^{237}$ con plena cobertura de todos los derechos, incluido el desempleo. A la socia que sea consejera o administradora y ejerza funciones retribuidas de dirección y gerencia o que tenga una relación especial de alta dirección se le aplicará el régimen asimilado al de la trabajadora por cuenta ajena ${ }^{238}$, con exclusión en este caso tanto de la prestación de desempleo como de FOGASA; salvo que la sociedad laboral tuviera un número inferior a veinticinco socias, en cuyo caso, de nuevo, se aplicaría el régimen general sin especialidad y, en consecuencia, con total cobertura. De una regla más se ha de informar: la integración no será en el régimen general sino en el especial de autónomas cuando se posea el control directo o indirecto de la sociedad. El artículo 305.2.b) TRLGSS detalla los supuestos en que se presume (en presunción iuris tantum) que la trabajadora posee el control efectivo de la sociedad por la concurrencia de una de las tres circunstancias siguientes: primero, que, como mínimo, la mitad del capital de la sociedad para la que preste los servicios esté distribuido entre socias con quienes conviva y con quienes se encuentre unida por un vínculo de parentesco o conyugal hasta el segundo grado; segundo, que su participación en el capital sea igual o superior a la tercera parte del total; y, tercero, que su participación en el capital sea como mínimo igual a la cuarta parte del total si tuviera atribuidas las funciones de dirección o gerencia. En suma, de tener el control efectivo directo o indirecto en los términos legales expuestos o de ejercer funciones retribuidas de dirección o gerencia o prestar otros servicios para la sociedad a título lucrativo de

\footnotetext{
${ }^{234}$ También en el parecer de la profesora SUBERBIOLA GARBIZU (Ibidem, pp. 124, 128).

${ }^{235}$ Véase supra la nota a pie de página $\mathrm{n}^{\circ} 211$.

${ }^{236}$ Artículo 305 TRLGSS. Vid. PANIZO ROBLES, J. A.: "La Seguridad Social de los socios de las sociedades laborales y participadas. (Con ocasión de la Ley 44/2015, de 14 de octubre)". CEF-Laboral Social, octubre 2015, pp. 7-9.

${ }^{237}$ Artículo 136.2.b) TRLGSS.

238 Artículo 136.2.c) TRLGSS.
} 
modo habitual, directo y personal, el régimen de la Seguridad Social no será el general, sino el asimilado o el especial de autónomas.

\section{2. ¿Cómo y dónde registrar?}

Además del régimen fiscal y laboral, interesaría a la empleada del hogar averiguar el régimen societario antes de la elección final entre una cooperativa o una sociedad laboral. Dicha averiguación pudiera comenzar - para continuar con la sistemática de la descripción de la cooperativa- por el "cómo" y el "dónde" del registro.

Para constituir una sociedad laboral, anónima o limitada ${ }^{239}$, a los trámites generales para la constitución de cualquier sociedad mercantil (escritura pública más inscripción en el Registro Mercantil provincial del domicilio social) se ha de adicionar una calificación y un registro administrativo del carácter laboral, con carácter previo a la inscripción en el correspondiente Registro Mercantil provincial correspondiente al domicilio social. Se trata del registro administrativo de la Dirección General del Trabajo Autónomo, de la Economía Social y de la Responsabilidad Social de las Empresas del Ministerio de Trabajo, Migraciones y Seguridad Social ${ }^{240}$ o, en su caso, del órgano competente de la respectiva Comunidad Autónoma con competencias transferidas en esta materia, conforme al artículo 2. Transferidas están estas funciones en todas las Comunidades Autónomas, aunque no así en las ciudades autónomas de Ceuta y Melilla. Para la inscripción en el Registro Mercantil, a efectos de gozar de personalidad jurídica ${ }^{241}$, habrá, por tanto, de aportarse un certificado otorgado por el Ministerio o por las Comunidades Autónomas sobre la calificación como sociedad laboral

El registro administrativo controla el cumplimiento por parte de la sociedad de los requisitos para la adquisición o, en caso contrario, la pérdida ${ }^{242}$ de la calificación laboral. Para la adquisición de tal calificación será necesaria la reunión de tres requisitos legales. Primero, que la mayoría del capital social sea propiedad de trabajadoras que presten servicios retribuidos en virtud de una relación laboral por tiempo indefinido.

\footnotetext{
${ }^{239}$ Desde la Ley de 1997 hasta la actualidad la sociedad laboral puede ser anónima o limitada (art. 1), a diferencia de lo que ocurría con la primigenia Ley de 1986 que restringía la regulación a la sociedad anónima laboral. Sobre la sociedad anónima laboral, léase, por todos: LLOBREGAT HURTADO, M. ${ }^{a}$ L.: "Reflexiones sobre el régimen jurídico de las sociedades anónimas laborales...", op. cit., pp. 123-142.

${ }^{240}$ El registro administrativo de sociedades laborales se regula en el Real Decreto 2114/1998, de 2 de octubre (BOE n ${ }^{\circ} 246,14$ octubre 1998 [BOE-A-1998-23789]).

${ }^{241}$ Artículo 4.2 de la Ley de Sociedad Laboral.

${ }^{242}$ Es el artículo 15 el que alude a la pérdida de calificación de la sociedad como laboral. El primer motivo sería cuando el número de horas-año trabajadas por trabajadoras que no sean socias fuera superior al $49 \%$ de las horas-año trabajadas por las socias trabajadoras durante más de doce meses. No obstante, el registro administrativo podría conceder dos prórrogas de doce meses cada una de ellas, si se acreditara el avance hacia la reducción del límite de horas-año excedido. Segundo, cuando alguna socia excediera su participación en más de un tercero del capital de la sociedad. Para la supresión de este exceso la sociedad contaría con un plazo de 18 meses. Tercero, cuando hubiera una ausencia, una insuficiencia o una indebida aplicación del fondo de reserva especial. Además, cuando en junta general se acordare solicitar la pérdida de tal calificación como laboral (art. 15.4).
} 
Segundo, que ninguna socia posea participaciones sociales (o, en caso de sociedad anónima laboral, acciones) que representen más de un tercio del capital social. Esta exigencia implícita a un número mínimo de tres socias no debiera verse como un impedimento para la constitución de una sociedad laboral sino como un aliciente para el emprendimiento colectivo que conlleva un incremento del empoderamiento económico. Este número mínimo de socias cuenta con excepciones legales especiales ${ }^{243}$. Si al inicio fuesen solo dos las trabajadoras domésticas interesadas en constituir una sociedad laboral podrían constituirla, contando con un plazo de treinta y seis meses añadidos para encontrar a una tercera trabajadora doméstica interesada en convertirse en la tercera socia trabajadora. La segunda excepción no parece ser en este caso de tanto interés, aun cuando se comenta para su conocimiento general. Se refiere a posibles socios inversores que, en caso de estar interesados en invertir, acrecentarían los recursos económicos de la sociedad laboral ${ }^{244}$. En el supuesto de que hubiera socios inversores que fueran entidades públicas (o de capital mayoritariamente público), entidades no lucrativas u otras entidades de la economía social, su participación podría superar el tercio, aun cuando nunca alcanzar la mitad del capital. La tercera, no excepción sino condición legal para la calificación de la sociedad como laboral, es que el número de horas al año trabajadas por las socias trabajadoras en su conjunto habrá de ser superior al número de horas al año trabajadas por las trabajadoras contratadas por tiempo indefinido que no sean socias. En específico, el total de horas al año trabajadas por las trabajadoras no socias no podrá superar el $49 \%$ del total de horas al año trabajadas por las trabajadoras socias $^{245}$. Téngase en cuenta que en este porcentaje no se tomarían en consideración las trabajadoras que tuvieran una discapacidad igual o superior al treinta y tres por ciento. No alcanzando la sociedad anónima o limitada uno o varios de los requisitos antedichos no podría ser calificada como laboral, pero sí como sociedad participada por los trabajadores en el caso de que se promoviera el acceso a la condición de socias de las trabajadoras, según dispone el artículo 19 de la Ley 44/2015 cuyo análisis nos detiene en este epígrafe.

Una vez explicada la doble inscripción registral en tramitación presencial para la constitución de una sociedad laboral, hay que anotar que, si atendiéramos al Real Decreto (también) 44/2015, de 2 de febrero, por el que se regulan las especificaciones y

\footnotetext{
243 Artículo 1.2 de la Ley de Sociedad Laboral.

${ }^{244}$ Vid. GARCÍA RUIZ, E.: “El régimen societario de las sociedades laborales...”, op. cit., p. 72.

${ }^{245}$ Inferior era el porcentaje que establecía la Ley de 1997 en su artículo 1.2: el número de horas al año trabajadas por las trabajadoras con contrato indefinido no socias no podía ser superior al $15 \%$ del total de horas al año trabajadas por las trabajadoras indefinidas socias, salvo que el número de trabajadoras socias fuese menor de veinticinco, en cuyo caso era del 25\%. Como comentara GARCÍA RUIZ, E.: "El régimen societario de las sociedades laborales...", op. cit., p. 74, la nueva legislación "admite un aumento importante del volumen de horas año trabajados por los trabajador[a]s por tiempo indefinido no soci[as]" y "esta medida no ayuda a preservar la nota de laboralidad connatural a la naturaleza de este tipo social y acerca su régimen jurídico al de las sociedades de capital". En este sentido, el Dictamen 6/2015 del Consejo Económico Social, sobre el Anteproyecto de Ley de Sociedades Laborales, indicaría que esta alteración de los porcentajes, aunque "puede contribuir a facilitar el funcionamiento de las sociedades laborales", también podría "afectar al concepto de sociedad laboral" por "entrar en colisión con los principios sustanciales sobre los que se sustenta".
} 
condiciones para el empleo del Documento Único Electrónico (DUE), las sociedades limitadas laborales y las sociedades cooperativas podrían constituirse mediante un sistema de tramitación telemática ${ }^{246}$ para ganar en agilidad y en reducción de costes en el proceso de inscripción.

La Estrategia Española de la Economía Social 2017-2020 subraya en su segundo objetivo específico que se "da un primer paso hacia la digitalización del sector [cooperativo] con la habilitación del registro telemático de cooperativas de ámbito estatal". Entre las medidas de su segundo eje sobre el "impulso a la consolidación de empresas de economía social y su crecimiento", se matiza que "se procederá a habilitar un registro telemático de cooperativas de ámbito estatal", "con el fin de eliminar trabas administrativas y agilizar la relación entre los ciudadanos y el registro de cooperativas". No nos consta que se haya habilitado de manera generalizada. Así, por ejemplo, mientras en la página web del Registro de Cooperativas de Andalucía consta que puede solicitarse y tramitarse en línea ${ }^{247}$, en la web del Registro de Cooperativas de la Comunidad de Madrid consta que: "La presentación de la documentación que acompaña a la solicitud, temporalmente, hasta la completa implantación de la tramitación electrónica en el Registro de Cooperativas, se efectuará de forma presencial"248.

En la práctica el sistema de tramitación telemática de sociedades CIRCE $^{249}$ no está operativo para las laborales. Aun cuando haya independencia entre los ámbitos de calificación de la sociedad laboral por parte del registro administrativo (del Ministerio de Trabajo o de la Comunidad Autónoma) y del Registro Mercantil -calificando los aspectos laborales la autoridad administrativa y los societarios la autoridad registral mercantil ${ }^{250}$-, el Registro Mercantil provincial no puede proceder a la inscripción de la sociedad en tanto no haya sido calificada y registrada previamente como laboral por la autoridad administrativa regional o estatal competente ${ }^{251}$; y el sistema de tramitación telemática de una sociedad mercantil de capital (en específico, de una sociedad de responsabilidad limitada) está pensado para el envío directo de la escritura pública de

\footnotetext{
${ }^{246}$ BOE n $^{\circ} 36,11$ febrero 2015 (BOE-A-2015-1320).

247 https://www.juntadeandalucia.es/servicios/procedimientos/detalle/633/como-solicitar.html (última consulta: 25 abril 2019).

248

http://www.madrid.org/cs/Satellite?c=CM_Tramite_FA\&cid=1109168978905\&pagename=ComunidadM adrid\%2FEstructura (última consulta: 25 abril 2019).

${ }^{249}$ El CIRCE es el Centro de Información y Red de Creación de Empresas del Ministerio de Industria, Comercio y Turismo. Es un sistema para la realización telemática de los trámites de constitución de una sociedad. Se configura como una red de PAE o Puntos de Atención al Emprendedor: Hasta la fecha no está abierto ni para las sociedades limitadas laborales ni para las sociedades cooperativas. http://www.paeelectronico.es/es-ES/Paginas/principal.aspx (última consulta: 25 abril 2019).

${ }^{250}$ Véase la nota a pie de página $\mathrm{n}^{\circ} 39$ del siguiente estudio: JORDÁ GARCÍA, R.: "Empresas de economía social y constitución telemática de sociedades “, en PARDO LÓPEZ, M. a M.; GÓMEZ MANRESA, M. ${ }^{\mathrm{a}}$ F.: Economía social y derecho. Problemas jurídicos actuales de las empresas de economía social. Granada: Comares, 2013, p. 129; citando, en el mismo sentido, a: VALPUESTA GASTAMIZA, E. M.a; BARBERENA BELZUNCE, I.: Las sociedades laborales. Aspectos societarios, laborales y fiscales. Pamplona: Aranzadi, 1998, pp. 50-53.

${ }^{251}$ Vid. JORDÁ GARCÍA, R.: "Empresas de economía social...”, op. cit., p. 129 ISSN: 2174-6419 
constitución al Registro Mercantil ${ }^{252}$ sin la intermediación de pasos registrales previos. $\mathrm{Al}$ anterior impedimento (no insalvable) se añade el hecho de que el modelo de estatutos sociales orientativo, desarrollado por el Real Decreto de 29 de mayo de $2015^{253}$ para facilitar y agilizar la tramitación electrónica de una sociedad limitada, no contempla especialidades para la sociedad limitada laboral y esta tiene especialidades (que debieran haberse recogido en ese modelo-tipo de estatutos) en lo relativo a las clases (laboral y general) en que se dividen las participaciones sociales, a la abreviatura de la denominación social, a la dotación y destino de la reserva legal, o al derecho de suscripción preferente ${ }^{254}$. Aun cuando sea cierto que también está prevista la constitución electrónica de una sociedad limitada sin estatutos tipo (con estatutos personalizados) y pudiera ser, por tanto, factible la vía de la constitución electrónica para una sociedad limitada laboral sin haber (como no hay) para ellas un modelo de estatutos ajustado a sus peculiaridades, recalcamos que en la práctica no prevé el sistema telemático CIRCE la posibilidad de crear una empresa "online" con formato laboral $^{255}$. Lo que sí es electrónico, en cambio, es la solicitud de la calificación y del registro como sociedad laboral en el registro administrativo de la Comunidad Autónoma $^{256}$. Siendo posible en el presente solicitar la calificación y el registro laboral por medios electrónicos, confiemos que en el futuro sea posible realizar toda la tramitación por estos medios para que la práctica y la teoría (del BOE que publicó aquel Real Decreto 44/2015) estén por fin alineadas.

\section{3. ¿Cuánto es el coste y cuál es la responsabilidad?}

Para decidir constituir (necesariamente presencialmente) una sociedad laboral no habrán de ignorar las empleadas del hogar qué responsabilidad asumirán y cuánto dinero les costará. La responsabilidad estará restringida a la cantidad económica aportada, sea en una sociedad anónima o en una sociedad limitada, en ambos casos, laboral. No existiendo diferencias en cuanto a la responsabilidad, el dilema entre una y otra sociedad laboral se centrará (no solo) en el monto del capital social. En la disyuntiva entre suscribir y desembolsar un capital social mínimo de tres mil euros para la sociedad limitada laboral y de sesenta mil para la sociedad anónima laboral, aun con posibilidad en este último caso de desembolso de una cuarta parte del valor nominal de cada una de las acciones, la empleada del hogar (generalmente con escasos recursos económicos) muy probablemente se decantará por la primera de las opciones anunciadas; como se decantan en la práctica la mayoría de quienes deciden emprender por medio de una

\footnotetext{
252 Ídem.

${ }^{253}$ Como el anterior desarrollado por el Real Decreto-Ley 13/2010, de 3 de diciembre, de actuaciones en el ámbito fiscal, laboral y liberalizadoras para fomentar la inversión y la creación de empleo (BOE $\mathrm{n}^{\circ} 293$, 3 diciembre 2010 [BOE-A-2010-18651]).

${ }^{254}$ Como bien explicara: JORDÁ GARCÍA, R.: "Empresas de economía social...”, op. cit., p. 130

${ }^{255} \mathrm{http}$ ://www.paeelectronico.es/es-ES/CreaEmpresa/Paginas/CreaEmpresaOnline.aspx (última consulta: 25 abril 2019).

256
}

http://www.madrid.org/cs/Satellite?c=CM_Tramite_FA\&cid=1109168966993\&definicion=Inscripcion+

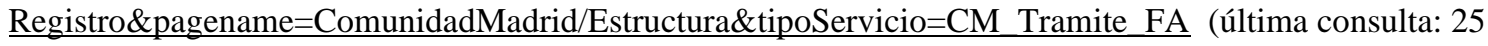
abril 2019). 
sociedad laboral ${ }^{257}$. En consecuencia, es a esta opción a la que a partir de estas líneas se prestará atención.

El capital social de la sociedad limitada laboral habrá de estar dividido en participaciones sociales que, a su vez, se dividirán ${ }^{258}$ en una clase laboral y una clase general. La clase laboral será propiedad de las trabajadoras con contrato laboral por tiempo indefinido. La clase general será un cajón de sastre donde hallarán sitio todas las demás. De una u otra clase, las participaciones tendrán idéntico valor nominal e iguales derechos económicos y contarán siempre con derecho de voto para que no existan diferencias entre la propiedad del capital y el control de la sociedad ${ }^{259}$. Cuando siendo participaciones de clase laboral, a la socia trabajadora se le extinga el contrato laboral, habrá de ofrecer (en régimen de transmisión forzosa) ${ }^{260}$ en el plazo máximo de un mes la adquisición de sus participaciones sociales conforme al régimen jurídico de la transmisión voluntaria que, acto seguido, se enunciará; no sin antes anunciar que, si nadie ejercitara el derecho de adquisición preferente, aquella socia a la que se le extingue el contrato laboral (antes socia trabajadora con participaciones de la clase laboral) permanecería en la sociedad laboral como socia con participaciones de la clase general.

En el régimen jurídico de la transmisión voluntaria de las participaciones sociales por actos inter vivos, la libre transmisibilidad a las socias trabajadoras (con contrato laboral indefinido) o a las trabajadoras no socias con contrato laboral indefinido es la regla general, salvo disposición estatutaria en contrario ${ }^{261}$. En otros supuestos, la restricción sustituye a la libertad. La restricción se concreta en la comunicación a la sociedad del número y de las condiciones de las participaciones sociales que pretendan transmitirse. Con el ánimo siempre presente de la preservación de la calificación como laboral de esta sociedad limitada, la sociedad trasladará la pretensión de transmisión a las socias (trabajadoras y generales) y a las no socias, pero sí trabajadoras con contrato indefinido, para que puedan, si lo desean, ejercitar un derecho de adquisición preferente. En la hipótesis de que varias lo desearan ejercitar, este derecho tendría el siguiente orden legal de preferencia ${ }^{262}$ : las trabajadoras indefinidas no socias, por antigüedad, en primer lugar, para aumentar el número de trabajadoras que entran en la categoría de socias ${ }^{263}$; en segundo lugar, las socias trabajadoras, por relación inversa al número de participaciones que poseyeran, para no restar el número de socias trabajadoras; en tercer término, las socias no trabajadoras o socias de clase general, a prorrata de su

${ }^{257}$ En PANIAGUA ZURERA, M.: "Las sociedades laborales...", op. cit., p. 735, se recuerda que "la anónima laboral $[\ldots]$ apenas se utiliza; y la limitada laboral $[\ldots]$ tiene una mayor pujanza relativa por su mejor acomodo a las pymes".

${ }^{258}$ Artículo 5.2.

${ }^{259}$ Artículo 5.1. Vid. GARCÍA RUIZ, E.: "El régimen societario de las sociedades laborales...”, op. cit., p. 79.

${ }^{260}$ Artículo 9.

${ }^{261}$ Artículo 6.

${ }^{262}$ Artículo 6.2.

${ }^{263}$ Y "facilitar el principio democrático", añadiría GARCÍA RUIZ, E.: "El régimen societario de las sociedades laborales...", op. cit., p. 83. 
participación en el capital; y, en cuarto y último lugar, si ninguna de las anteriores hubiera ejercitado este derecho, la propia sociedad. Es el artículo 12.2 el que permite, como novedad, la adquisición (con cargo a beneficios, reserva especial o reservas disponibles) por la sociedad de sus propias participaciones sociales (en autocartera) para facilitar su enajenación en un plazo máximo de tres años a las trabajadoras con una relación laboral indefinida o, en su defecto, para su amortización, salvo que las participaciones no excedieran del $20 \%$ del capital. En todos los casos, la comunicación iría seguida del consentimiento de la sociedad o, en su defecto, de la denegación si se proporcionara una adquirente distinta. También cabría la posibilidad de una prohibición de la transmisión voluntaria por actos inter vivos en el supuesto de que hubiera un derecho de separación de la socia respecto de la sociedad en cualquier momento. Aun así, podría limitarse tanto la transmisión como la separación durante un plazo máximo de cinco años desde la constitución de la sociedad laboral.

Para la adquisición (para la posterior transmisión) de las propias participaciones sociales por la sociedad limitada laboral habrá que dotar (una vez constituida la sociedad) un fondo de reserva especial que también tendrá como destino la compensación de pérdidas si no existieran suficientes reservas disponibles. Con este doble destino es obligatorio el fondo de reserva especial -aparte de la reserva legal ${ }^{264}$ más, en su caso, las reservas estatutarias o voluntarias - integrado por el diez por ciento del beneficio líquido de cada ejercicio económico, hasta alcanzar, como mínimo, una cifra superior al doble del capital social, cuyo mínimo -se recuerda- son tres mil euros.

Una vez que conoce la empleada doméstica tanto los elementos claves de la organización financiera como la panoplia de incentivos fiscales y laborales bien pudiera decidir integrar o constituir una sociedad laboral para desenvolver económica y colectivamente las tareas del cuidado y del hogar.

\section{5.-¿EMPRENDIMIENTO COLECTIVO CON UNA SOCIEDAD DE RESPONSABILIDAD LIMITADA (DE FORMACIÓN SUCESIVA)?}

Bien pudiera, no obstante, seguir queriendo conocer otras fórmulas de emprendimiento colectivo, aunque no estén integradas en la economía social. Enfrente o, quizás, al lado del formato de la economía social, basada en la solidaridad y la sostenibilidad para ofrecer respuesta a dificultades económicas y necesidades sociales, como el desempleo, se sitúa el tradicional modelo económico donde los aspectos sociales van perdiendo protagonismo.

\footnotetext{
${ }^{264}$ Según el artículo 274 del Texto Refundido de la Ley de Sociedades de Capital: "una cifra igual al diez por ciento del beneficio del ejercicio se destinará a la reserva legal hasta que esta alcance, al menos, el veinte por ciento del capital social".
} 


\section{1. ¿Emprendimiento colectivo con una comunidad de bienes con carácter mercantil?}

En numerosas ocasiones, el aislamiento de un empresario individual no resulta suficiente o conveniente para comenzar y desarrollar una actividad empresarial. La unión de varias personas para afrontar en común una actividad económica puede ser ventajosa para el fin de obtener ganancias repartibles. La unión de dos o más trabajadoras autónomas para emprender en común pudiera establecerse mediante una comunidad de bienes ${ }^{265}$ con carácter mercantil. Resulta una "fórmula legal sencilla para el emprendimiento" 266 y "recomendable para pequeños negocios"267. Sin necesidad de aportar un capital mínimo legal, debe aportarse una cosa o derecho que será de titularidad proindiviso ${ }^{268}$ de las trabajadoras autónomas socias comuneras, y puede aportarse dinero o trabajo. Aunque pueda aportarse trabajo, no puede aportarse solo trabajo, y ni siquiera solo trabajo y capital ${ }^{269}$. Más que por este motivo, por el añadido de la responsabilidad personal, ilimitada (artículo 1911 Código Civil) y solidaria por las deudas sociales contraídas con terceros que tendrían las socias comuneras no recomendaríamos esta fórmula de emprendimiento a las trabajadoras del hogar; pese a que en la Seguridad Social estarían inmersas en el régimen especial de trabajadoras autónomas, a que tributarían por el IRPF, y a la sencillez en la gestión y en la constitución de una comunidad de bienes, mediante un contrato privado, de necesaria elevación a escritura pública solo cuando se aportaran bienes inmuebles o derechos reales, como sucede también en el caso de la sociedad civil ${ }^{270}$.

En tanto la comunidad de bienes carece de personalidad jurídica propia y aquí podría interesar más la configuración de una persona jurídica a través de la que actuar, frente a los terceros, en el tráfico económico, haremos retornar este discurso hasta las sociedades mercantiles.

\section{2. ¿Emprendimiento colectivo con una sociedad mercantil personalista?}

Conocido o por conocer entre las trabajadoras del hogar es que, entre las sociedades mercantiles de carácter general, no especial, son las sociedades personalistas -como personalistas son la sociedad colectiva o regular y la comanditaria simple o en comandita- las únicas que admiten el trabajo como aportación social. Aunque el artículo 125.4 del Código de Comercio haga mención para la escritura social al capital que cada socio aporte en dinero en efectivo, en créditos o efectos y silencie la

\footnotetext{
${ }^{265}$ Sabido es que la figura de la comunidad de bienes se regula en los artículos 392 a 406 del Código Civil.

266 Fuente: Infoautónomos: https://infoautonomos.eleconomista.es/tipos-de-sociedades/comunidad-debienes/ (última consulta: 25 abril 2019).

267 Ídem.

${ }^{268}$ Artículo 392, párrafo primero, del Código Civil.

${ }^{269}$ Fuente: Infoautónomos.

${ }^{270}$ Artículo 1667 del Código Civil. ISSN: 2174-6419 Lex Social, vol. 9, núm. 2 (2019)
} 
aportación de trabajo, aportación de las socias puede ser la prestación de un trabajo. Solo dinero (o créditos o efectos), solo trabajo o, además de dinero, trabajo.

Si solo aportara trabajo, la socia sería calificada como industrial. Como socia industrial, en el contrato social podría establecerse su exclusión de la participación en las pérdidas sociales $^{271}$. De no haber pacto contractual, para la participación en las ganancias y, conforme el artículo 140 del Código de Comercio, regiría el principio de la proporcionalidad: en proporción a la aportación, asignando a la socia industrial idénticos beneficios que a la socia capitalista (la que, en vez de trabajo, hubiera aportado capital) de menor participación. Para el supuesto de pérdidas, el precepto siguiente las imputa entre las socias capitalistas en la misma proporción que en las ganancias, excluyendo de esas pérdidas a las socias industriales, salvo si se hubiera pactado de modo expreso en contrario; pacto que no se recomendaría en el caso que ocupa nuestra atención.

Aun cuando participaran de las ganancias y pudieran no participar de las pérdidas, a las trabajadoras del hogar no les interesaría, a nuestro parecer, constituir o formar parte de una sociedad personalista, fuese colectiva o fuese en comandita, porque, aunque pudieran aportar industria o tanto bienes como industria, bajo cualquiera de estas formas sociales habrían de responder (salvo que en la sociedad comanditaria simple fueran socias comanditarias) frente a las deudas sociales contraídas con los terceros a consecuencia de la actividad empresarial con sus patrimonios personales, de manera ilimitada y solidaria, bien que de forma subsidiaria respecto del patrimonio social.

\section{3.¿Emprendimiento colectivo con una sociedad mercantil capitalista?}

Con el objetivo principal de que las trabajadoras domésticas dispuestas a emprender pudieran gozar de responsabilidad limitada a lo aportado, podrían pensar en constituir una sociedad capitalista, en vez de una sociedad personalista. Por su menor coste y su más flexible regulación, el tipo social a recomendar entre los de capital sería la sociedad de responsabilidad limitada (o sociedad limitada), excluyendo por dichos motivos tanto a la sociedad anónima como a la sociedad comanditaria por acciones.

Si por ser reducidos los recursos económicos disponibles para emprender por las trabajadoras del hogar no pudieran reunir (en aportaciones dinerarias o no dinerarias) los tres mil euros que para el capital social exige, como mínimo, el apartado primero del artículo 4 del Texto Refundido de la Ley de Sociedades de Capital, el apartado segundo facilita el emprendimiento mediante el tipo social de la sociedad de responsabilidad limitada con una cifra del capital social inferior (cualquiera inferior) a ese mínimo legal. En tal caso, el régimen aplicable sería el de formación sucesiva, incluido en el artículo 4 bis por el artículo 12.2 de la Ley 14/2013, de 27 de septiembre, de apoyo a los

${ }^{271}$ En atención a lo que dispone el artículo 1691, párrafo segundo, del Código Civil. 
emprendedores y su internacionalización ${ }^{272}$. En este régimen de formación sucesiva indica el apartado tercero del artículo 4.bis- que no sería "necesario acreditar la realidad de las aportaciones dinerarias" de las socias fundadoras porque responderían "solidariamente frente a la sociedad y frente a los acreedores sociales de la realidad de dichas aportaciones". Además, hasta alcanzar (sin plazo legal) los tres mil euros del capital social, la sociedad limitada estaría sometida a una serie de condiciones o restricciones $^{273}$. La primera sería el destino obligatorio a la reserva legal de una cifra, como mínimo, del veinte por ciento del beneficio del ejercicio económico sin límite de cuantía; mientras que la sociedad limitada si no es de formación sucesiva ha de destinar a reserva legal una cifra del diez por ciento del beneficio hasta alcanzar, al menos, el veinte por ciento del capital social, en virtud del artículo 274.1 del Texto Refundido de la Ley de Sociedades de Capital. La segunda regla para el régimen de formación sucesiva sería la siguiente: cuando hayan sido cubiertas las reservas legales o estatutarias, podrán repartirse dividendos activos a las socias en el caso de que el valor del patrimonio neto no fuera o, a consecuencia del reparto, no resultara inferior al sesenta por ciento del capital mínimo legal. Ello encuentra cobijo en el principio de correspondencia mínima entre el capital y el patrimonio. Para las sociedades limitadas (no de formación sucesiva) y, en general, las sociedades de capital, se impide, dentro de unos límites, que la cuantía del patrimonio descienda por debajo de la cifra del capital estatutario. La primera regla de ese principio es una traba para el reparto de beneficios en forma de dividendos activos. Para el reparto, el valor del patrimonio neto contable no puede ser o, a consecuencia del reparto de beneficios, no debiera ser inferior al capital $^{274}$; mientras que en la sociedad limitada de formación sucesiva no habría de ser inferior al sesenta por ciento de los tres mil euros del capital mínimo legal. Una regla especial más para este régimen de formación sucesiva es que la suma anual de las retribuciones satisfechas a las socias y las administradoras por el desempeño de sus cargos durante los ejercicios en los que la sociedad esté bajo esta modalidad especial no podrá exceder del veinte por ciento del patrimonio neto del correspondiente ejercicio, sin perjuicio de la retribución que les pudiera corresponder como trabajadoras por cuenta ajena de la sociedad o por la prestación de servicios profesionales que la sociedad concertara con las socias y las administradoras.

En una sociedad mercantil de capital y, en lo que aquí nos ocupa, en una sociedad limitada (en formación sucesiva o no), pueden prestar las socias servicios profesionales o laborales. Si las socias fuesen administradoras se admite la prestación de servicios o de obra, siempre que su establecimiento o modificación se hiciese previo acuerdo de la junta general ${ }^{275}$. Si las socias no fueran administradoras, la prestación de servicios no

\footnotetext{
272 BOE no $^{\circ} 233,28$ septiembre 2013 (BOE-A-2013-10074).

273 Artículo 4.bis. $1^{\circ}$ del Texto Refundido de la Ley de Sociedades de Capital.

${ }^{274}$ En nuestro capítulo de libro GARCÍA MANDALONIZ, M.: "El cuestionado sentido del régimen jurídico del capital social", en HIERRO ANIBARRO, S. (dir.), Simplificar el derecho de sociedades. Madrid: Marcial Pons, 2010, p. 315, añadíamos: "Escaso margen este para los administradores, quienes se ven maniatados en la crucial política para los accionistas e inversores de conseguir una adecuada remuneración mediante la distribución de beneficios".

275 A tenor del artículo 220 del Texto Refundido de la Ley de Sociedades de Capital. 
podría ser calificada como aportación sino como prestación accesoria. La prestación accesoria sería distinta de la obligación principal de realizar las aportaciones (dinerarias o no dinerarias) que integran el capital social ${ }^{276}$. No integrando la cifra del capital, estaría prohibida la entrega de participaciones sociales a la socia que realizara una prestación accesoria $^{277}$.

La regulación de las prestaciones accesorias viene marcada en el capítulo V del título III del Texto Refundido de la Ley de Sociedades de Capital, en los artículos 86 a 89. Pueden establecerse o no prestaciones accesorias y, si se establecen, han de establecerse en los estatutos sociales ${ }^{278}$. En tal caso, el establecimiento sería con carácter obligatorio para todas o algunas de las socias ${ }^{279}$. Podrían ser a título lucrativo y, de serlo, los estatutos determinarían la compensación a recibir, sin exceder del valor que correspondiera a la prestación ${ }^{280}$. Tanto la creación, como la modificación y extinción anticipada de la obligación de realizar una prestación accesoria requeriría la modificación de los estatutos más el consentimiento individual de las socias obligadas a prestarlas, conforme al apartado primero del artículo 89. Conforme a su apartado segundo, no se perdería la condición de socia por no poder llevar a cabo, por casusas involuntarias, las prestaciones accesorias, salvo disposición estatutaria contraria.

Pudiéndose llevar a cabo, podrían ser de dar, hacer o no hacer ${ }^{281}$. Una obligación de hacer sería la prestación de un servicio o una actividad. La prestación de servicios podría ser "de carácter material, técnico o administrativo"282. Las obligaciones de hacer se instrumentarían en contratos de la socia con la sociedad ${ }^{283}$. Si lo pactado como prestación accesoria es que la socia realice para la sociedad un trabajo (existiendo

\footnotetext{
${ }^{276}$ Artículo $86,1^{\circ}$ y $2^{\circ}$, del Texto Refundido de la Ley de Sociedades de Capital. Aunque el análisis sea de la normativa previa de las sociedades de responsabilidad limitada (contenida en la derogada Ley 2/1995), interesa destacar aquí dos monografías (igual tituladas) sobre el régimen jurídico de las prestaciones accesorias en esta forma social: MARTÍNEZ NADAL, A.: Las prestaciones accesorias en la sociedad de responsabilidad limitada. Barcelona: Bosch, septiembre 1997, 192 pp., y, a efectos de la definición, p. 11; VIÑUELAS SANZ, M.: Las prestaciones accesorias en la sociedad de responsabilidad limitada. Madrid: Dykinson, 2004, 371 pp.

${ }^{277}$ Vid., ad ex., MARTÍNEZ NADAL, A.: Las prestaciones accesorias..., op. p. 30.

${ }^{278}$ Artículo 86.1. Acerca de la "creación estatutaria de las prestaciones accesorias", véase ibidem, pp. 23 y ss., donde se asevera que la constancia en los estatutos es "requisito indispensable para la validez de las prestaciones accesorias como obligaciones de naturaleza social".

${ }^{279}$ Artículo 86.1, de nuevo. Con identificación personal de la socia o con vinculación a una o varias participaciones sociales y, por tanto, con independencia de quien sea la socia titular, se especificaría en: ibidem, pp. 52-53.

${ }^{280}$ Artículo 87. Las modalidades de la retribución podrían ser dar (entrega de dinero, en cantidad fija o variable), hacer o no hacer, según se comentara y desarrollara en: ibidem, pp. 77 y ss.

${ }^{281}$ Artículo 1088 del Código Civil. Aunque la mayoría de la doctrina acoge un contenido amplio, VIÑUELAS SANZ, M.: Las prestaciones accesorias..., op. cit., pp. 51 y ss., se decanta por un contenido restringido: solo hacer o no hacer, pero no dar.

${ }^{282}$ Según concretara MARTÍNEZ NADAL, A.: Las prestaciones accesorias..., op. cit., p. 62. Conforme especificara BERNING PRIETO, A. D.: "Prestaciones accesorias en la sociedad de responsabilidad limitada". Noticias jurídicas, 1 febrero 2014, el contenido más habitual serían prestaciones de "trabajo, gestión, asesoramiento, servicios jurídicos" o de "compromiso de suministrarle a la sociedad los productos que precise para su actividad" o de ejercicio por la socia como administradora social.

${ }^{283}$ Vid. VIÑUELAS SANZ, M.: Las prestaciones accesorias..., op. cit., pp. 73 y ss. 
dependencia entre la socia y la sociedad) el contrato sería laboral ${ }^{284}$. En cualquier caso, la realización de la prestación de hacer (como también la prestación de dar o no hacer) es a favor de la sociedad ${ }^{285}$, en su interés y beneficio exclusivo o en interés y en beneficio tanto de la socia como de la sociedad ${ }^{286}$. Se trata, en definitiva, de "obligaciones de contenido económico, de la que es acreedora la sociedad, por lo que forman parte del patrimonio social, pero no del capital social" 287 .

Haciendo recapitulación final, quisiéramos resaltar que las socias de una sociedad de responsabilidad limitada puedan prestar servicios a título lucrativo mediante las prestaciones accesorias, pero los prestan para la sociedad, para quien esas prestaciones suponen una ventaja económica ${ }^{288}$. El régimen de las prestaciones accesorias no está pensado para la prestación de actividades o resultados a favor de los terceros sino de la sociedad. No es, por ende, la sociedad limitada general (ni siquiera en régimen de formación sucesiva) -como tampoco las restantes sociedades de capital- una forma jurídica societaria adecuada para el desempeño externo del trabajo doméstico. En cambio, la sociedad limitada laboral sí es una fórmula idónea para la creación de empleo y autoempleo en este campo. A la limitada laboral se le aplicaría de manera supletoria -se recuerda- la regulación que para la sociedad limitada recoge el Texto Refundido de la Ley de Sociedades de Capital, en lo no dispuesto específicamente para ella en la Ley de Sociedades Laborales. Retornando al ámbito de la sociedad laboral, retornaríamos al de la economía social, donde también se cobija la cooperativa, como otra de las alternativas viables para el emprendimiento colectivo social en el sector de los cuidados y las tareas del hogar.

\footnotetext{
${ }^{284}$ Vid. ALFARO ÁGUILA-REAL, J.: "Lecciones: las prestaciones accesorias". Blog Almacén de Derecho, 7 octubre 2015 (como entrada basada en: ALFARO ÁGUILA-REAL, J.: "Prestaciones accesorias", en GARRIDO MELERO, M.; FUGARDO ESTIVILL, J. M. ${ }^{\text {a }}$ (coords.). El patrimonio familiar, profesional y empresarial. Sus protocolos. T. IV (Ordenamiento jurídico y empresa familiar. El protocolo familiar). Barcelona: Bosch, 2005, pp. 433-480), quien especifica que, en tal caso, el contrato laboral sería común o, en su caso, de alta dirección. Sigue este autor especificando que si la socia "controla la sociedad porque ostenta una participación elevada en el capital social [...], habrá que considerar que existe un contrato mercantil de arrendamiento de servicios entre la sociedad y [la socia]".

${ }^{285}$ Vid. MARTÍNEZ NADAL, A.: Las prestaciones accesorias..., op. cit., p. 11.

${ }^{286}$ En matización de ALFARO ÁGUILA-REAL, J.: "Lecciones...", op. cit.

${ }^{287}$ Las palabras entrecomilladas son de autoría de BERNING PRIETO, A. D.: "Prestaciones accesorias...", op. cit. También destacaría que las prestaciones accesorias no forman parte del capital social sino del patrimonio social ALFARO ÁGUILA-REAL, J.: "Lecciones...", op. cit.

288 Vid. MARTÍNEZ NADAL, A.: Las prestaciones accesorias..., op. cit., p. 11. 


\section{6. ¿EMPRENDIMIENTO COLECTIVO CON UNA PROPUESTA DE ENTIDAD DE RESPONSABILIDAD LIMITADA FLEXIBLE Y SIMPLIFICADA? ${ }^{289}$}

Fuera de los contornos propios de la economía social, por una entidad ${ }^{290}$ con personalidad jurídica propia y con responsabilidad limitada de las socias, con simplicidad y flexibilidad contractual, sin capital mínimo legal y sin necesidad de aportaciones de capital, apuesta la Comisión de Naciones Unidas para el Derecho Mercantil Internacional (en siglas en idioma español, se recuerda, CNUDMI). Su apuesta se viene desenvolviendo en las tareas que, desde febrero de 2014, viene desplegando el Grupo de Trabajo I sobre las micro, las pequeñas y las medianas empresas, y que están desembocando en la preparación de una Guía Legislativa sobre una entidad de responsabilidad limitada (ERL-CNUDMI).

El empeño de esta Comisión de Naciones Unidas es el diseño de una forma jurídica apta para el emprendimiento colectivo de escasos recursos financieros, como escasos suelen ser los recursos económicos (y también en muchos casos educativos) de las mujeres que trabajan en el sector de los cuidados y el hogar. Proyecta configurar una entidad mercantil caracterizada por la simplicidad, la libertad, la autonomía y la flexibilidad para dar identidad y visibilidad a las micro y pequeñas empresas con seguridad y formalidad y, por tanto, con plena personalidad jurídica y con responsabilidad limitada. Sirve tanto para el emprendimiento individual (con una sociedad unipersonal) como el colectivo (con una sociedad pluripersonal), con o sin ánimo de lucro, y con una "estructura menos rígida y menos formalista basada en las verdaderas necesidades y expectativas de $1[\mathrm{a}] \mathrm{s}$ empresari[a]s".

\footnotetext{
${ }^{289}$ Acerca de la propuesta de entidad de responsabilidad simplificada que plantea la CNUDMI tuvimos ocasión de escribir con mayor grado de detenimiento en nuestro siguiente capítulo de libro: GARCÍA MANDALONIZ, M.: "Fomentando la formalización...", op. cit., pp. 155-164. Las reflexiones allí plasmadas conforman la base de las que ahora se vierten en este epígrafe, tanto en el texto principal como en las notas a pie de página.

${ }^{290}$ La CNUDMI en la propuesta de Guía Legislativa sobre una entidad de responsabilidad limitada (ERLCNUDMI) omite con intención el término "sociedad" y emplea con consciencia -desde el nomen iuris-el término neutro de "entidad" para visibilizar la separación que pretende con el vigente derecho societario. Bajo el principio de "neutralidad terminológica" que busca consolidar no habría "sociedades" sino "entidades", no habría "socios" sino "miembros". Procedente del vocablo latino "entitas", una "entidad" es -en el cuarto significado que la Real Academia Española de la Lengua ofrece- un "ente o ser" y -en el primero de los significados ofrecidos- una "colectividad considerada como unidad y, en especial, cualquier corporación, compañía o institución, tomada como persona jurídica”. Entidad de naturaleza societaria es la compañía mercantil; entidad de naturaleza no societaria sería la ERL-CNUDMI. Desconectado de los vastos contornos del vigente derecho de sociedades se diseñaría, entonces, un derecho de entidades de responsabilidad limitada. Serían dos compartimentos estancos que correrían paralelos, aunque creemos que el derecho de entidades simplificadas guardaría reminiscencias del derecho de sociedades del que trataría de desprenderse para independizarse, y al que tendría que retornar de modo supletorio para cubrir sus lagunas. En cualquier caso, el propuesto por la CNUDMI sería un derecho de las entidades empresariales de constitución y organización simplificada. La ERL-CNUDMI gozaría de personalidad jurídica y de responsabilidad limitada, tendría objeto social general y, en función de la libertad contractual, tendría o no ánimo de lucro, capital social y aportes patrimoniales; conforme en el texto principal tendremos ocasión de reiterar.
} 


\subsection{Con personalidad jurídica y responsabilidad limitada.}

Bajo el propósito principal de incrementar las cotas de formalización del emprendimiento, desde nuestro enfoque, femenino, percibe la CNUDMI la necesidad y conveniencia de configurar un marco jurídico-societario ágil y maleable. Una sociedad suficientemente flexible y simplificada como la planteada por Naciones Unidas adquiriría su plena personalidad jurídica para actuar en el tráfico mercantil. La sociedad mercantil simplificada tendría personalidad jurídica y actuaría con responsabilidad limitada. Sabido es que la necesidad ampliamente sentida en el tráfico mercantil que aspira cubrirse con la configuración de una persona jurídica es la actuación con responsabilidad limitada por parte de quienes deciden dar inicio a una actividad empresarial y quieren resguardar su patrimonio personal. Si se pretende (como el proyecto de Guía Legislativa de la ERL-CNUDMI pretende) que un nuevo régimen jurídico resulte presto, útil y seguro para las emprendedoras, rasgo inherente del planteamiento de la figura jurídica simplificada ha de ser la responsabilidad limitada. La nueva forma jurídica propuesta goza de una arquitectura societaria sin pérdida ni de la personalidad jurídica ni de la responsabilidad limitada y con ganancia de la simplicidad y la flexibilidad.

\subsection{Sin capital social mínimo legal.}

El planteamiento de una forma jurídica empresarial flexible y sencilla ${ }^{291}$ se combina con la no exigencia de capital mínimo legal para favorecer la creación de las empresas y, con ello, el espíritu empresarial. La simplificación de la forma jurídica implica la derogación del requisito de capital mínimo o, cuando menos, la reducción de su cuantía a una "suma simbólica"292.

Habiéndose propuesto la no exigencia legal de un capital mínimo para la existencia y subsistencia de la planteada sociedad simplificada, no habría necesidad de realizar aportaciones de capital. Las socias no vendrían obligadas a efectuar aportación patrimonial alguna. A su libre decisión quedaría aportar o no y, en caso de aportar, la forma, el tiempo y el valor de esa aportación. En dinero en efectivo, en créditos, en bienes materiales o inmateriales, en ejecución de obras, servicios prestados o a prestar podrían consistir, en un listado no tasado, las aportaciones decididas para las que no se requeriría, salvo acuerdo expreso en contrario, valoración mediante un informe de experto independiente. Quisiéramos enfatizar que en servicios prestados o a prestar podrían consistir las aportaciones de las socias. Siendo así, esta sociedad esbozada desde el ámbito internacional sería de utilidad para las trabajadoras del hogar en el caso

\footnotetext{
${ }^{291}$ La Recomendación no 57 (ap. C, párrafos 240 a 243) de la Nota de la Secretaría de la CNUDMI de 10 de abril de 2018 enfoca las formas jurídicas empresariales flexibles como complemento del registro electrónico empresarial.

292 Párrafos 240, 241 y 242 de la Nota citada supra en la nota a pie de página previa. ISSN: 2174-6419 Lex Social, vol. 9, núm. 2 (2019)
} 
de que esas aportaciones en forma de servicios prestados o a prestar pudieran prestarse no solo a favor de la sociedad sino de terceras personas.

El clásico principio de la libre autonomía de la voluntad de las partes sería el que regiría tanto para la aportación como para la distribución de las ganancias que, en su caso, consiguiera la sociedad simplificada durante el curso de sus negocios. En el planteamiento del proyecto de Guía Legislativa, el común acuerdo es el principio supremo y, a falta de él, la participación en igualdad en el patrimonio y en la distribución de las utilidades, pudiéndose aprobar por acuerdo de los miembros la cantidad, el tiempo y la forma (en efectivo o en bienes) de la distribución de los beneficios $^{293}$. Una norma imperativa existiría para la protección de los terceros, empero. Para su máxima protección contra una posible distribución indebida de utilidades, no podría haber distribución en caso de insolvencia o de balance negativo. A la sociedad simplificada planteada no se le permitiría distribuir utilidades si, al hacer la distribución, no estuviera en condiciones de pagar las deudas en el momento de su vencimiento o si el activo total fuese inferior a la suma del total del pasivo ${ }^{294}$. De contrariarse esta prohibición, la obligación de devolución del monto indebidamente distribuido recaería sobre las socias que lo hubieran percibido ${ }^{295}$. Una doble matización incorpora el proyecto de Guía Legislativa, acto seguido: ni el pago de una remuneración razonable por los servicios prestados ni la suma adeudada de buena fe por la entidad a alguna de sus socias podría considerarse distribución de utilidades y, en consecuencia, no sería de aplicación la citada regla de la devolución.

El marco jurídico propuesto por Naciones Unidas y aquí meramente bosquejado tiene como sustento la flexibilidad y la sencillez en la organización societaria para responder a las particularidades y los requerimientos de las empresas emergentes. Se resume que las características esenciales de la reforma societaria propuesta serían la personalidad jurídica y la responsabilidad limitada sin capital social mínimo legal. Al principio de sin capital mínimo legal le acompañarían el de sin efectiva aportación patrimonial y el de reforzamiento de la responsabilidad de las administradoras para una adecuada tutela de los acreedores. En suma y en palabras de este organismo internacional ${ }^{296}$ : "Transparencia y rendición de cuentas, formas jurídicas flexibles [...], reducción o eliminación de los requisitos de capital mínimo [...] y una legislación clara”.

Con una legislación clara se perseguiría encauzar la iniciativa empresarial. Sería una legislación defensora y fortalecedora de los diversos sectores empresariales, también de los más tradicionales. Con los caracteres expresados quizás pudiera ser de utilidad para las emprendedoras que decidieran abrirse camino de forma colectiva en el sector

\footnotetext{
${ }^{293}$ Recomendación $n^{\circ} 19$ del proyecto de Guía Legislativa sobre la entidad de responsabilidad limitada de la CNUDMI, de 25 de julio de 2016, p. 10 (A/CN.9/WG.I/WP.99/Add.1)

${ }^{294}$ Recomendación no 20 (pp. 10-11).

${ }^{295}$ En la Recomendación n ${ }^{\circ} 21$ del proyecto (pp. 11-12).

${ }^{296}$ Nota de la Secretaría de CNUDMI sobre las mejores prácticas de inscripción registral de empresas de 5 de septiembre de 2014, p. 25. 
doméstico, cuando esta forma societaria simplificada sea aprobada en el ámbito internacional e instaurada en nuestro ordenamiento interno. Hasta entonces, las trabajadoras del hogar cuentan con la cooperativa de trabajo asociado y la sociedad limitada laboral para transformarse en emprendedoras del hogar.

\section{EMPODERAMIENTO ECONÓMICO DE LA EMPRENDEDORA DEL HOGAR PARA UN AUTOEMPLEO DECENTE.}

Además de configurar un sistema jurídico capaz de avivar el emprendimiento colectivo femenino tradicional, con más incentivos fiscales y laborales, sería conveniente fortalecer un ecosistema de información, formación, orientación y tutorización para la viabilidad y la productividad de los emprendimientos puestos en marcha por parte de las trabajadoras del hogar. Se precisa asistencia técnica, mentoring y acompañamiento a lo largo del proceso de constitución societaria y durante la vida empresarial. Se requiere formación para el fomento de la emancipación en el trabajo por medio de un trabajo cooperativo. Para ello, habría que configurar una cadena de valor para relanzar el emprendimiento colectivo y social, por medio de cooperativas y sociedades laborales, para la inclusión de los colectivos vulnerables y para el (auto)empleo decente y de calidad en el sector doméstico.

Hay iniciativas de cooperativas de trabajo (de iniciativa social) que apoyan la creación de cooperativas de trabajo asociado en este ámbito ${ }^{297}$. Actúan a modo de "red de mentoras", con expertas que proporcionan asesoramiento técnico en los procesos de constitución y de funcionamiento de las cooperativas de trabajo en el servicio doméstico $^{298}$. Hay iniciativas, pero hay que incitar más y apoyarlas institucionalmente.

De cara a potenciar las potencialidades de las empleadas del hogar, las emprendedoras del hogar requieren una atención y un apoyo específico. Requieren previamente información. A tratar de proporcionar información sobre la regulación legal de los distintos formatos societarios más o menos aptos para el emprendimiento colectivo, dentro y fuera de la economía social, se han dirigido las páginas del presente texto divulgativo. Si los interrogantes que aquí han sido planteados han sido bien contestados, habrán sido interrogantes esfumados. Otros interrogantes que no han podido ser ni trazados ni resueltos aparecerán o subsistirán entre las trabajadoras del hogar. Quienes 297 Como tuvimos ocasión de adelantar supra en la nota a pie de página no 16 , “Abierto Hasta el
Amanecer, S. Coop." es una cooperativa de trabajo [de iniciativa social] que se constituyó en el 2002"
con sede en Madrid. "Uno de los proyectos que desarrolla es el asesoramiento en procesos de constitución
de empresas cooperativas, en especial, cooperativas de trabajo en el Servicio Doméstico". Ha asesorado y
ha ayudado a empleadas del hogar en la creación de cooperativas de trabajo asociado.
298 Otro ejemplo más es "Work-Lan Bizcaia", como "iniciativa para impulsar la creación de cooperativas
para las empleadas del hogar, gracias al asesoramiento técnico recibido de la experiencia desarrollada en
Madrid, a través de la cooperativa abierto hasta el amanecer (AHA)". Consúltese, de nuevo, supra la nota
a pie de página $\mathrm{n}^{\circ} 16$.
ISSN: $2174-6419$
Lex Social, vol. 9, núm. 2 (2019) 
en el futuro se decidan a emprender con la información y el asesoramiento de quienes en el pasado se decidieron podrán incrementar su visibilidad.

Es "visibilizar para transformar"299. Es transformar para visibilizar. Es visibilización junto con transformación para el empoderamiento. El empoderamiento económico como finalidad última del autoempleo colectivo como salida laboral. El autoempleo colectivo, como el empleo, ha de ser decente. Se insta un trabajo doméstico decente. Para la aceptación de este concepto de trabajo decente de las trabajadoras domésticas falta la ratificación ${ }^{300}$-reiteramos y criticamos- por España del Convenio de la OIT número 189, adoptado en la conferencia de 16 de junio de 2011 y complementado con la Recomendación 201. Si se ratificara por nuestro país, las trabajadoras domésticas disfrutarían aquí "de condiciones no menos favorables que las condiciones aplicables a 1[a]s trabajador[a]s en general con respecto a la protección de la Seguridad Social", en el mandato del primer párrafo del artículo 14 del Convenio. Disfrutarían, por ende, de protección por desempleo todas las empleadas del hogar y no solo las emprendedoras del hogar que constituyeran una entidad de economía social bajo el formato de la cooperativa o de la sociedad limitada laboral. Si se ratificara, nuestro país, como miembro, podría tener "debidamente en cuenta las características específicas del trabajo doméstico" y aplicar las medidas de manera progresiva, en consulta con las organizaciones representativas de empleadoras y trabajadoras; en la disposición combinada de los párrafos primero y segundo de aquel precepto. Su necesaria ratificación supondría un "paso más en pos de la dignificación de las condiciones de trabajo" ${ }^{301}$ del colectivo de las trabajadoras del hogar. Cerremos este trabajo de investigación con la confianza en la ratificación futura para la esperanza en la dignificación del trabajo doméstico.

\footnotetext{
${ }^{299}$ Como lema de SEDOAC en su primer congreso sobre el empleo del hogar y cuidados, el 1 y 2 de octubre de 2016; según tuvimos ocasión de apuntar al inicio de este estudio.

${ }^{300}$ Hay ratificación, en cambio, de veinticinco Estados, seis de ellos de la Unión Europea: Alemania, Bélgica, Finlandia, Irlanda, Italia y Portugal.

${ }^{301}$ En palabras de SANDE PÉREZ-BEDMAR, M. DE: “La relación laboral especial...”, op. cit., p. 154; referenciando a: FEDERACIÓN DE SERVICIOS DE LA UGT: Características, problemática..., op. cit. ISSN: $2174-6419$ Lex Social, vol. 9, núm. 2 (2019)
} 


\section{BIBLIOGRAFÍA:}

ALFARO ÁGUILA-REAL, J.: "Prestaciones accesorias", en GARRIDO MELERO, M.; FUGARDO ESTIVILL, J. M. ${ }^{\text {a }}$ (coords.). El patrimonio familiar, profesional y empresarial. Sus protocolos. T. IV (Ordenamiento jurídico y empresa familiar. El protocolo familiar). Barcelona: Bosch, 2005.

_ “Lecciones: las prestaciones accesorias". Blog Almacén de Derecho, 7 octubre 2015.

ALONSO SOTO, F.: "Las cooperativas como protagonistas de la economía social". Estudios cooperativos, ${ }^{\circ}$ 53, 1985.

__Ensayos sobre la Ley de Cooperativas. Madrid: UNED, 1990.

ARGUDO PÉRIZ, J. L.: “Las cooperativas sin ánimo de lucro: ¿vuelta a los orígenes o respuesta a nuevas necesidades sociales?". GEZKI, n 3, 2007.

BERNING PRIETO, A. D.: "Prestaciones accesorias en la sociedad de responsabilidad limitada". Noticias jurídicas, 1 febrero 2014.

BROSETA PONT, M.; MARTÍNEZ SANZ, F.: Manual de Derecho mercantil. 25 $5^{\mathrm{a}}$ ed., Vol. I, 2018.

CHAVES ÁVILA, R.; MONZÓN CAMPOS, J. L.: "La economía social ante los paradigmas económicos emergentes: innovación social, economía colaborativa, economía circular, responsabilidad social empresarial, economía del bien común, empresa social y economía solidaria”. Revista de Economía Pública, Social y Cooperativa, $\mathrm{n}^{\circ}$ 93, agosto 2018.

FEDERACIÓN DE SERVICIOS DE LA UGT: Características, problemática y propuestas de reforma del sector del servicio doméstico en España. Noviembre 2005.

FOLGADO, L.: “¿Qué protección tienen los socios trabajadores de las cooperativas ante una crisis empresarial?". Blog Fevecta, 11 marzo 2019.

GARCÍA MANDALONIZ, M.: "El cuestionado sentido del régimen jurídico del capital social", en HIERRO ANIBARRO, S. (dir.), Simplificar el derecho de sociedades. Madrid: Marcial Pons, 2010.

— "Naturaleza jurídica del microcrédito y caracterización societaria de las instituciones microfinancieras". Cuadernos de la Cátedra Garrigues, vol. .3, junio 2015.

_ "Fomentando la formalización del emprendimiento femenino con un registro electrónico de empresas y una entidad de responsabilidad limitada simplificada", en BLÁZQUEZ AGUDO, E. M.: Los ODS como punto de partida para el fomento de la calidad del empleo femenino. Madrid: Dykinson, 2018. 
GARCÍA RUIZ, E.: "El régimen societario de las sociedades laborales en la nueva Ley 44/2015, de 14 de octubre, de sociedades laborales y participadas". REVESCO, n 123 , primer cuatrimestre 2017.

GÓMEZ-CALCERRADA GASCÓN, J. L.: La cooperativa de trabajo. Barcelona: CEAC, 1983.

GÓMEZ CALERO, J.: "Sobre la "mercantilidad" de las cooperativas". Revista de Derecho Mercantil, n 137, julio-septiembre 1975.

JORDÁ GARCÍA, R.: "Empresas de economía social y constitución telemática de sociedades “, en PARDO LÓPEZ, M. ${ }^{\mathrm{a}}$ M.; GÓMEZ MANRESA, M. ${ }^{\mathrm{a}}$ F.: Economía social y derecho. Problemas jurídicos actuales de las empresas de economía social. Granada: Comares, 2013.

LÓPEZ GANDÍA, J., Las relaciones laborales especiales. Albacete: Bomarzo, 2008.

LLOBREGAT HURTADO, M. a L.: "Reflexiones sobre el régimen jurídico de las sociedades anónimas laborales y las cooperativas de trabajo asociado". CIRIEC España. Revista Jurídica de Economía Social y Cooperativa, ${ }^{\circ}{ }^{8}$, 1996.

_ "Régimen económico de las sociedades cooperativas en el marco de la nueva Ley General de Cooperativas de 16 de julio de 1999 (BOE de 17 de julio)". Revista de Derecho de Sociedades, no 13, 1999.

MARTÍNEZ ETXEBERRÍA, G.: La aplicación efectiva de los valores cooperativos. Madrid: Dykinson, 2018.

MARTÍNEZ NADAL, A.: Las prestaciones accesorias en la sociedad de responsabilidad limitada. Barcelona: Bosch, septiembre 1997.

MORILLAS JARILLO, M. ${ }^{a}$ J.: "La nueva regulación estatal de las sociedades cooperativas". Derecho de los Negocios, n 111, año 10, 1999.

_ "El ámbito de aplicación de las leyes de sociedades cooperativas", en Derecho de sociedades: libro homenaje al profesor Fernando Sánchez Calero. McGraw-Hill Interamericana de España, vol. 4, 2002.

__ Las sociedades cooperativas. Madrid: Iustel, 2008.

MORILlAS JARILlO, M. J.; FELIÚ REY, M.: Curso de cooperativas. $3^{\mathrm{a}}$ ed., Madrid: Tecnos, 2018.

MORILLO, M.: "Dos monedas sociales para favorecer una economía alternativa". El País Digital, 3 abril 2018.

PANIAGUA ZURERA, M.: "Las sociedades laborales ante el Anteproyecto de Ley del nuevo Código mercantil", en MORILLAS JARILLO, M. (et al.) (dirs.): Estudios sobre 
el futuro Código mercantil: libro homenaje al profesor Rafael Illescas Ortiz. Getafe: Universidad Carlos III de Madrid, 2015.

PANIZO ROBLES, J. A.: "La Seguridad Social de los socios de las sociedades laborales y participadas. (Con ocasión de la Ley 44/2015, de 14 de octubre)". CEFLaboral Social, octubre 2015.

PORTELLANO DÍEZ, P.: "El sistema de clases en la Ley de Cooperativas: un alegato a favor de la simplicidad legal". Revista de Derecho de Sociedades, n 19, 2002.

SÁNCHEZ CALERO, F.: "Los conceptos de sociedad y de empresa en la Ley de Cooperativas", en Libro homenaje a Ramón M. ${ }^{a}$ Roca Sastre. Vol. III, Madrid: Junta de Decanos de los Colegios Notariales, 1977.

SÁNCHEZ CALERO, F.; OLIVENCIA, M.: "Relaciones del régimen jurídico de las sociedades mercantiles y de las sociedades cooperativas", en El cooperativismo de la coyuntura española actual. Anales de moral social y económica. Vol. 6, Madrid: Centro de Estudios Sociales de la Santa Cruz del Valle de los Caídos, 1964.

SANDE PÉREZ-BEDMAR, M. DE, "La relación laboral especial de los empleados de hogar: aspectos laborales y de Seguridad Social". Revista Jurídica de la Universidad Autónoma de Madrid, $\mathrm{n}^{\circ}$ 23, 2011-I.

SENDIN BLÁZQUEZ, A.: El régimen especial de la Seguridad Social de empleados de hogar: cuestiones sobre su integración en el régimen general de la misma. Ministerio de Trabajo y Asuntos Sociales, diciembre 2006.

SUBEBIOLA GARBIZU, I.: "Régimen tributario de las sociedades laborales". Revista Vasca de Economía Social, n 10, 2013.

_ "Beneficios fiscales de las sociedades laborales en la Ley 44/2015, de 14 de octubre, de sociedades laborales y participadas". Revista Jurídica de los derechos sociales. Lex Social, vol. 7, nº 2, julio-diciembre 2017.

VALPUESTA GASTAMIZA, E. M.; BARBERENA BELZUNCE, I: Las sociedades laborales: aspectos societarios, laborales y fiscales. Pamplona: Aranzadi, 1998.

VICENT CHULIÁ, F.: "Las empresas mutualistas y el derecho mercantil en el ordenamiento español”. Revista Crítica de Derecho Inmobiliario, año 52, no 512, enerofebrero 1976.

_ "Las empresas mutualísticas", en BROSETA PONT, M.: Manual de derecho mercantil. $4^{\mathrm{a}}$ ed., Madrid: Tecnos, 1977.

_ “Los órganos sociales de la cooperativa". Revista Jurídica de Cataluña, vol. 77, n 1, 1978. 
_ "La asamblea general de la cooperativa". Revista Jurídica de Cataluña, vol. 77, n 2, 1978.

_ "Cooperativismo y economía social”, Boletín de la Dirección General de Cooperativas del Ministerio de Trabajo y Seguridad Social, noviembre 1984.

"La Ley 27/1999, de 16 de julio, de cooperativas estatal", Revista General de Derecho, nº63, 1999.

VIÑUELAS SANZ, M.: Las prestaciones accesorias en la sociedad de responsabilidad limitada. Madrid: Dykinson, 2004. 